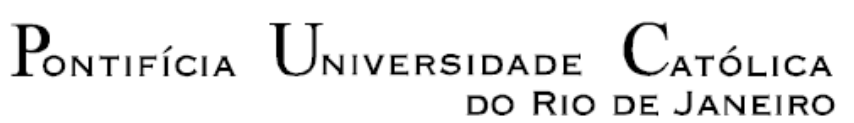

DO RIO DE JANEIRO

Ricardo Hermanson Canela

Uma abordagem crítica sobre a implementação do sistema de gestão ambiental da UTE Macaé

Dissertação de Mestrado

Dissertação apresentada ao Programa de Pós-Graduação em Engenharia Urbana e Ambiental da PUC-Rio como requisito parcial para obtenção do título de Mestre em Engenharia Urbana e Ambiental (opção Profissional).

Orientador: Prof. Celso Romanel

Rio de Janeiro

Dezembro de 2012 


$$
\text { Pontifícia } \text { Universidade Católica }_{\text {Do Rio de Janeiro }}
$$

Ricardo Hermanson Canela

\title{
Uma abordagem crítica sobre a implementação do sistema de gestão ambiental da UTE Macaé
}

\begin{abstract}
Dissertação apresentada como requisito parcial para obtenção do título de Mestre (opção Profissional) pelo Programa de Pós-graduação em Engenharia Urbana e Ambiental da PUC-Rio. Aprovado pela Comissão Examinadora abaixo assinada.
\end{abstract}

\author{
Celso Romanel \\ Presidente / Orientador \\ Departamento de Engenharia Civil - PUC-Rio \\ Ana Cristina Malheiros Gonçalves Carvalho \\ PUC-Rio \\ Antonio Roberto Martins Barboza de Oliveira \\ PUC-Rio
}

Ana Ghislane Henriques Pereira van Elk

Neise Ribeiro Vieira

Prof. José Eugenio Leal Coordenador Setorial de Pós-Graduação do Centro Técnico Científico - PUC-Rio

Rio de Janeiro, 19 de dezembro de 2012 
Todos os direitos reservados. É proibida a reprodução total ou parcial do trabalho sem autorização da universidade, do autor e do orientador.

\section{Ricardo Hermanson Canela}

Graduou-se em Engenharia Civil pela EEVR-FOA (Escola de Engenharia Civil de Volta Redonda na Fundação Oswaldo Aranha, em 1994),

Ficha Catalográfica

Canela, Ricardo Hermanson

Uma abordagem crítica sobre a implementação do sistema de gestão ambiental da UTE Macaé / Ricardo Hermanson Canela; orientador: Celso Romanel. - 2012.

$141 \mathrm{f.} ; 30 \mathrm{~cm}$

Dissertação (mestrado) - Pontifícia Universidade Católica do Rio de Janeiro, Departamento de Engenharia Civil, 2012.

Inclui bibliografia

1. Engenharia civil - Teses. 2. Meio ambiente. 3. Saúde e segurança. 4. Gestão sustentável. 5. SMS no gerenciamento de projeto. I. Romanel, Celso. II. Pontifícia Universidade Católica do Rio de Janeiro. Departamento de Engenharia Civil. III. Título. 
A todos que buscam um desenvolvimento sustentável de maneira inteligente e eficaz. 


\section{Agradecimentos}

As pessoas citadas abaixo colaboraram de alguma forma para a concretização deste trabalho, seja diretamente ou indiretamente.

- Professores Ana Cristina Malheiros G. Carvalho e Celso Romanel, obrigado pela atenção e pelo tempo cedido na orientação da tese e coordenação de todo o curso.

- Paula Elanoy, principalmente pela atenção a mim dispensada durante o curso de Mestrado em Engenharia Urbana e Ambiental.

- Todos os professores do departamento de engenharia civil, são eles: Araruna (CIV), Vargas (CIV), Antônio Roberto (CIV).

- Ao engenheiro e professor Hubmaier Andrade, pela confiança e por suas sugestões na dissertação, bem como para todo o departamento de SMS da El Paso.

- Aos gestores Ivo Neves e Carlos Roberto Coutinho, pelas considerações e revisões dos conceitos por mim aplicados na dissertação.

E por último e mais importante, a minha filha, minha esposa, minha mãe e meu pai, ainda tão presentes nos importantes momentos da minha vida. 


\section{Resumo}

Canela, Ricardo Hermanson; Romanel, Celso (Orientador). Uma abordagem crítica sobre a implementação do sistema de gestão ambiental da UTE Macaé. Rio de Janeiro, 2012, 141p. Dissertação de Mestrado - Departamento de Engenharia Civil, Pontifícia Universidade Católica do Rio de Janeiro.

O presente trabalho apresenta a importância da Termoeletricidade a gás para o País, abordando a caracterização do setor elétrico brasileiro, as especificidades e seus impactos. Demonstra a importância da gestão ambiental e a conceitua em diversos cenários. São abordados os aspectos legais e institucionais, inerentes ao licenciamento específico para unidades geradoras. É feita a caracterização da UTE Macaé, objeto de estudo da gestão ambiental. A análise crítica da implementação do sistema de gestão ambiental identificou diversas lições aprendidas nos diversos períodos do empreendimento.

\section{Palavras-chave}

Meio ambiente; saúde e segurança; gestão sustentável; SMS no gerenciamento de projeto. 


\section{Extended Abstract}

Canela, Ricardo Hermanson; Romanel, Celso (Advisor). A critical approach to the implementation of the environmental management system of Macae Power Plant. Rio de Janeiro, 2012. 141p. MSc Dissertation - Departamento de Engenharia Civil, Pontifícia Universidade Católica do Rio de Janeiro.

The present work aims the importance of gas thermoelectricity for the country, considering the Brazilian electrical sector characterization, specificities and their impacts.

Demonstrate the importance of environmental management and concepts it in several scenarios. Issues regarding legal and institutional aspects, mainly permitting process for generator units.

It was presented a characterization of Macae Power Plant, the object of our environmental management studies. A critical approach to the implementation of the environmental management system of UTE Macaé has identified several lessons learned during different project periods.

We have the historical evolution of thermoelectrical plants in Brazil in order to understand the type of energy matrix available. In 2001, the country faced problems due lack of rain when the whole Country was supplied by Hydro plants needed to save energy. The lack of energy tied the Country development. Immediately the Brazilian government take action with the using a gas from Bolivia-Brazil pipeline putting emergencial gas power plants as a fast track project In order to implement an alternative energy source based on natural gas, it was considered the lesser impact alternative source and more reliable for the power plants in case of lack of rain that supplies the Hydro plants.

The characterization of Brazilian energy sector, verifying the main characteristics and specificities of thermoelectrical plants and their environmental impacts, are the most critical paths in order to implement a projects. To develop any project or specific projects such power plants it is necessary to understand the 
culture and specific environmental and social issues in order to avoid any impact to the project.

Other specifities regarding hydro plants and gas power plants such environmental and social impacts generate by each specific type of generation was brought up.

During the development of this work is highlighted the environmental management concept analyzing the national and international guidelines regarding environmental management, some of them are already well accepted however all the organizations should be aware that not just a good recognized management system will guarantee an excellent results of environmental, health , safety and production. Knowledge and commitment is required from everyone in the organization.

It is impossible not mention and discuss in a work like that, the legal and institutional aspects related with natural gas power plant emphasizing environmental licensing problems. The Brazilian legislation is pretty new and all the time has some changes that usually can impact the project. During the our case of study UTE Macaé, we were learning together with the environmental agency because this was one of the first gas power plants built in Brazil.

The UTE Macaé - Power Plant our case of study is well characterized with all project details. In the process side there is a good description, energy generation process, basic sources "water and natural gas “.

Operational and project characteristics is aligned with all information needed to understand the project are described in this work.

Considering our case of study UTE Macaé we went through all the experience and each specific area including: Environmental management system, mitigation programs and a really huge monitoring program that covers whatever deviation that could appear due any operation.

With all the experiences before us established a lessons learned to be shared with you in order to avoid future environmental, social or economic impacts in other Gas power plant implementation worldwide. It is good to be clear 
that two separated phases area explained and both are very important, construction and operation.

The Environmental Management analysis of Macaé Power Plant was identified in the previous paragraphs and concluded with the lessons learned giving a really good supporting a critical approach of implementation of the environmental management system of UTE Macaé.

Create a good interaction between competent project manager and integrated project team. Define on time with good anticipation HSE resources necessaries as following: people, budget and time.

\section{Keywords}

Environmental; health and safety; sustainable management system; HSE considered in project management. 


\section{SUMÁRIO}

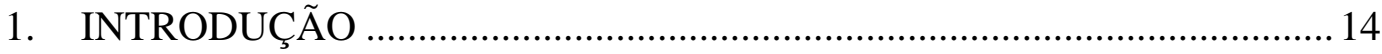

1.1. Objetivos e Estrutura da Dissertação ................................................... 14

1.2. Histórico da Evolução de Usinas Térmicas no Brasil................................ 16

2. CARACTERIZAÇÃO GERAL DO SETOR ELÉTRICO ...............................20

2.1. Histórico do Setor Elétrico Brasileiro......................................................... 20

2.2. Especificidades das Hidroelétricas no Brasil.............................................2 24

2.3. Impactos sócio-ambientais gerados pelas hidrelétricas ..............................28

2.4. Especificidades das Usinas Termelétricas a Gás Natural ...........................30

2.5. Impactos sócio-ambientais nas térmicas a gás natural............................... 41

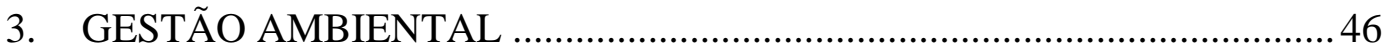

3.1. Conceito de gestão ambiental ................................................................ 46

3.2. A Conscientização Ambiental e as Normas ISO 14000 ............................ 48

3.3. Dos Benefícios do Sistema de Gestão Ambiental...................................... 51

3.4. Fatores relacionados à Implementação do Sistema de Gestão

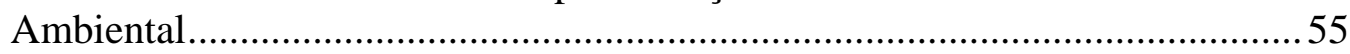

3.5. Evolução e repercussão no ambiente industrial .........................................57

3.6. A questão ambiental sob o enfoque econômico........................................59

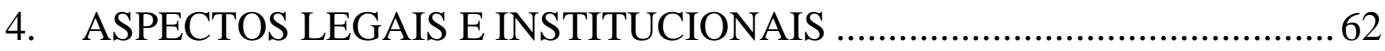

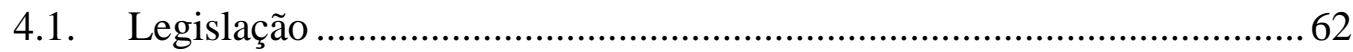

4.2. O Licenciamento Ambiental .................................................................64

4.3. Licenciamento Ambiental de Usinas Térmicas .......................................... 68

5. CARACTERIZAÇÃO TÉCNICA DA USINA TÉRMICA MACAÉ..............72

5.1. Introdução e caracterização do Empreendimento ...................................... 72

5.2. Descrição do processo de geração …………………………………….....75

5.3. Caracterização dos insumos básicos .......................................................76

5.3.1. Gás Natural ................................................................................ 76

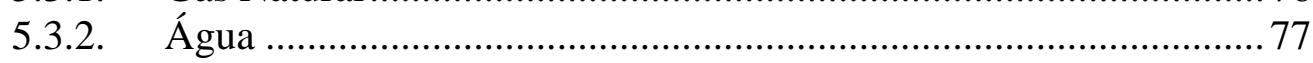

5.4. Caracaterísticas operacionais e de projeto ……………………………..... 78

5.4.1. Grupo Turbina - Gerador ............................................................. 78

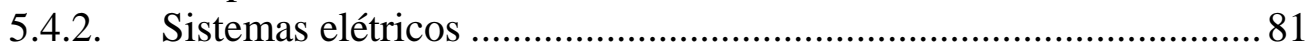

5.4.3. Sistemas Auxiliares do Grupo Turbina - Gerador .............................. 82

5.4.4. Sistema e Equipamentos de Distribuição Elétrica da Usina.............. 84

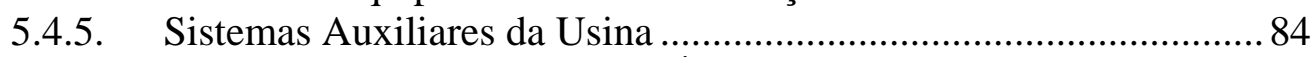

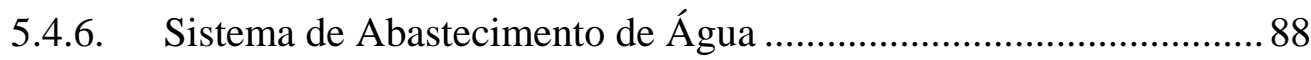

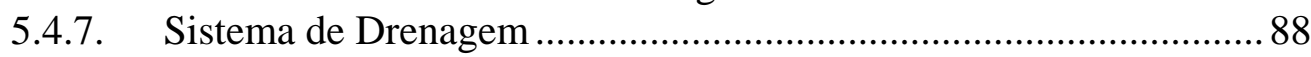

5.4.8. Sistema de Tratamento Sanitário ......................................................... 88

5.4.9. Sistema de Tratamento de Efluentes do Processo ............................ 88

5.4.10. Sistema de Controle de Emissões Atmosféricas ................................ 89

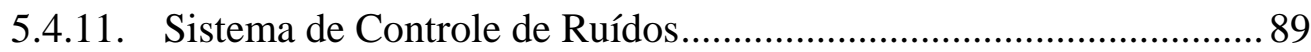

5.4.12. Sistema de Coleta e Disposição Final de Resíduos Sólidos .............. 90 
6. GESTÃO AMBIENTAL DO EMPREENDIMENTO_.................................91

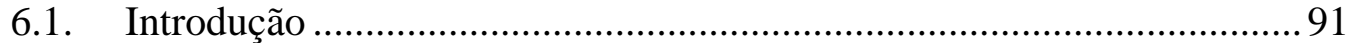

6.2. Estrutura do sistema de gestão ambiental do empreendimento .............. 92

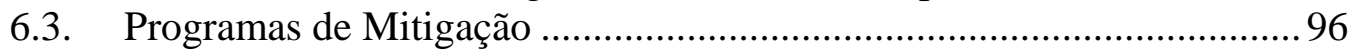

6.3.1. Programa Ambiental de Construção - PAC .................................... 96

6.3.2. Projeto paisagístico e de recomposição da faixa marginal de

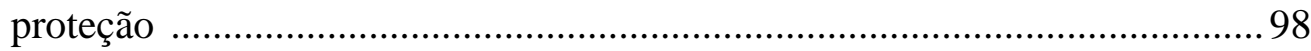

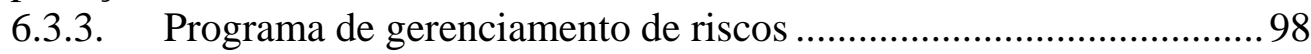

6.3.4. Programa de comunicação social ..................................................101

6.3.5. Programa de contratação e desmobilização de mão de obra .......... 102

6.4. Programas de Monitoramento............................................................... 102

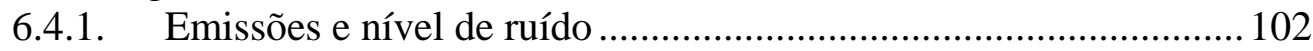

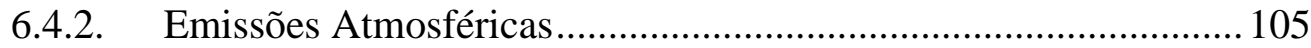

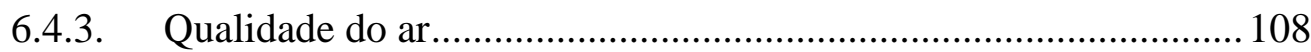

6.4.4. Qualidade da água no rio Macaé .................................................. 111

6.4.5. Qualidade dos efluentes......................................................... 114

6.4.6. Solos e águas subterrâneas ........................................................ 116



6.4.8. Resíduos Sólidos ................................................................... 117

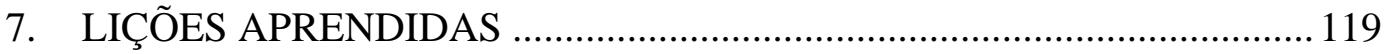

7.1. Lições aprendidas durante a fase da construção da UTE Macaé ........... 119

7.2. Lições Aprendidas durante a fase de operação .....................................124

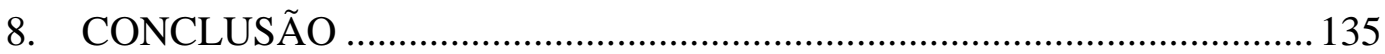

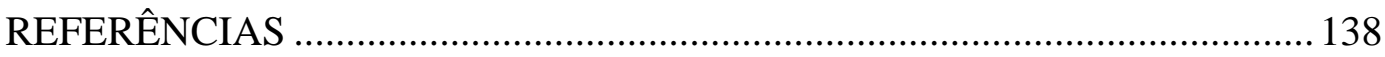




\section{LISTA DE FIGURAS}

Figura 1 - Exemplo de uma turbina em uma usina hidroelétrica .........................226

Figura 2 - Modelo esquemático de Entrada de água em uma Comporta de

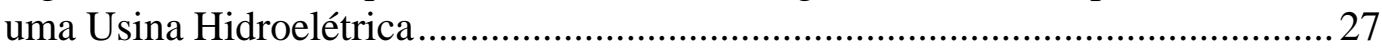

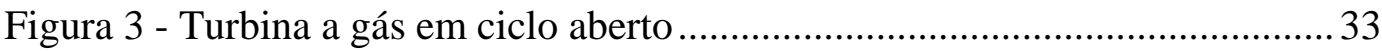

Figura 4 - Turbina a gás em ciclo combinado ........................................................ 34

Figura 5 -Termelétrica a Ciclo Combinado (CCPS) Tipo 1 + 1- em eixo único .. 36

Figura 6 - Fluxograma típico de uma Termoelétrica de Ciclo Combinado

(CCPS) - Tipo 2+1 Fonte: http://www.gasnet.com.br/novo_termeletricas/

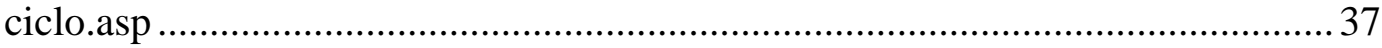

Figura 7 - Arranjo típico de uma Termoelétrica a Ciclo combinado (CCPS) ...... 39

Figura 8 - Poluição aérea e suas conseqüências (Fonte: Lisboa, 2007) ................. 42

Figura 9 - Localização Regional e Foto Aérea Construção 2001............................ 72

Figura 10 - Configuraçâo da transmissâo no sistema interligado sudeste-sul -

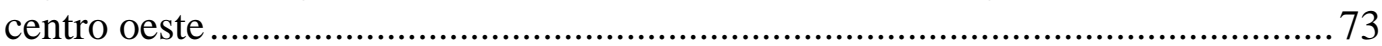



Figura 12 - Layout da usina com devidas identificações - 2002 ......................... 74

Figura 13 - Turbina do tipo GE LM 6000 ........................................................... 80

Figura 14 - Modelo esquemático dos insumos para geração térmica a gas

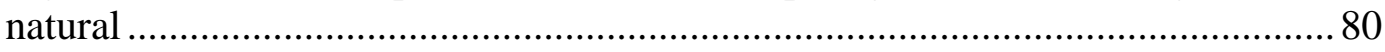

Figura 15 - Arranjo de montagem do sistema de admissão de ar sobre o grupo

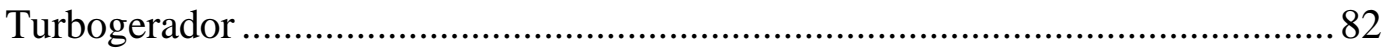

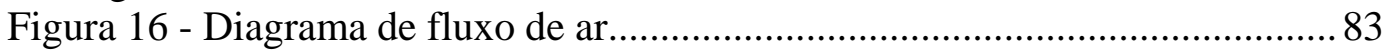

Figura 17 - Estrutura do Sistema de Gestão Ambiental do Empreendimento....... 96

Figura 18 - EMIS: Environmental Health and Safety Management System

(Sistema de Gerenciamento de SMS)............................................................. 132

Figura 19 - SISGIU - Sistema Simplificado de Gestão de Informações da

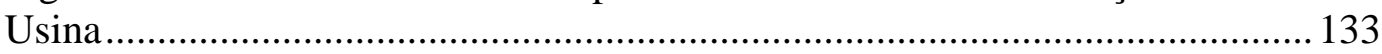

Figura 20 - Treinamentos de Brigada de Emergência ......................................... 133

Figura 21 - Plano de Gerenciamento de Resíduos............................................. 134 


\section{LISTA DE TABELAS}

Tabela 1 - Oferta interna de energia elétrica ..................................................... 19

Tabela 2 - Parque Gerador de energia em Dezembro de 2010 ............................... 24

Tabela 3 - Benefícios da gestão ambiental .......................................................... 54

Tabela 4 - Documentos imprescindíveis ao licenciamento ambiental .................. 70

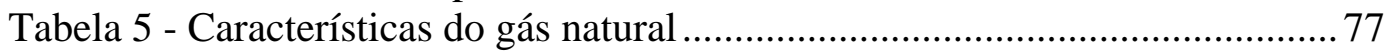

Tabela 6 - Frequencia de Medições e de Coleta de Amostras de Efluentes......... 115

Tabela 7 - Nível de critério de avaliação NCA para ambientes externos, em

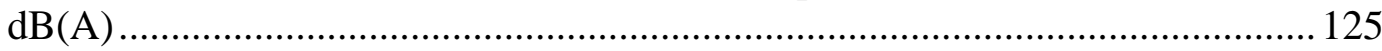




\section{INTRODUÇÃO}

\section{1}

\section{Objetivos e Estrutura da Dissertação}

Os objetivos do presente estudo é, desenvolver uma abordagem crítica da implementação do sistema de Gestão Ambiental da UTE Macaé, durante as fases de implantação e operação da Usina Termelétrica Macaé, UTE Macaé.

Esperando como conclusão final da dissertação sugestões, baseadas nas lições aprendidas durante a implantação do sistema de gestão na UTE Macaé, baseado no alicerce das diretrizes internacionais aplicadas.

A escolha da Usina Termelétrica Macaé, denominada “UTE Macaé”, como objeto desta dissertação se baseou no conhecimento do autor sobre o projeto supracitado, com intuito de apresentar o programa de gestão ambiental, durante a construção, e principalmente na operação de UTE. Esta unidade produz energia utilizando gás natural, uma fonte alternativa de energia.

Neste trabalho são apresentados os mecanismos de implantação e operação da usina termelétrica na região de Macaé, bem como análise dos impactos ambientais e a gestão ambiental necessários para a implantação da unidade em referência.

A metodologia empregada na elaboração desta dissertação é a pesquisa descritiva (LONGARAY et al., 2003), cuja característica básica consiste em descrever, registrar, analisar e interpretar os fenômenos atuais. Esta pesquisa será segmentada em fontes secundárias, ou seja, em dados bibliográficos.

Também será usado a pesquisa bibliográfica, que consiste em reunir informações disponíveis em livros, artigos de periódicos, monografias, dissertações, jornais, revistas, periódicos nacionais, internet e outros materiais que sejam de utilidade na pesquisa Segundo Gil (apud LONGARAY et al., 2003, p. 
87) a "pesquisa bibliográfica é desenvolvida mediante material já elaborado, principalmente livros e artigos científicos”.

Por fim a estrutura do presente estudo se baseia em 7 capítulos mais conclusões e referencias bibliográficas sendo que:

a) O Primeiro capítulo tem por finalidade apresentar considerações sobre os objetivos e metodologias aplicadas na dissertação, assim como a evolução histórica das usinas termelétricas no Brasil.

b) O segundo capítulo busca caracterizar o setor energético no país, verificando as principais características e especificidades das usinas termelétricas e os impactos ambientais decorrentes das mesmas.

c) O terceiro capítulo ressalta o conceito de gestão ambiental, citando as principais diretrizes nacionais e internacionais no âmbito da gestão ambiental.

d) O quarto capítulo, trata dos aspectos legais e institucionais relacionados a implantação de uma usina termelétrica a gás natural, destacando-se ainda a questão do licenciamento ambiental.

e) O quinto capítulo faz um descritivo da caracterização técnica da Usina Termelétrica Macaé. - UTE Macaé

f) O sexto capítulo trata do processo de gestão ambiental aplicado à Usina Termelétrica Macaé. - UTE Macaé

g) O sétimo capítulo apresenta as lições de aprendizado nas diversas fazes do projeto

h) O oitavo capítulo finaliza o projeto através de uma conclusão.

i) Por fim, referencias bibliográficas aplicadas no presente estudo. 


\section{2}

\section{Histórico da Evolução de Usinas Térmicas no Brasil}

As termelétricas movidas a carvão e óleo combustível já existiam no Brasil, mas haviam perdido participação na matriz energética ao longo dos anos. Alguns fatores relacionados por Leite (2007) contribuíram para sua expansão nos últimos anos:

a) Diminuição dos investimentos estatais no setor elétrico no fim do século XX conjugado a um aumento da demanda de energia;

b) Preocupação nacional com o crescimento econômico continuado;

c) Usinas hidrelétricas demandam mais tempo que as térmicas para construção;

d) Países industrializados onde aproveitamentos hidrelétricos não eram possíveis possuíam boa tecnologia térmica disponível; e a

e) Otimização em longo prazo dos recursos hídricos para poupar ou substituir a energia hidrelétrica pela térmica em anos de hidrologia adversa.

Prevendo o colapso físico do sistema elétrico, quando em 1999 os principais reservatórios situados na região Sudeste/Centro-Oeste atingiram níveis muito baixos, o governo federal lançou através do Ministério de Minas e Energia (MME) o Programa Prioritário de Termelétricas (PPT) com o planejamento de construção de 15 usinas movidas a gás. Esse programa esbarrou, entre outros problemas, na dificuldade de aquisição de turbinas no mercado internacional que estava saturado de encomendas. O racionamento de energia ocorreu em junho de 2001 com cotas que deveriam ser cumpridas sob o risco de tarifação diferenciada para os consumos excedentes e cortes de energia se as cotas não fossem respeitadas.

Cabe ressaltar que, até então, a geração termelétrica tinha sido pouco utilizada, por antecipação, para sustentar as reservas hídricas e melhorar os níveis de segurança das usinas hidrelétricas. 
As empresas que investem em usinas termelétricas movidas a gás têm se mostrado como os principais novos compradores para utilização do gás natural. É esperado, conforme planejamento do Governo, que a participação do gás natural na matriz energética brasileira aumente cada vez mais.

Outro fator que impulsionou a utilização de termelétricas a gás foi o acordo Brasil Bolívia de importação de gás assinado em 1992. Definida uma quantidade inicial de 8 milhões de metros cúbicos diários que deveria crescer gradativamente até atingir 16 milhões de metros cúbicos no oitavo ano a partir da operação com opção de compra de 14 milhões adicionais, a Petrobras em conjunto com outras empresas privadas, construiu um gasoduto que comportava transportar os 30 milhões de metros cúbicos desde a Bolívia até Campinas. O Brasil já havia rejeitado esse combustível no passado por saber que estaria dependente desta fonte de energia, cujas reservas próprias do país até então conhecidas não poderiam satisfazer a demanda de uma economia em crescimento.

A compra do gás foi ainda estruturada sob a cláusula take-or-pay que obriga o comprador a pagar pelo gás, usando-o ou não. Sendo assim, precisava-se encontrar usos para o gás natural importado para que a operação do gasoduto fosse economicamente viável.

Houve, então, um incentivo à troca do óleo combustível pelo gás natural e à construção de usinas termelétricas. Logo, as termelétricas ficaram entre a emergência de suprir a falta de energia através do PPT e a necessidade de tornar viável economicamente o gasoduto Brasil-Bolívia.

Leite (2007) ainda comenta que, com a evolução incentivada dos outros tipos de consumo, não se dispõe de gás nem mesmo para atender à demanda mínima das usinas do PPT. Ou seja, se houver a necessidade de que todas as termelétricas funcionem ao mesmo tempo com carga máxima (por conta de um ano seco, por exemplo) provavelmente não haveria gás suficiente para estas.

Fato este que vai mudar em breve, com as recentes descobertas de jazidas de gás no litoral dos estados do Espírito Santo e São Paulo, principalmente nas camadas do pré e pós sal, apontadas através de relatórios feitos pela Petrobras, empresas parceiras e outras concorrentes. 
Segundo a ANEEL, o Brasil possui no total 1.429 usinas de geração de energia elétrica, onde 1.076 estão em operação, gerando 76.136 .364 kW de potência, 110 usinas em construção e outras 243 com sua construção prevista. Das usinas em operação, 618 são termelétricas, representando uma potência de 11.174.321 kW, o que representa 14,68\% da potência total. As termelétricas estão também entre 52, das 110 usinas em construção (62,9\% da potência total prevista) e 82, das 243 usinas outorgadas, representando 59,23\% da potência prevista para as mesmas. Os números apresentados demonstram que o governo vem incentivando a maior participação das termelétricas na matriz energética do país.

A principal vantagem das usinas termelétricas é poderem ser construídas onde são mais necessárias, economizando assim o custo das linhas de transmissão. Essas usinas podem ser encontradas na Europa e em alguns estados do Brasil.

Conforme a ANEEL, entre as vantagens adicionais da geração termelétrica a gás natural estão o prazo relativamente curto de maturação do empreendimento e a flexibilidade para o atendimento de cargas de ponta.

De acordo com o último relatório do de Balanço Energético Nacional 2011, com base no ano de 2010, a proporção de energia renovável na matriz energética brasileira no ano de 2010 manteve-se alta, atingindo 45,4\%. Em 2010 o total de energia consumida no país atingiu 270,8 milhões de toneladas equivalentes de petróleo (Mtep), significando um aumento de 11,0\% em relação a 2009.

Houve crescimento de todas as fontes de energia no período 2009-2010, com destaque para o gás natural, cuja oferta interna aumentou 30,4\% em razão de aumentos expressivos na produção e na importação (respectivamente 8,5\% e 48,0\%), além da redução de 31,3\% nas queimas e perdas.

Forte crescimento do setor industrial. Entre os setores consumidores a indústria apresentou o maior aumento na demanda de energia no Brasil em 2010, com 13,0\% em relação a 2009. Este resultado evidencia a recuperação consistente do setor após a crise econômica mundial. Alguns segmentos se destacaram, apresentando significativa variação na produção física, tais como a siderurgia (23,8\%), ferro-liga (17,2 \%) e mineração (16,0\%). 
Em termos absolutos, a indústria nacional consumiu mais 9,9 Mtep, ou 49,9\% do acréscimo na demanda total de energia verificado no país no ano passado.

A produção de eletricidade registrou um acréscimo de 9,1\% em 2010. Observou-se um aumento de 48,2\% na geração através de fontes não renováveis, em relação ao ano anterior, com destaque para o gás natural $(+139,4 \%)$ e derivados de petróleo $(+17,0 \%)$.

Já a geração por meio de fontes renováveis apresentou aumento de 5,0\%, sendo que a energia eólica foi a que mais cresceu (+50,5\%), seguida pela biomassa (+18,1\%). Com a maior utilização das usinas termelétricas ano passado, o montante de eletricidade de origem renovável reduziu para 87,1\%, contra 90,5\% em 2009, conforme tabela 1 abaixo.

Tabela 1 - Oferta interna de energia elétrica

\begin{tabular}{lccc}
\multicolumn{1}{c}{ Fontes } & $\mathbf{2 0 1 0}$ & $\mathbf{2 0 0 9}$ & $\mathbf{\%}$ \\
Total & $\mathbf{5 4 8 , 8}$ & $\mathbf{5 0 2 , 9}$ & $\mathbf{9 , 1}$ \\
\hline Energia Não Renovável & $\mathbf{7 0 , 8}$ & $\mathbf{4 7 , 8}$ & $\mathbf{4 8 , 2}$ \\
\hline Gás Natural & 31,9 & 13,3 & 139,4 \\
Derivados de Petróleo & 17,1 & 14,7 & 17,0 \\
Nuclear & 14,5 & 13,0 & 12,1 \\
Carvão e Derivados ${ }^{1}$ & 7,2 & 6,8 & 5,2 \\
\hline Energia Renovável & $\mathbf{4 7 8 , 0}$ & $\mathbf{4 5 5 , 2}$ & $\mathbf{5 , 0}$ \\
\hline Hidráulica & 411,1 & 388,2 & 5,9 \\
Importação & 34,6 & 40,0 & $-13,3$ \\
Biomassa & 30,1 & 25,5 & 18,1 \\
Eólica & 2,18 & 1,45 & 50,5 \\
\hline
\end{tabular}

${ }^{1}$ Inclui gás de coqueria

${ }^{2}$ Inclui lenha, bagaço de cana, lixia, outras biomassas e recuperações

Fonte: ANEEL, 2011. 


\section{CARACTERIZAÇÃO GERAL DO SETOR ELÉTRICO}

\section{1}

\section{Histórico do Setor Elétrico Brasileiro}

A participação da eletricidade como fonte de energia era inexpressiva no período agrário, no final do século XIX. Com o início da industrialização, fatores como a concentração em centros urbanos e o surgimento de uma classe média impulsionaram seu uso.

A Centrais Elétricas Brasileiras S.A. (Eletrobrás) foi criada pela Lei ${ }^{\circ}$ 3.890-A, de 25 de abril de 1961, e instalada em 11 de junho de 1962, com o objetivo de promover estudos e projetos de construção e operação de usinas geradoras, linhas de transmissão e subestações, destinadas ao suprimento de energia elétrica do país.

Quando foi criada, a empresa agregou como subsidiárias a Companhia Hidroelétrica do São Francisco (Chesf), Furnas Centrais Elétricas, a Companhia Hidrelétrica do Vale do Paraíba (Chevap) e a Termelétrica de Charqueadas. Na época, a capacidade geradora instalada do país era de 5.800 MW.

A Eletrobrás assumiu desde o início as características de holding - núcleo de um conjunto de concessionárias com grande autonomia administrativa - e a gestão dos recursos do Fundo Federal de Eletrificação transformou-a rapidamente na principal agência financeira setorial.

Em 1964, foram ultimadas as negociações para a compra pelo governo brasileiro das concessionárias atuantes no Brasil do grupo Amforp. O negócio foi realizado em 14 de outubro e essas empresas passaram à condição de subsidiárias da Eletrobrás.

Em 1968, foi criada outra subsidiária de âmbito regional, a Centrais Elétricas do Sul do Brasil (Eletrosul) e em 1973, a última subsidiária regional da Eletrobrás foi instituída: a Centrais Elétricas do Norte do Brasil (Eletronorte). 
Neste último ano, a Eletrobrás estabeleceu, juntamente com a Administración Nacional de Electricidad, empresa estatal paraguaia, a Itaipu Binacional, visando à construção da hidrelétrica de Itaipu, no rio Paraná, na fronteira dos dois países.

Em seguida, a Lei n 5.899, de 5 de julho de 1973, atribuiu à Eletrobrás a competência para promover, através de suas empresas de âmbito regional, a construção e a operação de sistemas de transmissão em alta e extra-alta tensões, visando à integração interestadual dos sistemas e ao transporte de energia elétrica de Itaipu. Para tanto foram instituídos os Grupos Coordenadores para a Operação Interligada (GCOI).

Ao final da década de 1970, todas as concessionárias do setor de energia elétrica tinham capital nacional, com a compra pelo governo brasileiro das ações da Light à multinacional Brascan Limited, em janeiro de 1979.

Na década seguinte, o desempenho da Eletrobrás passou a se ressentir das dificuldades que vinham sendo enfrentadas pela economia brasileira. A recessão e a crise da dívida externa criaram um quadro de grave estrangulamento financeiro no setor. Essa situação agravou-se em 1988, com a extinção do Imposto Único sobre Energia Elétrica e a transferência para os estados da arrecadação tributária equivalente.

No início da década de 1990, o programa de obras de geração foi praticamente paralisado e foi iniciada uma reorganização institucional do setor, com a finalidade de reduzir a presença do Estado na economia. Em março de 1993, diminuiu-se o controle da União sobre os preços dos serviços de energia elétrica. Em 1995, foi sancionada pelo Executivo uma nova legislação de serviços públicos, na qual regras específicas para as concessões dos serviços de eletricidade foram fixadas; a figura do produtor independente de energia foi reconhecida, liberando os grandes consumidores do monopólio comercial das concessionárias; e o livre acesso aos sistemas de transmissão e distribuição foi assegurado.

Em maio de 1995, a Eletrobrás e suas quatro empresas de âmbito regional - Chesf, Furnas, Eletrosul e Eletronorte - foram incluídas no Programa Nacional 
de Desestatização. À época, o sistema Eletrobrás respondia por $48 \%$ da capacidade geradora instalada no país, totalizando 55.512 milhões de kW.

Para que se compreenda melhor o panorama do Setor Elétrico Brasileiro e a importância do Combate ao Desperdício de Energia Elétrica, é importante que fique claro que a predominância da geração hidráulica, com 95\% de geração é devido às dimensões continentais do país e da grande quantidade de bacias hidrográficas, considerada a maneira mais fácil e econômica.

Sendo o Brasil um país de dimensões continentais, onde a geração de energia elétrica depende da água (chuva), o sistema interligado permite que a energia elétrica seja produzida em usinas que tenham seus reservatórios com bom acumulo d'água, enquanto as que estão em período de seca poupem água e aumentem o nível de seus reservatórios. Assim, nenhum consumidor é prejudicado pela falta de chuvas em sua região;

Normalmente, usinas geradoras devem possuir estoque para eventuais excessos de demanda e de consumo de energia. Com o sistema interligado esta sobrecapacidade pode ser menor, reduzindo os investimentos em instalações sem comprometer a confiabilidade do fornecimento de energia elétrica.

A operação coordenada da geração e distribuição de energia elétrica proporciona uma disponibilidade de energia de 20 a $30 \%$ superior àquela que seria conseguida se as usinas operassem independentemente.

Devido a grande utilização da energia elétrica na sociedade, o seu fornecimento deve ser contínuo e ininterrupto. Ninguém está disposto a ficar sem a energia elétrica, seja qual for o período de tempo. Esse é mais um motivo para usar sem abusar.

Em países em desenvolvimento, como o Brasil, o crescimento do consumo de energia elétrica é uma constante (entre 3 e $5 \%$ a.a). Mesmo nos períodos em que se verificou uma estagnação econômica, o consumo não parou de crescer. Para atender a este consumo, novas usinas geradoras, sistemas de transmissão e distribuição devem ser construídos. 
A construção de Novas Usinas e Sistema de Transmissão está associada a grandes investimentos, longos prazos para conclusão das obras e significativos impactos ambientais.

As características físicas e geográficas do Brasil foram determinantes para a implantação de um parque gerador de energia elétrica de base predominantemente hidráulica. Como cerca de $25 \%$ de todo o potencial hidrelétrico conhecido correspondem a usinas em operação e em construção, estima-se que pelo menos nas duas próximas décadas, as fontes hidráulicas continuarão a desempenhar importante papel no atendimento à crescente demanda de energia elétrica.

A exploração desse potencial era, tradicionalmente, efetuada por empresas de economia mista (aquelas em que o acionista majoritário é a União), os governos estaduais ou municipais, que respondem por mais de $99 \%$ da produção nacional de energia elétrica para uso público. Hoje, cada vez mais, essa exploração tem a participação da iniciativa privada.

A edição da lei 10.848/2004 (BRASIL, 2011), definiu o novo modelo do setor elétrico brasileiro, alterou profundamente as regras de comercialização de energia elétrica no País. A energia só pode ser contratada sob duas formas: de acordo com as regras do Ambiente de Contratação Regulada (ACR) ou de acordo com o as regras do Ambiente de Contratação Livre (ACL).

Porém, independentemente do caráter público ou privado dos agentes encarregados do suprimento de energia elétrica, é muitíssimo importante que a operação e a expansão do sistema elétrico brasileiro, continuem a ser realizadas de forma coordenada, com alto grau de interligação entre seus componentes. Esta interligação permite obter dos sistemas uma produção energética superior àquela que seria proporcionada pela soma das produções das usinas em operação isolada, como já mencionado anteriormente.

Segundo a ELETROBRAS, na apresentação do selo PROCEL, em 2030 o Brasil deverá estar assim em energia elétrica. Capacidade nominal instalada de 216,6 milhões kW (156,0 milhões kW de hidroelétricas, 39,8 milhões de kW térmicos, destes, 21,0 milhões à gás natural, 6 milhões a carvão, 7,35 milhões a 
combustível nuclear, e 5,5 milhões outros, e, ainda, 30,8 milhões de energia alternativa (PCHs, biomassa e eólica).

Pela tabela 2, abaixo apresenta a participação no mercado brasileiro, das inúmeras formas de geração de energia elétrica atualmente empregada, no contexto energético.

Tabela 2 - Parque Gerador de energia em Dezembro de 2010

\begin{tabular}{|c|c|c|c|}
\hline Tipo & Quantidade & Potência (MW) & \% Total \\
\hline \multicolumn{4}{|c|}{ Convencionais } \\
\hline Eólicas - EOL & 36 & 602,28 & 0,57 \\
\hline $\mathrm{PCHs}^{1}$ e $\mathrm{CGH}^{2}$ & 663 & $3.126,13$ & 2,94 \\
\hline Hidroelétricas - UHE* & 165 & $75.484,24$ & 71,01 \\
\hline Termelétricas - UTE & 1313 & $25.081,35$ & 23,59 \\
\hline \multicolumn{4}{|c|}{ Não Convencionais } \\
\hline Usina Termonucler - UTN & 2 & 2.007 & 1,89 \\
\hline Totais & 2179 & $106.301,00$ & 100,0 \\
\hline
\end{tabular}

*Considerando o lado brasileiro de Itaipu binacional (7000MW)

Fonte. Fonte ANEEL, 2010

Pelos dados apresentados, nota-se a evidente predominância hidrelétrica e a participação complementar de unidades termelétricas convencionais. Destacando-se, também, que as demais fontes, ainda apresentam participações apenas reduzidas.

\section{2}

\section{Especificidades das Hidroelétricas no Brasil}

O uso da energia elétrica proveniente da geração a partir do uso de recursos hídricos foi uma das primeiras formas de substituição do trabalho animal

\footnotetext{
${ }^{1} \mathrm{PCH}$ - Pequenas Centrais Hidrelétricas

${ }^{2} \mathrm{CGH}$ - Central geradora hidrelétrica
} 
pelo trabalho mecânico, especialmente para bombeamento de água e moagem de grãos.

Nesse sentido, entre as características energéticas mais relevantes, destacam-se as seguintes características, a saber: a) disponibilidade de recursos; b) facilidade de aproveitamento; e c) seu caráter renovável.

Em contraposição às demais fontes renováveis, o processo hídrico representa uma parcela expressiva da matriz energética mundial e possui tecnologias devidamente consolidadas há séculos. Atualmente, a produção de energia elétrica pelos processos hídricos é a principal fonte geradora de energia empregada por mais e 30 países e vem a representar cerca de $20 \%$ de toda a eletricidade gerada no mundo atualmente (SAUER, 2003).

O Brasil, atualmente conta com o maior parque hidrelétrico de todo o mundo, vindo a representar aproximadamente $79 \%$ de toda a energia elétrica produzida no país. Destaca-se que a geração de energia elétrica no Brasil em centrais de serviço público e autoprodutores atingiu 466,2 TWh em 2009, resultado 0,7\% superior ao de 2008 (BRASIL, 2011 )

No Brasil, água e energia apresentam uma ampla e histórica interdependência, de forma a vir a contribuir para a geração da energia hidráulica e desta forma, contribuir com o desenvolvimento econômico do país de forma expressiva, sejam elas no atendimento dos inúmeros processos e demandas da economia, tais como: a) As atividades industriais; b) Agrícolas; c) Comerciais e de serviços; ou d) Da própria sociedade (SEVÁ e BERMANN, 2006).

Desta forma, o que se pode observar, é uma otimização do conforto das habitações e a qualidade de vida da sociedade, por conseguinte, vem desempenhando um papel importante na integração e desenvolvimento de regiões distantes dos grandes centros urbanos e industriais, conforme citado anteriormente.

A razão de se ter priorizado a implantação de usinas hidrelétricas deve-se, inicialmente, ao grande potencial hidrelétrico existente no país e à competitividade econômica que tais fontes apresentam. Nesse sentido, o parque 
termelétrico nacional apresenta, no caso do Sistema Interligado Brasileiro, um caráter complementar, objetivando aprimorar a confiabilidade do sistema que no caso de ocorrência de eventos hidrológicos críticos, conforme se verificou ao longo da ultima década. Assim, considera-se que esta atividade norteia-se fundamentalmente ao atendimento localizado, caso ocorram restrições nos elos de interligação, e ao atendimento a sistemas isolados, nos quais, atualmente, apresentam papel de grande relevância.

Conforme citado anteriormente, a geração de energia elétrica se dá por vários meios e o principal deles no Brasil é por meio hidrelétrico, esta geração transforma energia mecânica em energia elétrica conforme se observa pelas figuras 1 e 2.

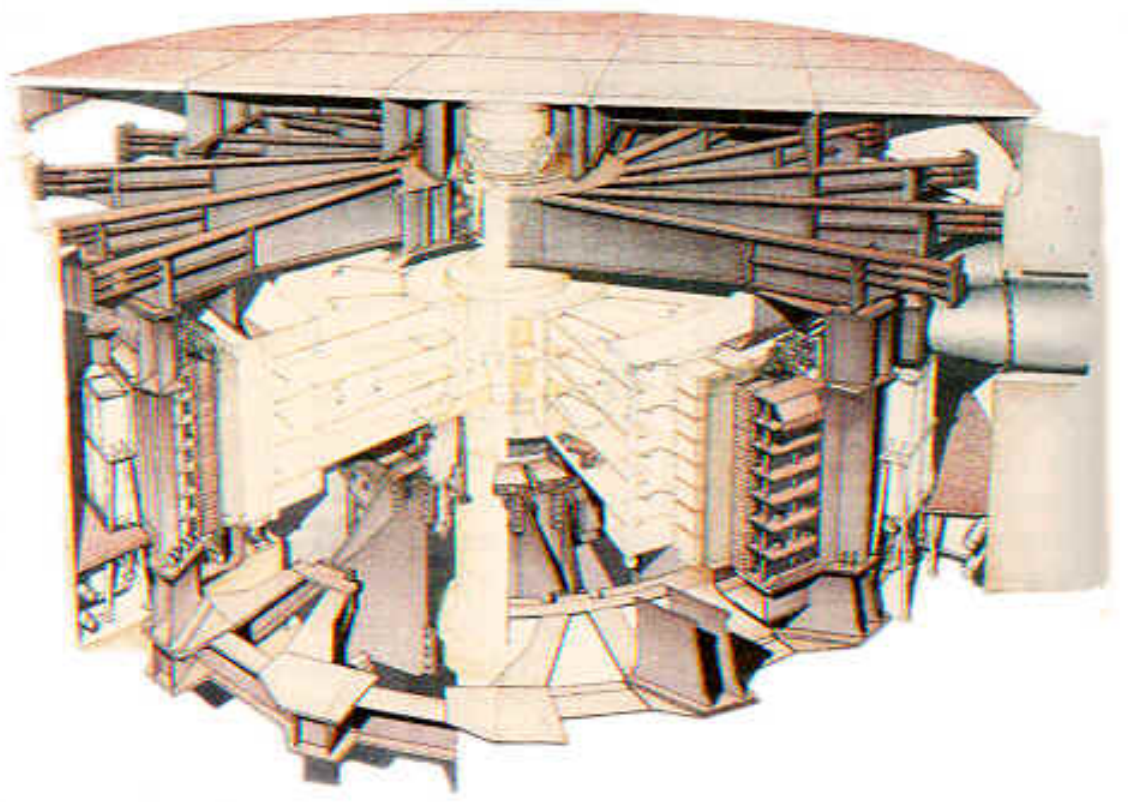

Figura 1 - Exemplo de uma turbina em uma usina hidroelétrica 


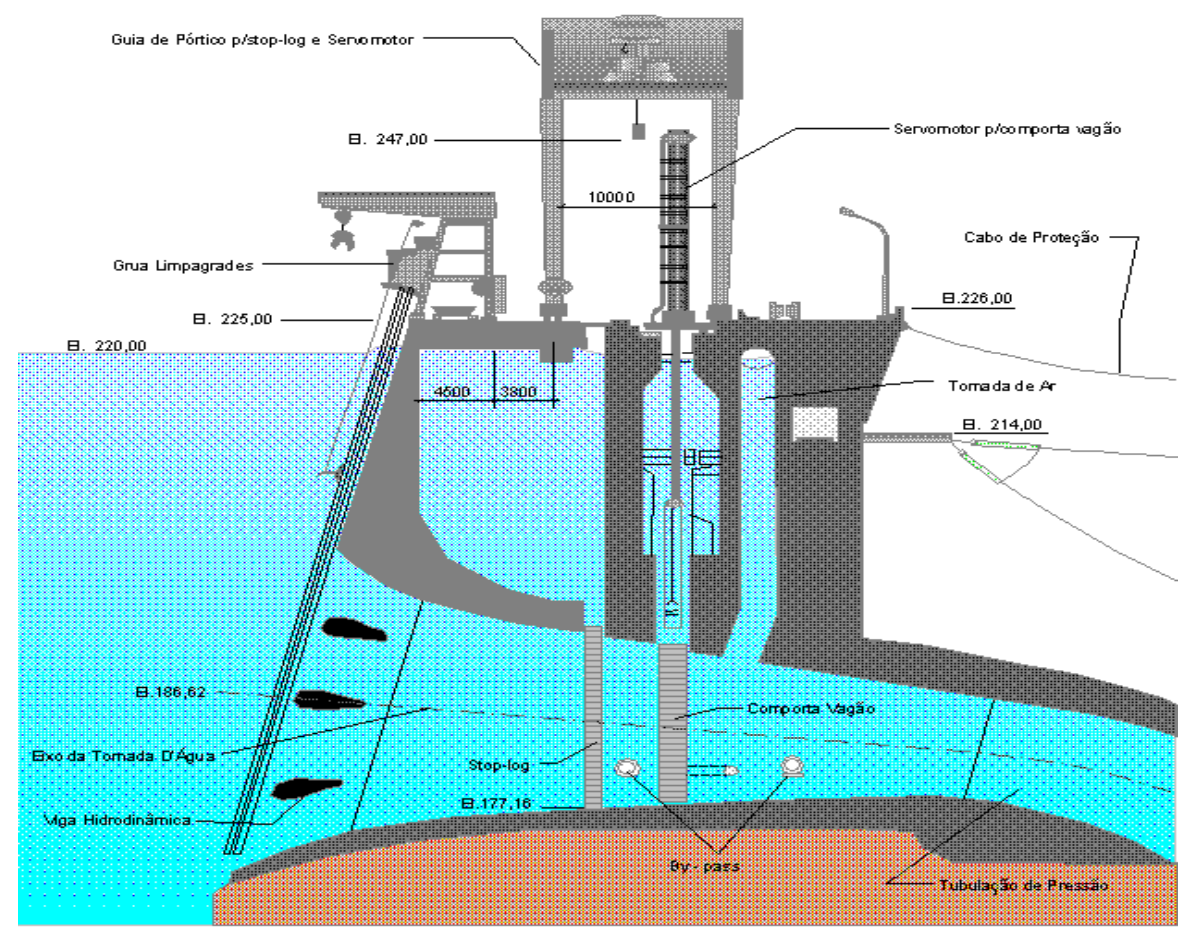

Figura 2 - Modelo esquemático de Entrada de água em uma Comporta de uma Usina Hidroelétrica

No contexto do processo evolutivo, observa-se que a partir da década de 1990, nota-se um decréscimo na participação relativa da energia de origem hidrelétrica, principalmente em função chegada ao Brasil do Gás Natural bem como incentivos por parte do Governo Federal da Cogeração de energia e o incentivo a busca de produção de energias alternativas. Ressalta-se ainda, a manutenção de um programa nuclear mínimo e a implantação do gasoduto Brasil - Bolívia (SEVÁ e BERMANN, 2006).

A geração de energia hidroelétrica, entretanto, continua sendo a fonte amplamente dominante. O potencial hidrelétrico brasileiro representa o somatório de todas as demais potências energéticas analisadas. A avaliação desse potencial considera as etapas de estudo e implantação dos aproveitamentos conforme as definições tradicionalmente adotadas no setor elétrico ${ }^{3}$. Os aproveitamentos nos

\footnotetext{
${ }^{3}$ Remanescente - resultado de estimativa realizada em escritório, a partir de dados existentes, sem qualquer levantamento complementar, considerado um trecho do curso d'água, via de regra situado na cabeceira, sem determinar os locais de implantação dos aproveitamentos; Individualizado - resultado de estimativo realizado em escritório para um determinado local, a
} 
estágios de levantamento, viabilidade ou projeto básico só são considerados no apuramento do potencial se os seus respectivos estudos obtiverem sua aprovação no órgão regulador.

Os dados que mensuram o conhecimento do potencial hidrelétrico brasileiro são objeto de atualizações constantes, em contraposição ao aprofundamento das analises do potencial já pesquisado e de novos levantamentos efetuados.

\section{3}

\section{Impactos sócio-ambientais gerados pelas hidrelétricas}

O potencial hidrelétrico brasileiro representa uma vantagem indiscutível, em relação aos modelos de produção de energia de outros países, que, por conseguinte, empregam na produção de energia elétrica, essencialmente os combustíveis fósseis e/ou de centrais nucleares. Além de referir-se a uma fonte abundante, limpa e renovável (não inesgotável), a alternativa hidrelétrica constitui atualmente uma área de pleno domínio pela tecnologia nacional empregada.

Essa característica de nossa fonte energética principal constitui-se, entretanto, na origem de um conjunto de fundamentais condicionantes para o setor elétrico brasileiro. Além da própria dialética interna do sistema, que envolve políticas fundamentais e ações direcionadas à regulação e controle do uso dos

partir de dados existentes ou levantamentos expedidos, sem um levantamento detalhado; Inventário - resultado do estudo de uma bacia hidrográfica, realizado para a determinação do seu potencial hidrelétrico através da escolha da melhor alternativa de divisão de queda, caracterizada por um conjunto de aproveitamentos na bacia, compatíveis entre si, de forma a se obter uma avaliação da energia disponível, dos impactos ambientais e dos custos de implantação dos empreendimentos; Viabilidade - resultado de uma concepção global do aproveitamento, considerando sua otimização técnica - econômica e compreendendo o dimensionamento das estruturas principais e das obras de infra-estrutura local a definição da respectiva área de influência, os possíveis usos múltiplos da água e os efeitos da obra sobre o meio ambiente; Projeto básico - projeto detalhado, inclusive no que diz respeito ao orçamento da obra, de forma a permitir a elaboração dos documentos de licitação das obras civis e do fornecimento dos equipamentos eletromecânicos; Construção - aproveitamento que teve suas obras iniciadas, sem possuir, no entanto, nenhuma unidade geradora em operação; Operação - aproveitamento que dispõe de, pelo menos, uma unidade geradora em operação. (BRASIL, 2011c). 
recursos hídricos, existe a necessidade de articulação e adequação com outras instituições envolvidas no processo de aprovação dos aproveitamentos.

Essas condicionantes envolvem alusões que podem ser definidas como de ordem estratégica. Ressalta-se que o crescimento da demanda se impõe ao planejamento da expansão da oferta de energia, estabelecendo previsões bastante antecipadas e minuciosas, tendo em vista o tempo demandado para os estudos envolvidos, tais como: inventário, viabilidade, projeto básico e executivo e, principalmente, nos prazos de construção das usinas hidrelétricas, que são bastante longos.

Nas implicações de ordem técnica, devem ser considerados os fatores estruturais, incluindo às vantagens e desvantagens, bem como as necessidades de interligações nos sistemas de transmissão de energia, com a finalidade de se aproveitar da diversidade regional dos regimes hidrológicos e da geografia local; e ao porte dos empreendimentos, em relação aos ganhos do fator de escala dos aproveitamentos e da magnitude dos principais rios a serem utilizados. Ainda em referencia técnico, é preciso ressaltar, que os fatores operacionais, que podem tornar as usinas fortemente dependentes do regime de vazões do rio e da maior ou menor regulação promovida pelo conjunto de barramentos situados numa mesma bacia, além das procedentes regras de deplecionamento dos reservatórios, tendo como finalidade também a questão dos usos múltiplos da água, geralmente considerada nesses empreendimentos.

Por fim, em ressaltam-se as implicações derivadas de ordem ambiental, associadas aos impactos das usinas hidrelétricas, com especial evidência para a área inundada pelos reservatórios e suas consequências sobre o meio físico-biótico e sobre as populações atingidas. As preocupações com essas questões são agravadas pelo fato da maior parte do potencial hidrelétrico atual remanescente estar localizado em áreas de condições socioambientais delicadas, por suas interferências sobre territórios indígenas, sobretudo na Amazônia, sobre áreas de preservação, sobre recursos florestais, ocupações antrópicas, etc. São também fundamentais os estudos e equacionamentos relacionados aos usos diversos e, eventualmente, concorrenciais desses recursos hídricos, em suas feições 
socioeconômicas, ambientais e estratégicas, relativas à pesca, abastecimento urbano, saneamento básico, irrigação, transporte, lazer, etc.

Segundo pesquisas, há duas formas de produção de gases quentes numa usina hidrelétrica: por difusão ou por bolhas. O primeiro caso ocorre na superfície do reservatório. Por ser um meio aeróbico, com maior presença de oxigênio, as bactérias decompõem a matéria orgânica e emitem gás carbônico, que se difunde pela água.

Já o metano é obtido por decomposição de matéria orgânica no fundo dos lagos das usinas, onde a presença de oxigênio é nula ou muito pequena. "Como não se dilui na água, esse metano chega à superfície por meio de bolhas”.

Em reservatórios com grande profundidade, acima de 40 metros, o metano não consegue subir à superfície. “A pressão da água impede que a bolha de metano atinja a superfície”

A relação entre a potência energética e a geometria do reservatório é fundamental para a maior ou menor produção de gases quentes. "Lagos profundos em áreas pequenas, e com grande potência energética, emitem pouco gases deste tipo. Este é o caso de Itaipu”.

Agora, lagos rasos, em áreas extensas, e com pouca densidade de potência, como é o caso da hidrelétrica de Balbina, no Amazonas, são grande poluidores (APOENA,2011).

\section{4}

\section{Especificidades das Usinas Termelétricas a Gás Natural}

O gás natural é, em princípio, isento de enxofre e de cinzas, o que torna dispensáveis as custosas instalações de desulfurização e eliminação de cinzas que são exigidas nas térmicas a carvão e a óleo. O problema da chuva ácida é mínimo em uma térmica a gás natural, e a contribuição para o aquecimento global, por KW gerado, é muito menor que nas correspondentes a carvão e óleo, por força da melhor eficiência térmica. Como o gás natural é rico em hidrogênio quando 
comparado aos demais combustíveis fósseis, a proporção de gás carbônico gerado por sua queima é significativamente mais baixa.

O problema ambiental mais acentuado nas instalações a gás natural é o de emissão de óxidos de nitrogênio, conhecidos por "NOx". Uma turbina a gás tem níveis maiores de NOx do que caldeiras a óleo ou carvão porque a relação entre o ar e o combustível é muito maior na queima do gás. Os últimos desenvolvimentos técnicos prevêm a utilização de queimadores com injeção de água ou vapor na zona de combustão das turbinas, o que além de reduzir o NOx, ainda eleva a capacidade produtiva de máquina por aumento do fluxo de massa através da turbina.

A idéia popular de que turbinas a gás produzem alto nível de ruído impressão que vem das turbinas de avião - não é verdadeira.

Atualmente existem três categorias de tecnologias de geração a gás natural empregadas no Brasil, ou seja: ciclo aberto, que utiliza turbinas a gás em ciclo de Brayton; ciclo combinado, que é acoplado ao ciclo aberto e se emprega uma turbina a vapor para geração adicional de eletricidade; e usinas de coogeração, onde existe uma produção combinada da energia eletromecânica e calor, possibilitando a utilização das duas categorias apresentadas anteriormente (GUERREIRO, et al., 2006).

Observa-se que o rendimento térmico das turbinas a gás, apesar dos ganhos alcançados, operando em ciclo simples, tem seu desempenho prejudicado pela perda de energia nos gases de exaustão e, em consequência desse fato, o custo da energia gerada por essas usinas é elevado, visto que o gás natural é muitas vezes importado e atrelado ao dólar, ademais, sua eficiência ainda é baixa em comparação as demais tecnologias tais como, por exemplo, o ciclo combinado, já mencionado.

Existem vários tipos de usinas termoelétricas, sendo que os processos de produção de energia são praticamente iguais porém com combustíveis diferentes. Alguns exemplos são: Usina a óleo combustível; Usina a gás natural Usina a carvão; Usina nuclear. 
Descreveremos os tipos de configurações e benefícios de cada tipo de configuração de termelétricas a gás natural.

A termelétrica a gás natural de ciclo combinado ("Combined Cycle Power Stations", CCPS's"), um tipo de usina térmica que vem sendo adotado em todo o mundo, desde a década de oitenta, considerada a solução na grande maioria dos casos - No Brasil estão sendo construídas cerca de 35 usinas, totalizando mais de 12.000 megawatts (MW).

Uma usina a ciclo combinado usa turbinas a gás e a vapor associadas em uma única planta, ambas gerando energia elétrica a partir da queima do mesmo combustível. Para isto, o calor existente nos gases de exaustão das turbinas a gás é recuperado, produzindo o vapor necessário ao acionamento da turbina a vapor. Vejamos abaixo as principais características das CCPS's.

O principal elemento das termelétricas de ciclo combinado são as turbinas a gás, uma tecnologia em grande parte proveniente dos jatos desenvolvidos para as aeronaves militares e civis, também chamadas de aeroderivativas, entretanto nas termelétricas o combustível utilizado cada vez mais é o gás natural, embora seja quase sempre dada a possibilidade de operar com um segundo combustível, como o diesel, para evitar interrupções no caso de problemas no suprimento do gás, este tipo de configuração vem sendo utilizado no estado do Amazonas em unidades da Manaus Energia , subsidiária da Eletronorte.

Podemos distinguir três componentes principais em uma turbina à gás: o compressor, o sistema de combustão e a turbina propriamente dita, esta última sendo a fonte de acionamento tanto do compressor como de um gerador de energia elétrica. $\mathrm{O}$ ar atmosférico captado pelo compressor é comprimido no sistema de combustão à pressão de cerca de 13 bar, e temperatura da ordem de $375^{\circ} \mathrm{C}$, a qual se eleva a $1250^{\circ} \mathrm{C}$ com a queima do gás. A energia gerada na expansão que se segue à queima do gás aciona a turbina, reduzindo-se a pressão à atmosférica e a temperatura a cerca de $550^{\circ} \mathrm{C}$ nos gases de exaustão da turbina.

Em algumas situações, se uma turbina estiver operando isoladamente, ou em ciclo aberto (“open cycle mode”), como nas aeronaves, sua eficiência térmica é baixa, da ordem de $36 \%$, ou seja, mais de $60 \%$ do calor gerado pela queima do 
combustível é perdido nos gases de exaustão. É verdade que a eficiência térmica pode ser melhorada com temperaturas e pressões de entrada mais elevadas, mas isto exigiria materiais mais caros ao longo do caminho do gás, com limitações técnicas e econômicas que podem ser relativizadas no caso de unidades aeronáuticas (especialmente militares), mas são relevantes nas turbinas industriais. Nestas, é fundamental compatibilizar temperaturas e pressões com custos iniciais e de manutenção, esta sempre trabalhosa e demorada.

Assim, não é de se esperar que, mesmo com os desenvolvimentos técnicos já antevistos, as turbinas industriais em ciclo aberto venham a ter eficiência térmica acima de $40 \%$, o que torna este sistema desinteressante para a geração de energia elétrica. A Fig. abaixo mostra este esquema, com o fluxo numérico de energia da unidade.

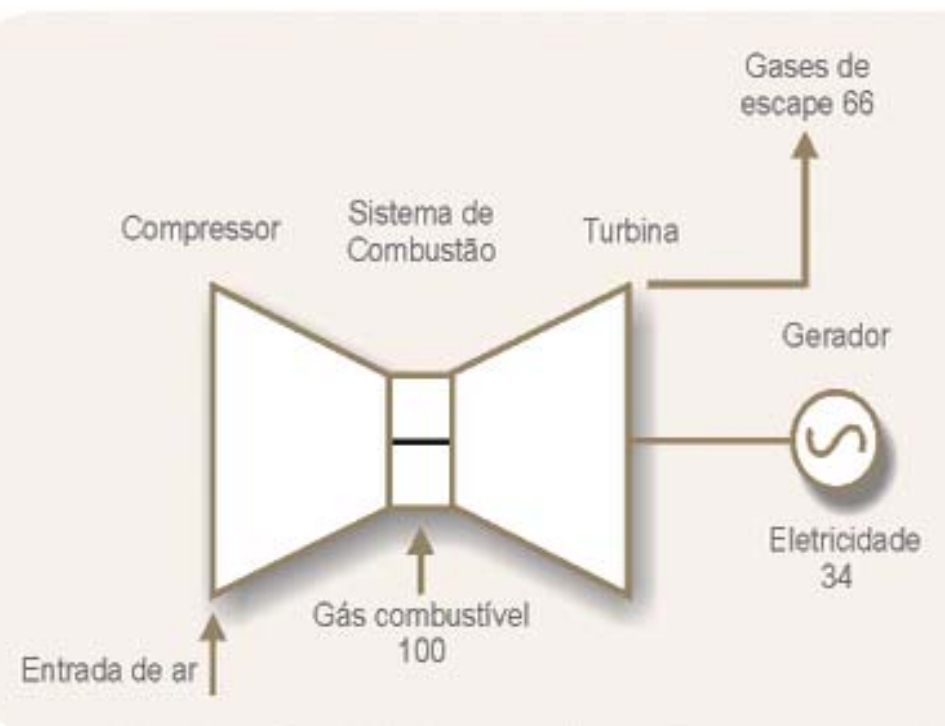

Figura 3 - Turbina a gás em ciclo aberto Fonte: http://www.gasnet.com.br/novo_termeletricas/ciclo.asp

Caldeira de recuperação de calor - HRSG, como dissemos acima, as CCPS's têm como um dos seus principais elementos um gerador de vapor capaz de recuperar parte do calor dos gases de exaustão das turbinas a gás (Heat Recovery Steam Generator - HRSG). Com isto, a eficiência térmica eleva-se substancialmente, como se vê na Fig. à seguir, pois o vapor assim produzido aciona uma turbina, sem necessidade de queima de combustível adicional. 


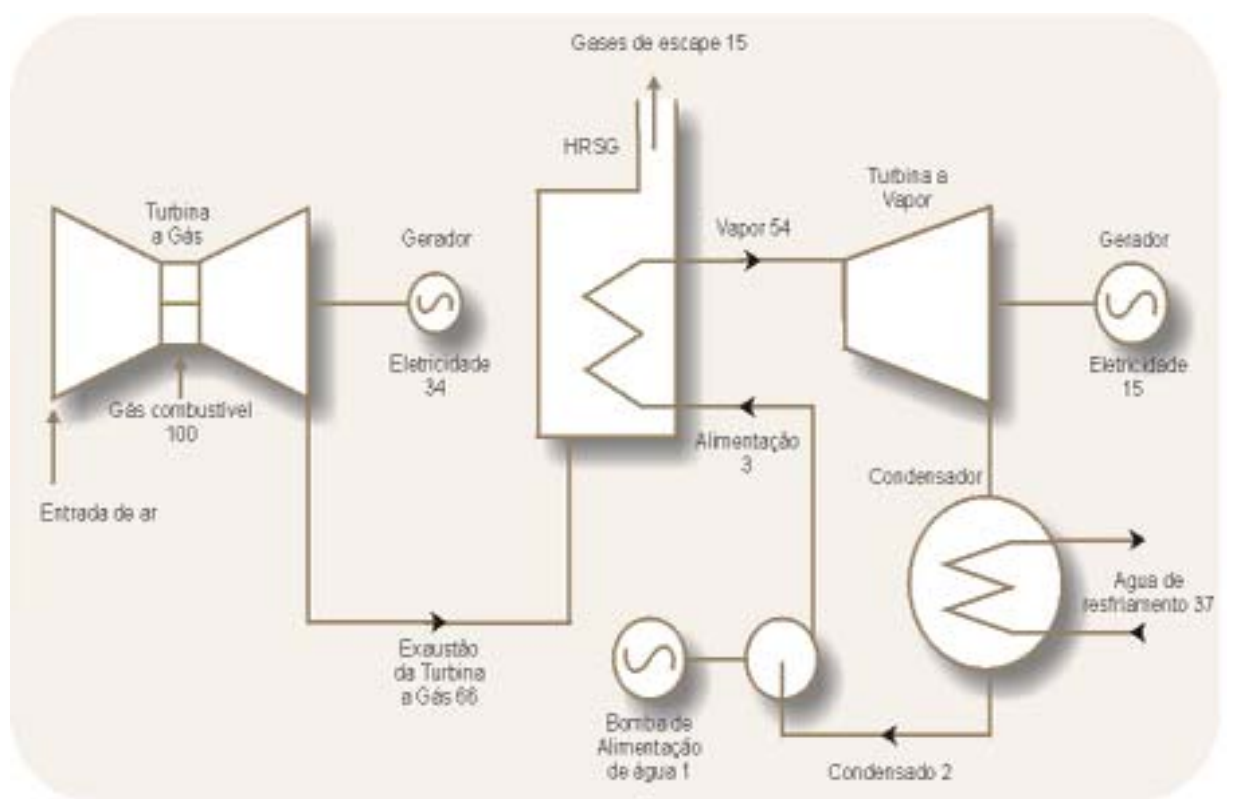

Figura 4 - Turbina a gás em ciclo combinado Fonte: http://www.gasnet.com.br/novo_termeletricas/ciclo.asp

A temperatura máxima que, nestas condições, pode ser obtida no vapor depende da temperatura dos gases de exaustão, que, como vimos, é da ordem de $550^{\circ} \mathrm{C}$. Um bom número é vapor a $520^{\circ} \mathrm{C}$, e 105 bar de pressão. A quantidade de vapor produzida é suficiente para acionar uma turbina capaz de gerar a metade da energia elétrica da turbina a gás correspondente. Em consequência, um dos arranjos clássicos de uma CCPS são duas turbinas a gás e uma a vapor, todas da mesma capacidade - p.ex., 150 MW cada uma.

Diferentemente dos gases de exaustão de uma turbina a óleo ou de um motor diesel, os gases provenientes de uma turbina a gás ainda contém oxigênio, o que permite a queima suplementar de combustível, se for desejado vapor a temperaturas mais elevadas ou em maior quantidade. Nas instalações comerciais, entretanto, este esquema é pouco usado, pois a eficiência térmica global é menor.

Turbina a Vapor, considerado o terceiro elemento básico nas CCPS's é a turbina a vapor, cuja função é gerar energia elétrica adicional a partir do vapor produzido no HRSG. Seu funcionamento não difere das turbinas usadas em termelétricas convencionais a vapor, com queima de carvão ou óleo. O vapor saído da turbina é condensado e volta a ser usado como água de alimentação do HRSG. 
Caso a instalação esteja à beira-mar ou próxima de um rio, a preferência é pelo condensador a água, com passagem única. Se isto não for possível, podem-se ter torres de resfriamento (as enormes torres de concreto com perfil parabólico são típicas de termelétricas) ou mesmo, caso não haja água disponível, radiadores resfriados a ar. Neste último caso, os investimentos tendem a crescer e a eficiência térmica da planta fica reduzida.

A escolha das turbinas a gás determina a capacidade de produção de uma termelétrica de ciclo combinado. Não se pode, porém, arbitrar livremente a potência de uma turbina, pois os poucos fabricantes mundiais têm suas máquinas padronizadas. Encontram-se turbinas a gás desde $1 \mathrm{MW}$ a $330 \mathrm{MW}$, mas a grande maioria das termelétricas a gás natural usa unidades entre 120 e 330 MW. As capacidades são referidas às condições "ISO", ou seja, temperatura ambiente de $15^{\circ} \mathrm{C}$ e nível do mar, e serão reduzidas para temperaturas mais elevadas e altitudes maiores.

Como vimos, o vapor gerado em uma caldeira de recuperação de calor permite acionar uma turbina de potência igual à metade da turbina a gás correspondente. Isto significa turbinas a vapor de 60 a $165 \mathrm{MW}$, e o tamanho prático de uma instalação com uma turbina a gás e sua correspondente a vapor será de $180 \mathrm{MW}$ ou maior.

Em instalações de uma única turbina a gás, a que nos referimos no parágrafo anterior, dois arranjos são possíveis: o mais tradicional prevê geradores elétricos separados, acoplados à turbina a gás e à turbina a vapor, mas é possível acoplar as duas para acionarem um único gerador. A Figura 5 à seguir mostra um esquema deste tipo. A opção por uma única turbina a gás limita a capacidade total da usina a cerca de $500 \mathrm{MW}$, e traz problemas de parada total se uma das máquinas apresentar problemas. 


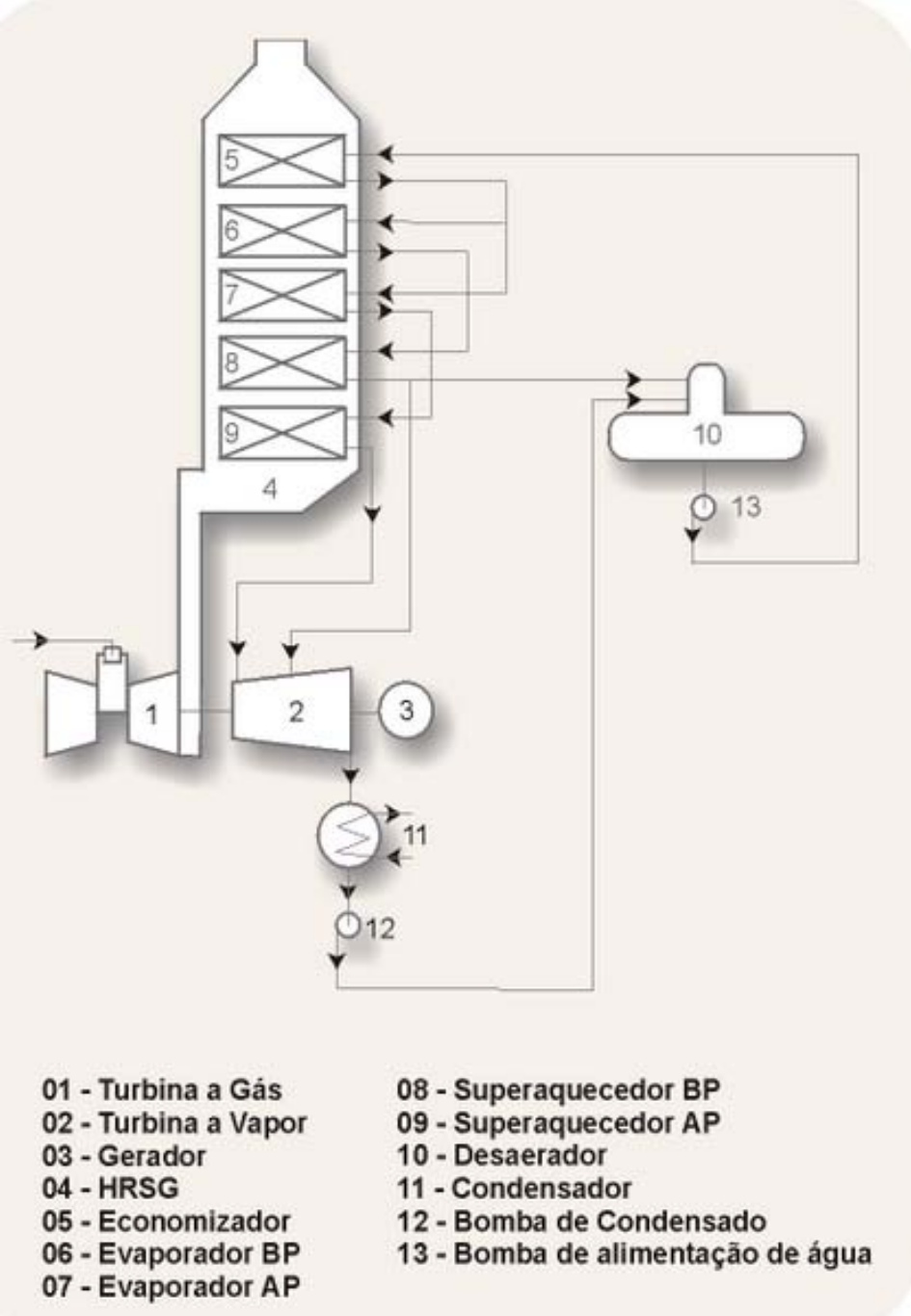

Figura 5 - Termelétrica a Ciclo Combinado (CCPS) Tipo 1 + 1- em eixo único Fonte: http://www.gasnet.com.br/novo_termeletricas/ciclo.asp

A maioria das térmicas a gás natural em funcionamento ou construção adota a configuração de mais de uma turbina a gás, pois desta forma não há limite à capacidade da usina, e os riscos de paralisação são reduzidos. Como já vimos, um modelo clássico é o chamado $2+1$, com duas turbinas a gás iguais, cada uma com seu HRSG, e uma a vapor de mesma capacidade. Desta forma, é possível usar três geradores elétricos de mesmo porte para as três turbinas, com transformadores e demais equipamentos elétricos também padronizados. Um arranjo deste tipo pode ser visto na Figura 6, à seguir: 


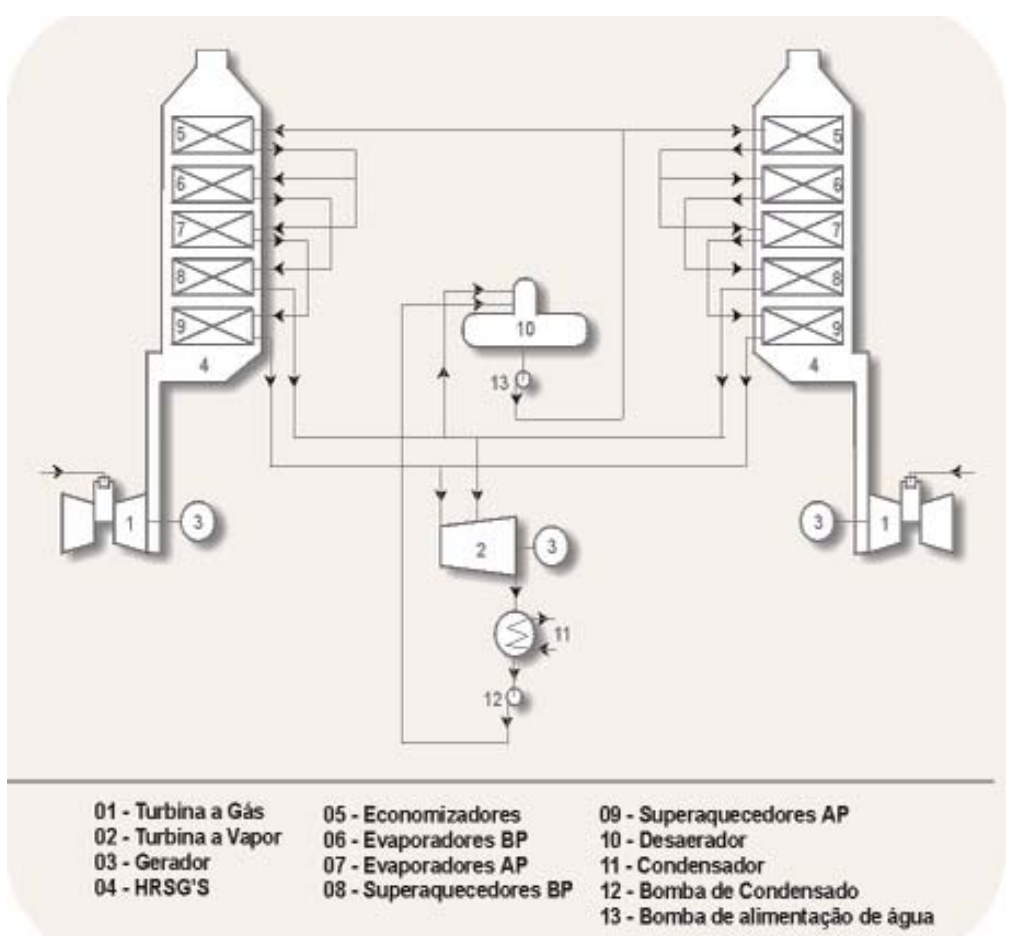

Figura 6 - Fluxograma típico de uma Termoelétrica de Ciclo Combinado (CCPS) - Tipo $2+1$

Fonte: http://www.gasnet.com.br/novo_termeletricas/ciclo.asp

Neste tipo de configuração é possível parar uma turbina a gás e seu HRSG reduzindo a capacidade total à metade. Caso a turbina a vapor pare, pode-se operar com o chamado ciclo aberto, com grande redução na eficiência térmica. Com base na potência comercialmente disponível das turbinas a gás, conclui-se que uma usina tipo $2+1$ terá capacidade total entre 360 e $990 \mathrm{MW}$, embora este limite superior seja na prática de cerca de 800 MW. Uma atenção especial em instalações deste tipo (mais de uma turbina) deve ser dada à divisão de carga entre as máquinas a gás, de forma a equalizar temperaturas e pressões no vapor produzido por seus HRSG's.

A combinação de turbinas a gás e a vapor não está limitada ao arranjo $2+$ 1. Há exemplos de até 5 turbinas a gás associadas a uma a vapor, e arranjos de $3+$ 1 e $4+1$ estão em uso comercial em diferentes localizações. O emprego de grandes turbinas a vapor, entretanto, traz dificuldades técnicas a medida que aumenta o número das caldeiras de recuperação de calor que, em paralelo, a alimentam. 
É importante quando falamos em energia sempre lembrar de duas palavras fundamentais, eficiência e disponibilidade .

A eficiência térmica das CCPS's é melhor que as maiores e mais modernas usinas a carvão ou a óleo. Como exemplos, temos a usina de Drax, na Inglaterra, uma termelétrica a carvão de $4.000 \mathrm{MW}$, que chega a 40\% de eficiência, ou os melhores motores diesel, que podem atingir $44 \%$.

A estas instalações comparam-se as CCPS's - termelétricas a gás natural de ciclo combinado, capazes de atingir 56\% de eficiência térmica. Mesmo usinas mais antigas ficam acima de 47\%, valores que, com a tecnologia hoje disponível, não são encontrados em nenhuma outra térmica comercialmente em uso.

Diz-se que uma planta perde disponibilidade quando cessa de gerar energia elétrica, seja por paradas programadas, paradas imprevistas ou restrições à produção de qualquer natureza. A disponibilidade é avaliada em bases anuais e termos percentuais, comparando-se a totalidade das horas do ano com as do efetivo funcionamento.

As paradas programadas de uma CCPS são em geral determinadas pelas turbinas a gás, que normalmente são previstas para trabalhar até 8000 horas sem interrupção. Na prática, a perda de disponibilidade situa-se entre 2 e 12\% ao ano, fixando-se em $5 \%$ em um horizonte de 5 anos. Os demais componentes de uma CCPS - HRSG e turbina a vapor - terão sua manutenção contida nestes prazos.

Dados estatísticos mostram que as demais perdas de disponibilidade situam-se entre 3 e $6 \%$, o que significa que algo próximo a $90 \%$ pode ser antecipado como disponibilidade média de uma CCPS.

Em CCPS's bem projetadas, a poluição sonora não excede a de usinas equivalentes operando a vapor, e situa-se facilmente nas exigências legais.

Uma vantagem deste tipo de termelétrica é o de ocupar espaços reduzidos em relação aos demais. Uma instalação típica, 2 + 1, de 360 MW pode ser feita em um terreno de 200 x 400 metros, como pode ser visto na Figura 7. 
Também na altura das chaminés as CCPS's trazem vantagens sobre térmicas a carvão ou óleo. Como o gás é basicamente isento de enxofre e cinzas, a chaminé de concreto com 250 m de altura, típica de grandes usinas, pode ser substituída por duas peças de 75 m , em aço. A não existência de grandes áreas de estocagem de carvão ou parque de tanques de óleo é ainda um ponto a favor das usinas a gás natural, embora nelas existam, como se pode observar na Figura 7, à seguir, reservatórios para combustíveis de reserva.
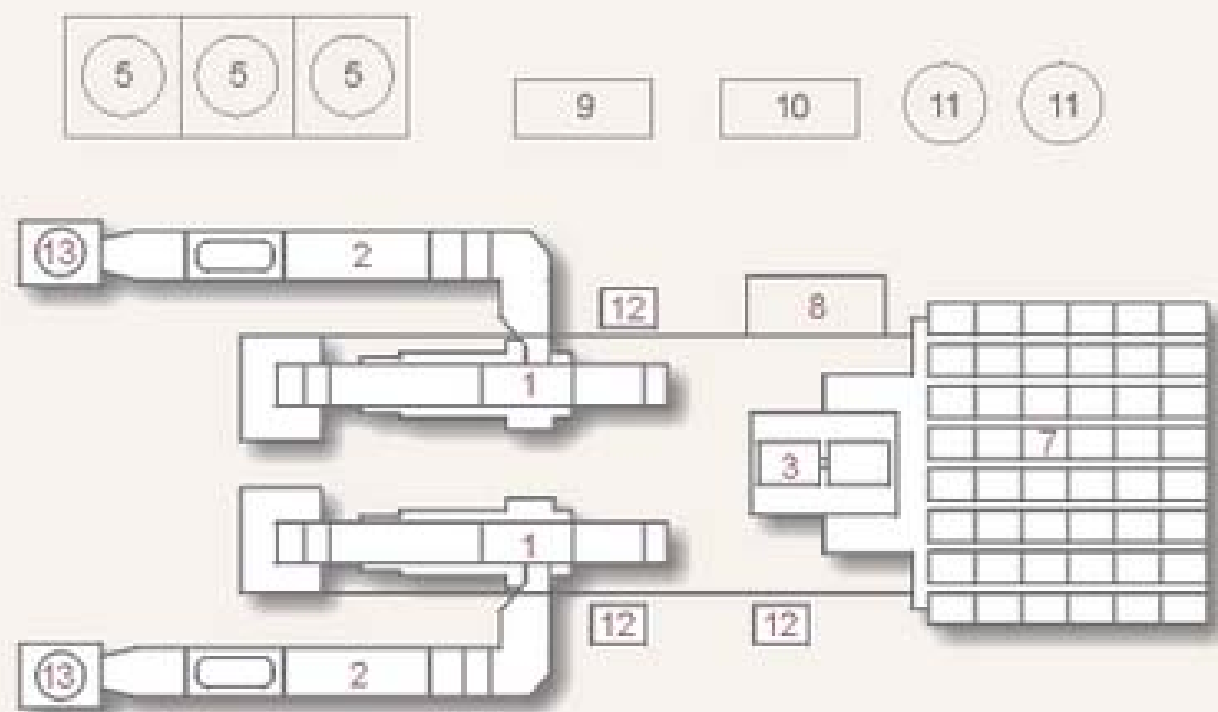

4

\section{6}

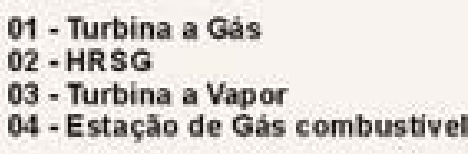

02 - HRSG

04 - Estaçăo de Gás combustivel

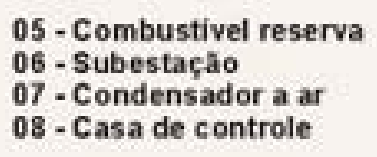

06 - Subestaçăo

08 - Casa de controle
09 - Oficinas / Almoxarifado

10 - Tratamento de água

11- Reservatórios de água

12- Transformadores

13 - Chaminé

Figura 7 - Arranjo típico de uma Termoelétrica a Ciclo combinado (CCPS) Fonte: http://www.gasnet.com.br/novo_termeletricas/ciclo.asp

Atualmente, com o número de CCPS's aumentando em todo o mundo, os prazos de entrega de turbinas a gás têm se alongado, havendo verdadeiras filas que tornam o tempo de espera incerto. A menos deste inconveniente, o prazo de 
construção de uma usina tipo CCPS não excede 2 anos, enquanto uma térmica a óleo ou carvão equivalente leva em média 3 anos.

Os investimentos necessários são também menores. Uma usina a carvão, incluindo a unidade de desufurização dos gases de escape da chaminé (hoje exigência em todo o mundo) fica 80\% mais cara que uma CCPS equivalente. O gás usado, porém, deverá ser um produto de elevada qualidade, enquanto as outras térmicas podem lançar mão do carvão não tratado ou óleos combustíveis residuais, de custo menor. Não entraremos em discussão dos custos operacionais, porém podemos indicar que, graças ao não manuseio de combustível e ao alto grau de automação que se pode alcançar em uma CCPS, o número de operários é comparativamente pequeno em relação às térmicas tradicionais - em uma termelétrica a gás natural de ciclo combinado de 800 MW podemos esperar algo entre 30 e 60 homens.

É possível afirmar que as CCPS oferecem vantagens competitivas importantes sobre as convencionais. Tratando-se de uma tecnologia relativamente recente, há oportunidades abertas para melhoramentos, seja na eficiência térmica, seja na performance dos equipamentos envolvidos, tornando ainda mais atrativa a economia global deste tipo de empreendimento.

Na atualidade verificamos a preocupação dos grandes fornecedores de projetos que são entregues pronto para operar, também conhecido como turn key, um novo tipo de projetos de térmicas a gás natural de alta eficiência que podem ser uma energia de backup de resposta rápida para cobrir as cargas de energias do tipo solar ou eólica.

Já é possível encontrarmos usina térmica a gás natural de 510-megawatt “GE's FlexEfficiency 50”, com eficiência de $61 \%$ e que atinge a taxa de 51 megawatts em um minuto, de acordo com o fornecedor. 


\section{5}

\section{Impactos socioambientais nas térmicas a gás natural}

O objetivo da Política Nacional de Meio Ambiente, lei 6938/1981, está expresso no caput do art. 20:

\footnotetext{
“Art.20 A Política Nacional do Meio Ambiente tem por objetivo a preservação, melhoria e recuperação da qualidade ambiental propícia à vida, visando assegurar, no País, condições ao desenvolvimento socioeconômico, aos interesses da segurança e à proteção da dignidade da vida humana”.
}

Atendendo ao estabelecido na PNMA, foram criados instrumentos de proteção ao meio ambiente. Dentre eles está a exigência de elaboração de estudo de impacto ambiental para as atividades potencialmente poluidoras.

Alguns impactos ambientais são identificados na implantação e operação de Usinas Térmicas, tais como: alteração dos níveis de ruído e vibrações, assoreamento e alteração da qualidade da água dos corpos hídricos, alteração do lençol freático, alterações das características físicas e químicas do solo.

Entretanto, o mais discutido é a alteração na qualidade do ar proveniente da emissão de poluentes oriundos da queima de combustível.

Pela Figura 8, à seguir, pode-se verificar de forma esquemática alguns poluentes atmosféricos associados a efeitos negativos da atividade. 


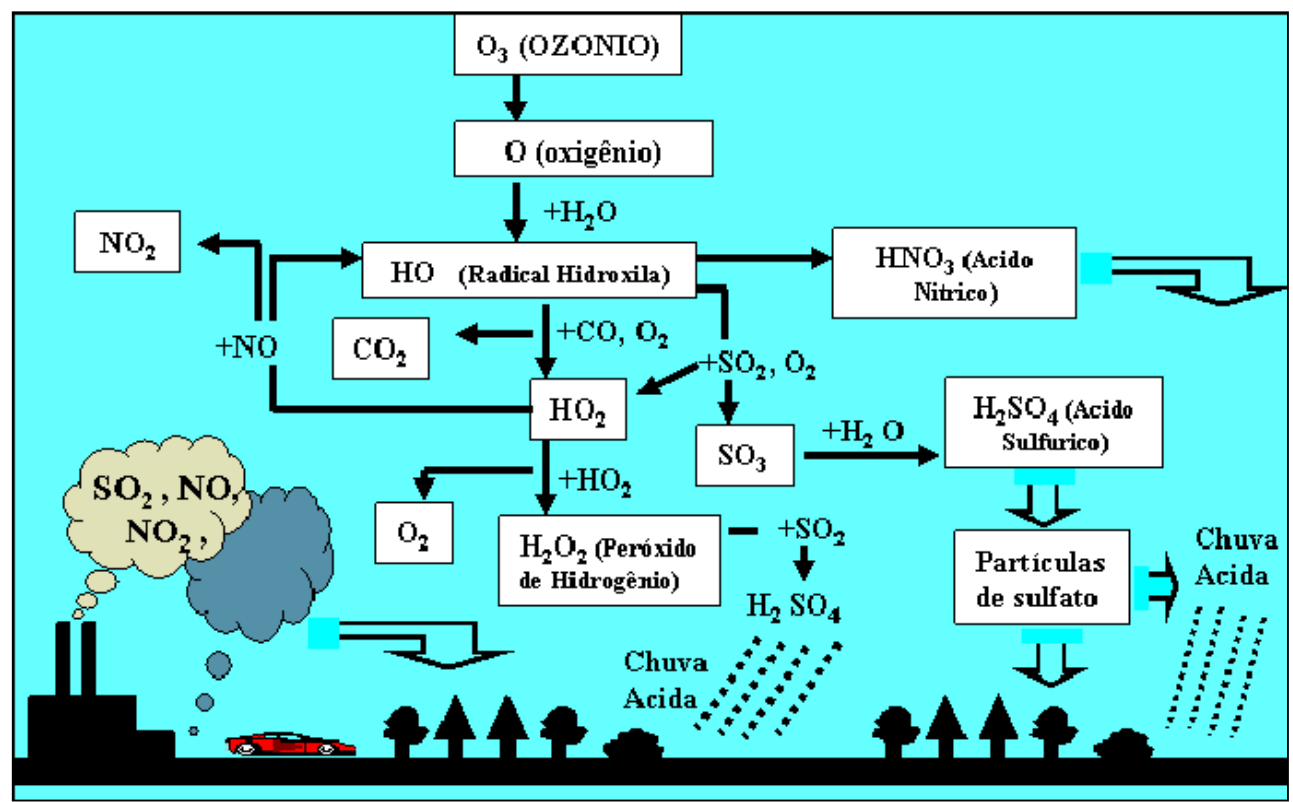

Figura 8 - Poluição aérea e suas consequências (Fonte: Lisboa, 2007)

De acordo com Magrini et al. (2001), entre os principais poluentes primários, que são emitidos diretamente da fonte poluidora para a atmosfera destacam-se:

a) Composto de Carbono (C): São gases poluentes sem cheiro, sem gosto e sem cor. São formados na queima incompleta de combustíveis que contém átomos de carbono. O $\mathrm{CO}$ e o $\mathrm{CO}_{2}$ são emitidos anualmente para a atmosfera pelas fontes antropogênicas no mundo (motores de veículos, queima de combustíveis fósseis para gerar eletricidade e calor, processos industriais, disposição de resíduos sólidos). $\mathrm{O}$ monóxido e o dióxido de carbono $\left(\mathrm{CO}\right.$ e $\left.\mathrm{CO}_{2}\right)$ podem causar o aumento da incidência de doenças/mal estar, podendo causar tonturas, dores de cabeça e redução dos reflexos. Caso a fonte emissora situe-se em locais fechados pode levar a morte por asfixia (PERES, NOGUEIRA, TORRES 2000).

b) Compostos de Nitrogênio ( $\mathbf{N})$ : A atmosfera apresenta naturalmente vários tipos de compostos de nitrogênio, dentre os quais se destacam: $\mathrm{N}_{2} \mathrm{O}$ (óxido nitroso), $\mathrm{NO}$ (monóxido de nitrogênio), $\mathrm{NO}_{2}$ (dióxido de nitrogênio), $\mathrm{NH}_{3}$ (gás-amoníaco), sais de $\mathrm{NO}_{3}-, \mathrm{NO}_{2}$ e $\mathrm{NH}_{4}$ (amônia). $\mathrm{O} \mathrm{NO}_{2}$ antropogênico é um gás incolor e é gerado principalmente 
pela combustão. O Nitrogênio e o Oxigênio estão abundantemente presentes na atmosfera onde reagem formando outros compostos. Os $\mathrm{NO}_{\mathrm{x}}$ causam uma série de doenças de origem respiratória, como por exemplo o enfisema pulmonar, a irritação e constrição das vias respiratórias.

c) Metano $\left(\mathbf{C H}_{4}\right)$ : O metano é o hidrocarboneto mais simples, sendo a primeira substância da série dos alcanos. É o principal constituinte do gás natural e como tal é uma importante matéria-prima na produção de outros compostos orgânicos. É formado pela decomposição de compostos orgânicos na ausência de oxigênio por determinadas bactérias, seja em pântanos, seja no estômago do gado, ou outros ruminantes. Fontes adicionais, induzidas pela espécie humana, são a queima de biomassa vegetal, vazamentos de dutos de gás natural, plantio de arroz em áreas alagadas, mineração de certo tipo de carvão mineral e lagos e reservatórios de hidrelétricas.

A emissão de gases e materiais particulados além de terem efeitos diretos na saúde dos seres vivos geram efeitos nocivos a diversas áreas dos ecossistemas naturais e urbanos.

Em conformidade com a NBR 8969/1985, a poluição do ar refere-se necessariamente a:

\begin{abstract}
“a presença de um ou mais poluentes atmosféricos” e Poluente Atmosférico "toda e qualquer forma de matéria e/ou energia que, segundo suas características, concentração e tempo de permanência no ar, possa causar ou venha a causar danos à saúde, aos materiais, à fauna e a flora e seja prejudicial à segurança, ao uso e ao gozo da propriedade, à economia e ao bem - estar da comunidade.
\end{abstract}

Dentre os poluentes atmosféricos existem ainda os poluentes secundários. São todos os poluentes formados na atmosfera a partir de reações químicas entre poluentes (poluentes primários). Entre os principais poluentes secundários tem-se:

- $\quad$ Ozônio Troposférico $\left(\mathrm{O}_{3}\right)$;

- $\quad$ Peróxido de Hidrogênio $\left(\mathrm{H}_{2} \mathrm{O}_{2}\right)$; 
- Aldeídos;

- $\quad$ Peroxiacetilnitrato (PAN);

- Ácido Sulfúrico $\left(\mathrm{H}_{2} \mathrm{SO}_{4}\right)$;

- Ácido Nítrico $\left(\mathrm{H}_{2} \mathrm{NO}_{4}\right)$

Segundo Magrini et al. (2001, p. 65), pode-se verificar que:

A atmosfera apresenta naturalmente uma determinada concentração típica de elementos/compostos químicos em sua composição, que em termos gerais, não afetam as condições normais de existência dos seres vivos e dos materiais, sendo alguns deles necessários à manutenção da biosfera. Nesse contexto, verifica-se que a poluição ambiental aérea consiste basicamente em uma acentuação ou incremento dos níveis destes elementos capazes de atingir concentrações nocivas ao meio ambiente.

Ainda, segundo Mota (1997), a poluição aérea pode gerar determinados problemas ambientais de caráter local, regional ou mesmo global, sendo que em relação aos referidos impactos ambientais locais, ressalta-se os seguintes: a) Efeitos negativos sobre a saúde das populações; b) Danos aos materiais e às construções; c) Alterações microclimáticas; e d) Danos aos animais e plantas.

Em relação, aos problemas ambientais de caráter regional ou continentais são caracterizados como sendo todos aqueles verificados a grandes distâncias das fontes emissoras (origem), sendo que um dos principais impactos regionais que se pode verificar, se refere à questão da acidificação da atmosfera, ou seja: deposição ácida ou chuva ácida.

Da mesma forma, Magrini et al. (2001, p. 65) ressalta que os problemas ambientais globais decorrentes da poluição aérea influem em determinados parâmetros de grande escala da atmosfera, pode-se ressaltar os seguintes: a) Efeito estufa (Aquecimento Global); b) Destruição da camada de ozônio.

No ar, a emissão para a atmosfera pelas chaminés das termelétricas, o $\mathrm{SO}_{2}$ sofre processos químicos na atmosfera causando fenômenos como a chuva ácida. Além, é claro da diminuição da visibilidade atmosférica. 
Apesar das vantagens relativas do gás natural comparado ao petróleo e ao carvão mineral, já que o gás natural é o combustível fóssil e não renovável cuja utilização gera a menor taxa de emissões, seu aproveitamento energético, também produz indesejáveis impactos ao meio ambiente.

No gás natural a produção de gás carbônico $\left(\mathrm{CO}_{2}\right)$ gerada por sua queima é significativamente baixa comparando-o aos demais combustíveis fósseis, já que ele é rico em hidrogênio $(\mathrm{H})$.

O que acentua mais o problema ambiental em uma térmica a gás natural, é o da emissão de óxidos de nitrogênio ou $\mathrm{NO}_{\mathrm{x}}$ e gás carbônico $\left(\mathrm{CO}_{2}\right)$. Uma turbina a gás possui níveis mais elevados de $\mathrm{NO}_{\mathrm{x}}$ do que caldeiras a óleo ou a carvão, porque a relação entre o ar e o combustível é muito maior na queima do gás. Para minimizar esse problema, vem se desenvolvendo tecnologias cujas quais através da injeção de água ou vapor na zona de combustão das turbinas vai se reduzir a emissão de $\mathrm{NO}_{\mathrm{x}}$ e elevar a capacidade produtiva da máquina.

Um dos maiores problemas é a necessidade de resfriamento, cujo fluído de resfriamento é normalmente a água. A crítica que se faz é que apesar na tecnologia estar ajudando a diminuir a quantidade de água utilizada nas usinas, grande quantidade se perde na evaporação, e o despejo dos afluentes também prejudica o meio ambiente (ANEEL, 2005). Mais de 90\% do uso de água de uma central termelétrica pode ser destinado ao sistema de resfriamento. Embora existam tecnologias de redução da quantidade de água necessária e mitigação de impactos, isso tem sido uma fonte de problemas ambientais, principalmente em relação aos recursos hídricos, em função do volume de água captada, das perdas por evaporação e do despejo de efluentes (BAJAY, WALTER e FERREIRA, 2000). 


\section{3 \\ GESTÃO AMBIENTAL}

\section{1}

\section{Conceito de gestão ambiental}

O campo da gestão ambiental é uma área muito ampla. Essa referida amplitude se esclarece em decorrência de que a questão relacionada ao meio ambiente necessita ser devidamente entendida em sua complexidade.

A busca de soluções passa, necessariamente pela revisão de modelos de desenvolvimento, abrangendo questões tecnológicas, industriais, econômicas, culturais, entre outras, todas relacionadas ao estilo de vida, altamente predatória das sociedades contemporâneas.

Deste modo, observa-se que os temas ambientais vêm ocupando um lugar respeitável entre as grandes preocupações do mundo moderno. Consentem estruturar uma espécie de radiografia da realidade, que, em decorrência aos problemas emergentes, demandam uma tomada de consciência e, especialmente, uma solução imediata para as mesmas (CAMPOS e LERÍPIO, 2007).

Os fundamentos, ou seja, as razões que conduzem as empresas a adotar e praticar a gestão ambiental são inúmeras. Sendo que a mesma pode decorrer a partir de procedimentos obrigatórios de atendimento da legislação ambiental até a definição de políticas ambientais que pendam a conscientização de todo o pessoal da organização.

É importante destacar que na realidade, a busca de determinados procedimentos gerenciais ambientalmente corretos, incluindo-se aí a adoção de um Sistema de Gestão Ambiental, na realidade, encontra diversos motivos que justificam a sua adoção. Nota-se que os fundamentos predominantes podem variar de uma organização para outra. 
Segundo Andrade et al., (2002), no entanto, eles podem ser resumidos nos seguintes parâmetros básicos:

a) Os recursos naturais, ou seja, a matérias-primas são limitados e estão sendo intensamente afetados pelos processos de utilização, exaustão e degradação derivados de atividades públicas ou privadas, por conseguinte estão cada vez mais escassos relativamente mais caros ou se encontram legalmente mais amparados legalmente;

b) Os bens naturais, ou seja, solo, água e ar, já não são mais bens livres/grátis, ou seja, a água possui valor econômico, ou seja, pagase, e cada vez se pagará mais caro por esse recurso natural. Nota-se que determinadas indústrias, principalmente com tecnologias avançadas, necessitam de áreas com relativa pureza atmosférica. Ao mesmo tempo, uma residência num bairro com ar puro custa bem mais do que uma casa em região poluída;

c) O crescimento populacional, principalmente nos grandes centros metropolitanas e nos países menos desenvolvidos, vem exercendo uma forte consequência sobre o meio ambiente em geral e os recursos naturais em especial;

d) A legislação ambiental demanda cada vez mais reverência e cuidado com o meio ambiente, exigência essa que conduza de forma coercitiva a uma maior preocupação ambiental;

e) Pressões públicas de cunho local, nacional e mesmo internacional demandam cada vez mais responsabilidades ambientais das empresas;

f) Bancos, financiadores e seguradoras propiciam maiores privilégios a empresas ambientalmente sadias ou aplicam taxas financeiras e valores de apólices mais elevadas de firmas poluidoras;

g) A sociedade em seu todo, bem como a vizinhança em particular está cada vez mais exigente e crítica no que se refere a danos ambientais e à poluição provenientes de empresas e atividades. Organizações não-governamentais estão cada vez mais atentas, demandando o cumprimento da legislação ambiental, a 
minimização de impactos, a reparação de danos ambientais ou ainda impedem a implantação de novos empreendimentos ou atividades sem o devido cuidado e licenciamento ambiental;

h) Compradores de produtos intermediários estão exigindo cada vez mais produtos que sejam produzidos em condições ambientais favoráveis, em muitos casos, solicitam o denominado selo verde;

i) As empresas ambientalmente saudáveis apresentam uma imagem mais aceita por acionistas, consumidores, fornecedores e autoridades públicas; dessa forma, os acionistas conscientes da responsabilidade ambiental preferem investir em empresas lucrativas sim, no entanto ambientalmente responsáveis.

Dessa forma, observa-se que a gestão ambiental empresarial está na ordem do dia, especialmente nos países descritos como altamente industrializados e também já nos países considerados em vias de desenvolvimento (PHILLIPPI JR, 2002).

\section{2}

\section{A Conscientização Ambiental e as Normas ISO 14000}

Em breve relato histórico sobre as preocupações ambientais e bem como a aparecimento da preocupação ambiental por parte da sociedade moderna e de empresários foi desenvolvido por Valle (1996), a qual se cita de forma resumida a seguir.

Na década de 1960, que um grupo de cientista denominado de Clube de Roma, empregando modelos matemáticos, as quais advertiram o mundo sobre os riscos intrínsecos ao crescimento econômico baseado nos recursos naturais esgotáveis.

Na década de 1970, ocorreu o inicio da estruturação dos organismos ambientais nos países industrializados, após a realização da Conferência de Estocolmo sobre o Meio Ambiente em 1972. Neste contexto, observa-se que a referida década foi definida como a década da regulamentação e do controle 
ambiental, onde foram elaboradas as legislações ambientais com a finalidade do controle da poluição.

Dessa forma, em 1972 foi publicado o relatório denominado "Limits to Growth" (Limites ao Crescimento), cujas projeções mais pessimistas sobre o futuro, embora não concretizado, tiveram a finalidade de conscientização da sociedade em geral sobre os limites de exploração abusiva da terra.

Entretanto, é importante observar que a crise energética gerada pelo aumento do preço do petróleo, em 1973, levantou a questão da racionalização do uso da energia e a busca de combustíveis alternativos, menos poluentes e de fontes renováveis. Desta forma, foi introduzido um conceito fundamental: a conservação da energia.

Nesse sentido Bursztyn et al. (2011), destaca que:

\begin{abstract}
Faz-se necessário, despertar as nações para a relação entre crescimento econômico, perdas ambientais e desenvolvimento científico e tecnológico. (...) Nessa época, entretanto, países da periferia viam na 'indústria da poluição' a opção segura que lhes restava para alcançar o desenvolvimento, trilhando o caminho já percorrido pelas nações desenvolvidas.
\end{abstract}

Em 1978, foi criado na Alemanha o primeiro selo ambiental, denominado de Anjo Azul, cuja finalidade era a de rotular os produtos considerados ambientalmente corretos.

Já na década de 1980, deram inícios aos primeiros Estudos de Impacto Ambiental e os Relatórios de Impacto sobre o Meio Ambiente (EIA/RIMA), visando o licenciamento e controle das instalações de novas indústrias e ainda, busca estabelecer exigências para as emissões das indústrias existentes. Em relação ao Brasil, a regulamentação dos EIA-RIMA ocorreu em 1986.

Por fim, a década de 1980 foi encerrada com a preocupação da conservação do meio ambiente de forma global.

Atualmente a gestão ambiental está-se tornando um tema obrigatório nas discussões dos executivos da empresa. Neste contexto, ressalta-se que a 
globalização dos negócios, a internacionalização dos padrões de qualidade ambiental trazidas pela ISO 14000 (NBR ISO 14001), onde a conscientização crescente da atual consumidora e a disseminação da educação ambiental nas escolas possibilitam prever as necessidades futura que poderão resultar em uma relação entre consumidores e a preservação do meio ambiente aliados à qualidade de vida a qual devera ser intensificada. Dessa forma, as organizações modernas deverão, de maneira acentuada, congregar a variável ambiental na prospecção de seus cenários e na tomada de decisão, além de sustentar uma postura responsável em relação à questão ambiental necessários para atingir a excelência (DEL RIO e OLIVEIRA, 2004).

O referido Desenvolvimento Sustentável foi definido como sendo aquele que, buscando atender às necessidades da geração atual, não compromete as possibilidades e o direito das futuras gerações atenderem às suas próprias necessidades. A mesma vem a se caracterizar como sendo: "um processo de aprendizagem social de longo prazo, balizado por políticas públicas orientadas por um plano nacional de desenvolvimento inter-regionalizado e intra - regionalmente endógeno” (BURSZTYN et al., 2011).

Buarque (apud BURSZTYN et al., 2011), destaca que o desenvolvimento sustentável é visto atualmente como uma proposta que tem como finalidade primordial uma modernidade ética, e não somente uma modernidade técnica, na proporção em ela:

Implica incorporar o compromisso com a perenização da vida ao horizonte da intervenção transformadora do 'mundo da necessidade'. Isto requer um acervo de conhecimentos e de habilidades de ação para a implementação de processos tecnicamente viáveis e eticamente desejáveis. Tal acervo constitui o conjunto das tecnologias da sustentabilidade ${ }^{4}$ que podem ser caracterizadas como saberes e habilidades de

\footnotetext{
4 As “tecnologias da sustentabilidade" são tecnologias de processos e produtos, não se configurando como unidades isoladas, mas sistemas totais, que incluem conhecimentos técnicos e científicos, procedimentos, bens e serviços e equipamentos, assim como os procedimentos de organização e manejo, devendo ser compatíveis com as prioridades sócio-econômicas, culturais e ambientais nacionalmente determinadas. Dependem diretamente da base científica. A pesquisa científica é o elemento de articulação das metas pluridimensionais do desenvolvimento sustentável sob padrões menos intensivos de utilização de recursos. As redes internacionais, nacionais, regionais e locais de colaboração entre grupos de pesquisa e desenvolvimento tem importância estratégica (BURSZTYN et al., 2011).
} 
perenização da vida, que se traduzem em ordenações sistematizadas de modos diferenciados de interação (por exemplo, processos de produção e circulação do produto, modos de organização social, padrões de ganho e processamento de informações, entre outros).

Observa-se que as limitações, subentendidas no conceito de desenvolvimento sustentável, reconhecem a necessidade de a tecnologia desenvolver soluções que preservem os recursos limitados atualmente disponíveis na Terra, possibilitando dessa forma renová-los, esta situação se refere necessariamente aos casos dos recursos naturais renováveis, na medida em que sejam necessários às futuras gerações. Observa-se que esse conceito trás a possibilidade do aparecimento de uma nova era de desenvolvimento econômico, viabilizado com políticas que mantenham e expandam a base dos recursos naturais sob a óptica de desenvolvimento, enquadradas nas lógicas da racionalidade econômica liberal.

Por fim, a racionalidade econômica subjugou o social, o cultural, o político e a natureza às consequências lógicas e indubitáveis do crescimento econômico, quando, na realidade, a esfera das atividades econômicas é parte das atividades humanas e, estas, estão incluídas nas dinâmicas da biosfera.

\section{3}

\section{Dos Benefícios do Sistema de Gestão Ambiental}

Observa-se que o sistema de gestão ambiental através da NBR ISO 14001, proporciona uma garantia de reconhecimento de adequação ambiental da empresa pelos diferentes atores envolvidos nos processos externos que interagem com a questão ambiental, ou seja: mercado de produtos e insumos, órgãos de fiscalização, agências de financiamento, imprensa especializada, comunidade e movimento ambientalista (MAIMON, 1999).

Dessa forma, a adesão de uma empresa à norma supracitada vai proporcionar, além de uma maior inserção da empresa no mercado internacional, vantagens organizacionais, redutoras de custos de operação, redução de acidentes 
e consequentemente uma maior competitividade. Assim, a inserção da empresa no mercado internacional está diretamente condicionada de forma crescente às exigências dos clientes em relação ao seu desempenho ambiental, como à discriminação política e econômica contra os poluidores, sejam eles empresas regiões ou países.

Em relação à sociedade, os resultados são observados na melhoria da qualidade de vida decorrente da minimização de impactos ambientais adversos e em uma redução do custo de controle de fiscalização, uma vez que a adesão das empresas ocorre necessariamente de forma voluntária.

Destaca-se ainda que a partir da década de 1990, a questão ambiental passou a ser prioritária na agenda das Nações Unidas, dos Organismos Multilaterais de Crédito, tais como a do Banco Mundial - BIRD, Fundo Monetário Internacional - FMI, Banco Interamericano de Desenvolvimento - BID e Organização Mundial do Comércio - OMC, além de propiciar amplas discussões entre blocos políticos e comerciais: União Européia, Mercosul, Nafta, etc. neste caso, o fortalecimento das Organizações Não Governamentais - ONGs, dedicadas a causas ambientais, viabilizou o nascimento de um novo canal de monitoramento e difusão de informações sobre problemas ambientais em todo o mundo (GONÇALVES, 2004).

Nesta trilha, o referido autor, cita ainda que o meio ambiente e a ecologia lideram o conceito de globalização que permeia os dias atuais, tendo garantido espaço na mídia e poder de conscientizar a população e pressionar por ações corretivas e retaliatórias de ordem política e econômica, sob a forma de restrição de mercados, deterioração da imagem, veto a financiamentos e até ingerência direta.

Analogamente, da responsabilidade ambiental surge o conceito de responsabilidade social (GRAJEW, 1999; OLIVEIRA, 2000), denotando a questão um sentido de obrigação para com a sociedade. Dessa forma, observa-se que a Responsabilidade Social pode assumir inúmeras formas, a saber: proteção ambiental, projetos filantrópicos e educacionais, fomento à organização da 
comunidade, equidade nas oportunidades de emprego, suporte de serviços sociais em geral, entre outros.

Para Donaire (1999), a justificativa para o sentido de responsabilidade social por parte da empresa fundamenta-se na liberdade que a sociedade concede à empresa para existir.

Maimon (1999) cita que nos países em desenvolvimento as empresas de maior inserção internacional, tais como as multinacionais, exportadoras, aquelas que dependem de financiamento externo, vêm incorporando as responsabilidades ambientais e sociais. No caso das empresas brasileiras, a difusão da conscientização e da formulação da política ambiental ocorrida na década de 1980, não se traduziu proporcionalmente em uma incorporação da atuação responsável.

Dessa forma, além dos problemas de capacitação institucional, a recessão que a economia brasileira atravessou na referida década de 1980, não favoreceu novos investimentos em equipamentos e processos, pois em sua grande maioria, as empresas se defrontaram com escassez de recursos financeiros, sem apoio oficial em face do esgotamento do modelo econômico.

Atualmente, as empresas passaram a se pronunciar mais intensamente sobre suas responsabilidades ambientais e sociais. Isto decorre do fato, em parte, se deve ao debate sobre a modernidade, que vem difundindo as práticas liberais na economia e impulsionando a inserção internacional em decorrência da globalização.

Já Donaire (1999) destaca que as responsabilidades ambientais e sociais, mensuradas apenas dentro da especificação legal, devem migrar para a conscientização ambiental e social (social and environmental responsiveness). Observa-se que este conceito pode ser definido como a capacidade de uma organização de responder antecipadamente às expectativas da sociedade em relação ao meio ambiente.

Nesse aspecto, a busca por procedimentos, mecanismos, arranjos e padrões de comportamento desenvolvidos pelas empresas marca aquelas que introduziram 
definitivamente em sua cultura valores ambientais. Refere-se a um conceito que sobrepuja as responsabilidades social e ambiental, medido através de valores morais de obediência aos preceitos da lei, viabilizando um posicionamento mais ético e amplo de resposta às questões sociais e ambientais que ultrapassem as relações de interesse direto da empresa.

De acordo com Drucker (apud DONAIRE, 1999), esse posicionamento impõe à alta administração a obrigatoriedade de direcionar as ações da empresa nos campos social e ambiental, que devem ter origem no topo das organizações.

A tabela, à seguir apresenta os benefícios estratégicos e econômicos da gestão ambiental para as empresas, conforme se observa.

Tabela 3 - Benefícios da gestão ambiental

\section{BENEFICIOS ECONÔMICOS}

Economia de Custos

- Economia decorrente à minimização do consumo de água, energia e demais insumos;

- Economias decorrentes a reciclagem, venda e aproveitamento de resíduos e minimização de afluentes;

- Redução de multas e demais sanções decorrentes de poluição.

Incrementos de receitas

- Aumento da contribuição marginal de "produtos Verdes" que podem ser comercializados a preços mais altos;

- Maior participação no mercado devido à inovação tecnológica e menos concorrências;

- Linha de novos produtos para novos consumidores;

- Aumento na demanda para produtos que contribuem para a redução da poluição.

\section{BENEFICIOS ESTRATÉGICOS}

- Melhoria da imagem institucional;

- Aumento da produtividade;

- Melhoria nas relações de trabalho;

- Criatividade para novos desafios;

- Acesso assegurado ao mercado externo;

- Melhor adequação aos padrões ambientais;

- Melhor relação com órgãos governamentais, sociedade e grupos ambientais;

Fonte: Adaptado de North, K. Environmental business management. (Genebra, 1992 apud Donaire, 1995). 


\section{4}

\section{Fatores relacionados à Implementação do Sistema de Gestão Ambiental}

Maimon (1999) destaca que a implantação de um Sistema de Gestão Ambiental em conformidade a norma NBR ISO 14001, representa um processo de mudança comportamental e gerencial na empresa, cuja implementação deve ser conduzida de modo participativo e integrado.

Dessa forma, para obtenção do sucesso desejado em sua implementação, é imprescindível que ocorra um consenso em todos os níveis hierárquicos da empresa quanto à sua importância, e que não represente uma imposição gerencial, devendo ocorrer uma integração das funções com responsabilidade de linha e comprometimento da alta direção da empresa.

Dessa forma, o êxito no estabelecimento do SGA depende necessariamente dos seguintes fatores, a saber:

a) Do comprometimento da alta direção da empresa;

b) Do envolvimento de todos os setores e pessoas responsáveis pela sua implementação;

c) Do Sistema de Gestão Ambiental refletir a Política Ambiental da empresa;

d) Do Sistema de Gestão Ambiental considerar os recursos humanos, físicos e financeiros necessários; e

e) Do Sistema de Gestão Ambiental ser dinâmico e sofrer revisões periódicas.

Assim como, cita-se a seguir uma relação dos fatores considerados de destaque para um efetivo sucesso na implementação do Sistema de Gestão Ambiental da ISO 14001 em uma empresa, conforme se observa:

a) Investimento no treinamento e na educação dos recursos humanos (D’AVIGNON, 1996; VALLE, 1996); 
b) Participação dos colaboradores e partes interessadas, bem como a comunicação estabelecida entre eles: estes fatores dizem respeito à disseminação dos compromissos definidos pela alta gerência entre funcionários, fornecedores, clientes, órgãos governamentais e não governamentais e a sociedade em geral, visando ao aperfeiçoamento de ações ambientais conjuntas, além da sensibilização e do envolvimento de todos os setores e pessoas responsáveis pela sua implementação, ou seja, de todos vinculados à organização (VALLE, 1996; D’AVIGNON, 1996; MAIMON, 1999);

c) Integralização de conceitos e práticas por todos os colaboradores (VALLE, 1996);

d) Integração da atividade produtiva com o meio ambiente, no planejamento global da empresa (D’AVIGNON, 1996; MAIMON, 1999);

e) Mudança do comportamento individual e coletivo na organização (D’AVIGNON, 1996; MAIMON, 1999);

f) Manutenção de um sistema de gestão ambiental que assegure, no mínimo, que suas atividades atendam à legislação vigente e aos padrões estabelecidos pela empresa. Na ausência de uma legislação específica, a empresa deverá pautar-se pelas melhores práticas de proteção ambiental disponíveis, tendo em conta os níveis exigidos por uma política ambiental mais abrangente (VALLE, 1996);

g) Exigência de que seus fornecedores disponham de produtos e componentes com qualidade ambiental compatíveis com a de seus próprios produtos (VALLE, 1996);

h) Desenvolvimento em pesquisas e desenvolvimento (P\&D), objetivando a promoção/aperfeiçoamento de tecnologias que reduzam os impactos ambientais e/ou o consumo de matériasprimas, água e energia (VALLE, 1996); 
i) Garantia de que seus resíduos são transportados devidamente, até o destino estabelecido, de acordo com as boas práticas ambientais (VALLE, 1996).

j) Incorporar a variável ambiental nas etapas de planejamento, construção, manutenção e operação de seus empreendimentos;

k) Buscar novas tecnologias, insumos economicamente viáveis e aperfeiçoar processos que minimizem os impactos no meio ambiente, visando à prevenção da poluição;

l) Utilizar de forma racional os recursos ambientais, considerando os preceitos do desenvolvimento sustentável;

m) Garantir o cumprimento da legislação ambiental, dos compromissos ambientais assumidos e de outros requisitos pertinentes;

n) Monitorar e avaliar periodicamente o seu desempenho ambiental, de modo a assegurar a melhoria contínua de seu Sistema de Gestão Ambiental.

\section{5}

\section{Evolução e repercussão no ambiente industrial}

Em relação ao Brasil, a gestão do meio ambiente vem a se caracterizar pela desarticulação dos diferentes organismos envolvidos, pela ausência de coordenação e pela escassez de recursos financeiros e humanos para gerenciamento das questões relativas ao meio ambiente.

Conforme destaca Andrade et al. (2002), essa situação é o resultado de diferente estratégias adotadas em relação à questão ambiental no contexto do desenvolvimento econômico do Brasil.

Observa-se que essas mudanças de orientação governamental, se consolidam por meio da publicação de várias leis, entre as que resultam na criação 
de diversos agentes de controle ambiental, tanto no âmbito estadual e municipal. Diante dos protestos crescentes da sociedade em geral contra os riscos de desastres ecológicos ou da deterioração da qualidade de vida, observa-se que os governos locais e nacionais são pressionados a implantar normas cada vez mais rigorosas de proteção e conservação (ANDRADE et al., 2002).

Por conseguinte, é importante destacar que as portas do mercado nacional e internacional, visando os lucros se abrem cada vez mais para as empresas que não poluem, poluem menos ou deixam de poluir (DUARTE, 2007).

Classicamente, observa-se que as exigências referentes à proteção ambiental eram consideradas um entrave ao crescimento da produção um obstáculo jurídico legal e portador de grandes investimentos e de difícil recuperação, por conseguinte, e considerado o fator de aumento dos custos de produção. Dessa forma, evidenciavam-se a patente despreocupação com os aspectos ambiental que podem traduzir-se no oposto, ou seja, (DUARTE, 2007):

a) Aumento de custos;

b) Redução de lucros;

c) Perda de posição no mercado;

d) Privação da liberdade; ou

e) Interrupção de atividades.

Atualmente, o Meio ambiente e sua proteção estão-se tornando oportunidades para abrir mercados prevenir-se contra restrições futuras quanto ao acesso a mercados internacionais.

Destaca-se que as respostas das organizações e empresas ao novo desafio ocorrem em três fases, muitas vezes superpostas, dependendo do grau de conscientização da questão ambiental dentro da empresa (KONDO, 2007):

a) Controle ambiental nas saídas,

b) Integração do controle ambiental nas práticas e processos industrial; e

c) Integração de controle ambiental na gestão administrativa. 
Nota-se que o controle ambiental passa a ser integrado nas práticas e processos produtivos, deixando de ser uma atividades de controle da poluição e passando a ser uma função da produção.

Entretanto a preocupação com o meio ambiente não param de crescer e acabou abrangendo o próprio mercado, redefinindo-se o mesmo com o estabelecimento de um verdadeiro mercado verde, que torna os consumidores tão temíveis quanto os próprios órgãos de proteção ao meio ambiente (TORRES, 2006).

Dessa forma, destaca-se que a proteção ao meio ambiente deixa de ser uma exigência sancionada com multas e penalidades e insere-se em um quadro de ameaças e oportunidades, aliada a própria permanência ou saída do mercado (TORRES, 2006).

Para Milaré (2011), a proteção ambiental deslocou-se uma vez mais, deixando de ser uma função exclusiva do setor produtivo e passa a ser também uma função da administração.

Tachizawa (2002, p. 45) destaca-se que:

\begin{abstract}
Essa referida atividade dentro da organização passou a ocupar o interesse dos presidentes e diretores e a demandar nova função administrativa na estrutura administrativa que pudesse abrigar um corpo técnico específico e um sistema gerencial especializado, com a finalidade de propiciar à empresa uma integração articulada e bem conduzida de todos seus setores e a realização de um trabalho de comunicação social e consciente.
\end{abstract}

\title{
3.6
}

\section{A questão ambiental sob o enfoque econômico}

Observa-se que somente recentemente a ciência econômica veio a se interessar pela questão relacionada à poluição, pois até então suas preocupações se referiam necessariamente às relações existentes entre o meio ambiente, considerados sob o ponto de vista dos recursos naturais e o processo de desenvolvimento (DONAIRE, 1999). 
Segundo Libanori (1990) observa-se que na década de 1970, a Economia tendia de forma significativa sobre as relações entre desenvolvimento econômico e o meio ambiente, por conseguinte, o conceito de desenvolvimento sustentável apresentava três vertentes principais, conforme se observa: a) Crescimento econômico; b) Equidade social e c) Equilíbrio ecológico.

Sob este enfoque, o conceito de desenvolvimento apresenta alguns pontos basilares que devem ser considerados de forma harmônica em relação ao crescimento econômico, maior percepção com os resultados sociais decorrentes e equilíbrio ecológico na utilização dos recursos naturais.

Na atualidade, as principais correntes econômicas, relativamente à questão de meio ambiente, incluem: os eco-desenvolvimentistas; os pigouvianos; os neoclássicos; e os economistas ecológicos.

Para Maimon (1999 ) O termo eco-desenvolvimentistas em sua forma mais embrionária denota transformar o desenvolvimento numa agregação positiva com a natureza, proposto que tenha por base o seguinte: justiça social, eficiência econômica e procedência ecológica.

Os pigouvianos são defensores do princípio poluidor pagador - a empresa deve pagar pelos danos causados ao meio ambiente e pelos recursos ambientais que utiliza, da mesma forma que paga pelos outros recursos;

Em relação aos denominados neoclássicos, o conceito de meio ambiente associa três aspectos, fundamentais, segundo Maimon (1999):

i. O meio ambiente é a fonte de matérias-primas empregadas como insumos nos processos de produção. Destaca-se que estes insumos podem ser renováveis e não renováveis.

ii. O meio ambiente absorve todos os dejetos e efluentes da produção e do consumo de bens e serviços, sendo que essa absorção pode ser total, parcial ou mesmo nula, a depender do nível de saturação do ecossistema. 
III. O meio ambiente desempenha outras funções como a de suporte à vida animal e vegetal, lazer e estética.

E finalmente, os economistas ecológicos, que tratam da transdisciplinariedade que estabelece relações entre os ecossistemas e o sistema econômico, procurando tratar a questão ambiental de forma sistêmica e harmoniosa, isto é, o foco principal é a relação do homem com a natureza e a compatibilidade entre crescimento demográfico e disponibilidade de recursos. 


\section{ASPECTOS LEGAIS E INSTITUCIONAIS}

\section{1}

\section{Legislação}

Em relação à legislação do setor elétrico, verifica-se que a mesma é longa e descompassada, atua sempre no efeito e poucas vezes na causa dos problemas, gerando amplas incertezas, pouca transparência e ausência de confiabilidade para os elos que compõem o negócio. A seguir é apresentada a legislação referente ao setor:

a) Lei $\mathrm{n}^{0}$ 9.433, de 8 de janeiro de 1997, instituiu a Política Nacional de Recursos Hídricos e criou o Sistema Nacional de Gerenciamento de Recursos Hídricos;

b) Lei 9.648, de 27 de maio de 1998, criou o Mercado Atacadista de Energia (MAE) e a figura do Operador Nacional do Sistema (ONS);

c) Decreto 2.335, de 6 de outubro de 1997, constituiu a Aneel e aprovou sua Estrutura Regimental;

d) a Resolução Aneel $\mathrm{n}^{0}$ 456, de 29 de novembro de 2000, estabelece, de forma atualizada e consolidada, as condições gerais de fornecimento de energia elétrica, em harmonia com o Código de Defesa do Consumidor (Lei 8.078, de 11 de setembro de 1990).

Cita-se, ainda, a Resolução ANEEL nº 94, de 30 de março de 1998, que definiu os limites de concentração nas atividades de distribuição e geração. No período entre 1999 e 2000, pode-se destacar o estabelecimento dos valores normativos, trazendo as condições a serem atendidas por distribuidores e geradores para celebrar esses contratos de longo prazo, garantindo: (a) a expansão do parque gerador e a modicidade das tarifas; (b) a conclusão do processo 
definidor dos montantes de energia e demanda de potência e das respectivas tarifas, de forma a viabilizar a assinatura dos contratos iniciais pelas empresas de geração e distribuição; (c) a nova regulamentação do livre acesso aos sistemas de transmissão e distribuição para os agentes de geração e os consumidores livres; (d) o estabelecimento de novos padrões de qualidade de serviços para as distribuidoras; (e) o estabelecimento de limites à concentração econômica, e (f) a homologação das regras de funcionamento do MAE.

Em maio de 2001, o governo adotou medidas emergenciais para reduzir o risco de que ocorresse um colapso na oferta de energia elétrica e criou a Câmara de Gestão da Crise de Energia Elétrica (CGCE), com o objetivo de propor e implantar medidas emergenciais para compatibilizar a demanda com a oferta, evitando interrupções intempestivas no suprimento.

Em 2007, o Governo Federal anunciou o Programa de Aceleração do Crescimento (PAC), amplamente difundido, com previsão de investimentos no setor elétrico para o triênio 2007-2010, visando, principalmente, evitar a ocorrência de “apagões”.

Atualmente, os Institutos que compõem o setor e suas atribuições legais são:

- Congresso Nacional, Conselho Nacional de Políticas Energéticas (CNPE) e Ministério de Minas e Energia (MME): estabelecimento de políticas e diretrizes para o setor elétrico;

- Ministério de Minas e Energia (MME) e Empresa de Pesquisa Energética (EPE): planejamento e garantia do suprimento de energia;

- Agência Nacional de Energia Elétrica (Aneel): órgão regulador e poder concedente:;

- Operador Nacional do Sistema Elétrico (ONS): supervisão, controle e operação dos sistemas; 
- Câmara de Comercialização de Energia Elétrica (CCEE): contabilização e liquidação das diferenças;

- Agentes de geração, transmissão, distribuição e comercialização: execução e prestação dos serviços:.

Considerando um cenário de forte integração entre mercados, o setor elétrico brasileiro, normatizado e estabelecido da maneira como está, cujo ambiente regulado demonstra condições favoráveis para seu desenvolvimento, desempenha papel de suma importância para o desenvolvimento da nação.

Dessa forma, pela literatura, são diversas as resoluções, portarias, decretos, além de regulamentações e notas técnicas existentes no país. É necessário ressaltar que as mesmas não são claras, apresentam falta de simplicidade e não focam nas ações futuras, além de terem uma postura reativa e poderem sofrer lobbies de entidades interessadas em favorecimentos de suas organizações (MOÍSES, 2007). Neste contexto, verifica-se que a parte legal é muito trabalhosa, visto envolver, além do enquadramento das portarias da ANEEL, os licenciamentos ambientais, outorgas, acesso à rede e negociação de excedentes e/ou compra de backup 5 .

\section{2 \\ O Licenciamento Ambiental}

A Constituição Brasileira, em seu artigo 225, parágrafo $1^{\circ}$ inciso IV, estabelece, como elemento condicionante do licenciamento de atividades potencialmente degradadoras do ambiente, a demanda de necessário prévio Estudo de Impacto Ambiental (EIA), atribuindo um "status" mais amplo às normas vigentes sobre a matéria desde a edição da Lei ${ }^{0}$ 6.938/1981, que instituiu a Política Nacional de Meio Ambiente (PNMA), com o objetivo de preservar, melhorar e recuperar a qualidade ambiental do País através do Sistema Nacional de Meio Ambiente (SISNAMA), além das Resoluções nº 001/1986 e nº 237/1997 do Conselho Nacional do Meio Ambiente (CONAMA) (BRASIL, 2010 e 2011d).

\footnotetext{
${ }^{5}$ Fornecimento de energia elétrica para manutenção das instalações -(MOÍSES, 2007).
} 
A composição do SISNAMA é atribuída pelo artigo $6^{\circ}$ da já menciona Lei Federal nº 6.938/1981 (BRASIL, 2011g) que dispõe:

Os órgãos e entidades da União, dos Estados, do Distrito Federal, dos Territórios e dos municípios, bem como as fundações instituídas pelo Poder Público, responsáveis pela proteção e melhoria da qualidade ambiental, constituirão o Sistema Nacional do Meio Ambiente SISNAMA, assim estruturado:

I- órgão Superior: O Conselho de Governo, com a função de assessorar o Presidente da República na formulação da Política Nacional e nas diretrizes governamentais para o meio ambiente e os recursos naturais;

II- órgão Consultivo e Deliberativo: O Conselho Nacional de Meio Ambiente - CONAMA - com a finalidade de assessorar, estudar e propor ao Conselho de Governo, diretrizes de políticas governamentais para o meio ambiente e os recursos naturais e deliberar, no âmbito de sua competência, sobre normas e padrões compatíveis com o meio ambiente ecologicamente equilibrado e essencial à sadia qualidade de vida;

III- órgão central: o Ministério do Meio Ambiente, dos Recursos Hídricos e da Amazônia Legal, com a finalidade de planejar, coordenar, supervisionar e controlar, como órgão federal, a política nacional e as diretrizes governamentais fixadas para o meio ambiente;

IV- órgão executor: o IBAMA - Instituto Brasileiro de Meio Ambiente e dos Recursos Naturais Renováveis, com a finalidade de executar e fazer executar, como órgão federal, a política nacional e as diretrizes governamentais fixadas para o meio ambiente; 
V- órgãos Seccionais: os órgãos e entidades estaduais responsáveis pela execução de programas e projetos e, pelo controle e fiscalização de atividades capazes de provocar a degradação ambiental;

VI- órgãos Locais: os órgãos e/ou entidades municipais responsáveis pelo controle e fiscalização destas atividades, nas suas respectivas jurisdições.

Observa-se que este procedimento, conforme disposto no artigo 19 do Decreto $n^{\circ} 99.274 / 1990$, que regulamentou as Leis Federais $n^{\circ} 6.902 / 1983$ e $n^{\circ}$ 6.938/1981, de obrigação do empreendedor, na apresentação do EIA e, do lado da administração pública, da outorga de atos administrativos, que receberam o nome de licenças ambientais, a saber:

I - Licença Prévia (LP), na fase preliminar do planejamento da atividade, contendo requisitos básicos a serem atendidos nas fases de locação, instalação e operação, observados os planos municipais, estaduais ou federais de uso do solo; (com validade máxima de 5 anos, conforme Resolução CONAMA 237/97)

II - Licença de Instalação (LI), autorizando o início da implantação, de acordo com as especificações constantes do Projeto Executivo aprovado (com validade máxima de 6 anos conforme resolução CONAMA n ${ }^{\circ}$ 237/97); e

III - Licença de Operação (LO), autorizando, após as verificações necessárias, o início da atividade licenciada e o funcionamento de seus equipamentos de controle da poluição, de acordo com o previsto nas licenças prévia e de instalação, (com prazo máximo de validade de 4 a 10 anos, conforme Resolução CONAMA 237/97) (CARDOSO DA CUNHA, 2011). 
Assim, o procedimento específico para o licenciamento de Usinas Termelétricas, conforme mencionado anteriormente encontra-se disciplinado pelas Resoluções do CONAMA no 001/1986 e $n^{\circ}$ 006/1987, ressaltando-se que o disposto no artigo $5^{\circ}$ desta última norma, destaca que: "No caso de usinas termelétricas a LP deverá ser requerida no início do estudo de viabilidade da usina; a LI deverá ser obtida antes da efetiva implantação do empreendimento e a LO depois dos testes realizados e antes da efetiva colocação da usina em geração comercial de energia.”

Entretanto é importante salientar que mesmo que a empresa e órgão ambiental tenham seguido todas as diretrizes e padrões normais para licenciamento, o empreendimento pode sofrer impactos não previstos, de caráter jurídico.

Poderá haver intervenção do Ministério Público no sentido principal da prevenção do dano ambiental associado à implantação do empreendimento. Além disso, a defesa do meio ambiente pelo Poder Público é um dever constitucional. Observa-se que este dever estende-se aos particulares que, na qualidade de concessionários, assumem a prestação de serviços e obras públicas fundamentais (PÖYRY, 2008)

Como exemplo, podemos citar a questão da inserção jurídica já foi vivenciada pelo próprio setor elétrico e pelas estatais que detinham suas concessões, em função de que o Ministério Público Estadual ou Federal, em inúmeros casos e em diversas regiões do país, determinou a abertura de Inquéritos Civis e Ações Civis Públicas objetivando apurar possíveis danos gerados ao meio ambiente, fundamentado em denúncias da Mídia, de ONG’s ambientalistas e de diferentes segmentos sociais ambientalmente molestados pelas suas obras, sendo esta experiência de amplo significado para os produtores privados, enquanto cautela necessária, levando em consideração a expressa possibilidade de rescisão do Contrato de Concessão em casos de danos e infrações ambientais que porventura vierem a dar causa (PIRES, 2005). 


\section{3}

\section{Licenciamento Ambiental de Usinas Térmicas}

Ressalta-se que o licenciamento ambiental é um procedimento jurídico administrativo caracterizado como um dos instrumentos da Política Nacional de Meio Ambiente.

Sendo inserido no ordenamento jurídico pátrio, a princípio pela Lei $\mathrm{n}^{\circ}$ 6.803/1980 e, posteriormente, convalidado pela Lei ${ }^{\circ}$ 6.938/1981 (BRASIL, 2011).

As usinas de geração de eletricidade, qualquer que seja a fonte de energia primária, acima de $10 \mathrm{MW}$, é uma atividades considerada potencialmente degradadora do meio ambiente e encontra-se sujeita ao licenciamento ambiental. Esta obrigatoriedade está explicitado na Resolução CONAMA nº 001/1986, e corroborado pela Resolução CONAMA n 237/1997, em seu Anexo I, que atribui uma redação mais abrangente, relacionando os empreendimentos energéticos como Serviço de Utilidade, sem referência à sua capacidade de produção, seja para a produção de energia elétrica, seja para sua transmissão (PÖYRY, 2008).

Neste ponto, deve-se ressalta que a licença ambiental é insubstituível e indispensável para a instalação e operação de qualquer atividade real ou potencialmente poluidora, sem detrimento de outras licenças legalmente exigíveis, emitidas por outros órgãos federais, estaduais ou municipais. Nesse sentido, observa-se que essa característica, em muitos casos, intrínseca ao espírito do licenciamento ambiental, presumem um relacionamento biunívoco Estado/administrado.

Ademais, verifica-se que a expedição da licença representa unicamente uma formalização de um compromisso firmado entre o empreendedor e o Poder Público, sendo que se encontra de um lado, o responsável pelo empreendimento, o qual se compromete a implantar e operar a sua atividade segundo as condicionantes constantes da licença; em contraposição, posiciona-se o órgão licenciador que avaliza, durante o prazo de vigência da licença, desde que necessariamente cumpridas as condições nela expressas. Entretanto, deve-se 
destacar que não há direito adquirido para poluir e se ajustes forem necessários o Ministério público poderá e deverá fazê-los para proteger a saúde pública e o meio ambiente ainda que tais medidas impliquem necessariamente na possibilidade do empreendedor vir a discutir eventuais indenizações (CARDOSO DA CUNHA, 2011).

Outro elemento imprescindível para o licenciamento ambiental, se refere ao EIA, onde se verifica os critérios básicos e diretrizes gerais de formulação normatizada pela Resolução CONAMA $n^{0}$ 001/86, cuja premissaée necessariamente avaliar os impactos positivos e negativos gerados pela exploração de atividades tidas como potencialmente geradora de significativa degradação do meio ambiente e demonstrar quais são as medidas mitigadoras que deverão ser incorporadas ao empreendimento, conforme previsto no artigo 225, parágrafo $1^{\circ}$, Inciso IV da Constituição Federal (BRASIL, 2010)

Da mesma forma, encontra-se determinado no anexo da Resolução CONAMA nº 006/1987 que são necessários e imprescindíveis ao licenciamento ambiental os seguintes documentos: 
Tabela 4 - Documentos imprescindíveis ao licenciamento ambiental

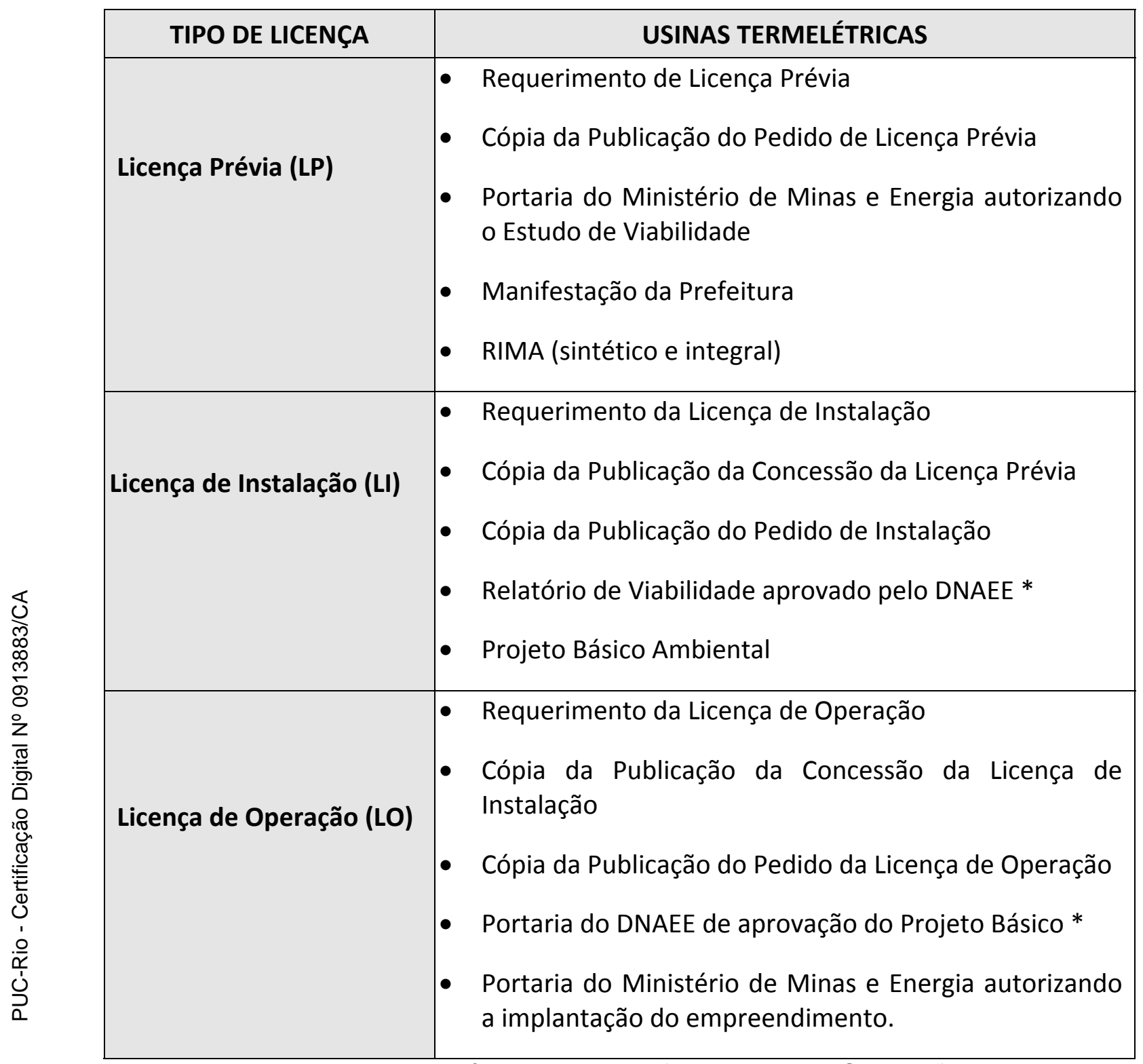

* Portarias do DNAEE substituídas por autorizações e Termos de Concessão da ANEEL

Deve-se ressaltar que a Resolução CONAMA n ${ }^{0}$ 237/1997, em seu artigo 10 parágrafo $1^{\circ}$ determina que a abertura do procedimento de licenciamento deverá se dar com a caracterização do empreendimento (descrição da engenharia) constando obrigatoriamente: certidão da Prefeitura de tipo de empreendimento ou atividade estando em conformidade com a legislação municipal de uso e ocupação do solo; autorização para supressão de vegetação (se for o caso); e a outorga do direito de uso da água. 
Algumas legislações específicas como a RESOLUÇÃO Nº 436, DE 22 DE dezembro DE 2011, que estabelece os limites máximos de emissão de poluentes atmosféricos para fontes fixas instaladas ou com pedido de licença de instalação anteriores a 02 de janeiro de 2007. Devem ser consideradas de maneira imediata pelos empreendedores. 


\section{5 \\ CARACTERIZAÇÃO TÉCNICA DA USINA TÉRMICA MACAÉ}

5.1

Introdução e caracterização do Empreendimento

O estudo de caso é baseado na Usina Térmica Macaé, com capacidade máxima de geração de 928,7 MW de potência bruta, criada com o principal objetivo de aumentar a garantia de fornecimento de energia elétrica aos estados do Rio de Janeiro e Espírito Santo, especialmente quando se considera que o norte do Rio de Janeiro e todo Espírito Santo, muito embora integrados ao sistema unificado brasileiro, estavam posicionados de tal forma que dependiam de apenas um ramal abastecedor, com escassas possibilidades de serem atendidos por algum remanejamento caso ocorresse algum dano ao ramal citado.

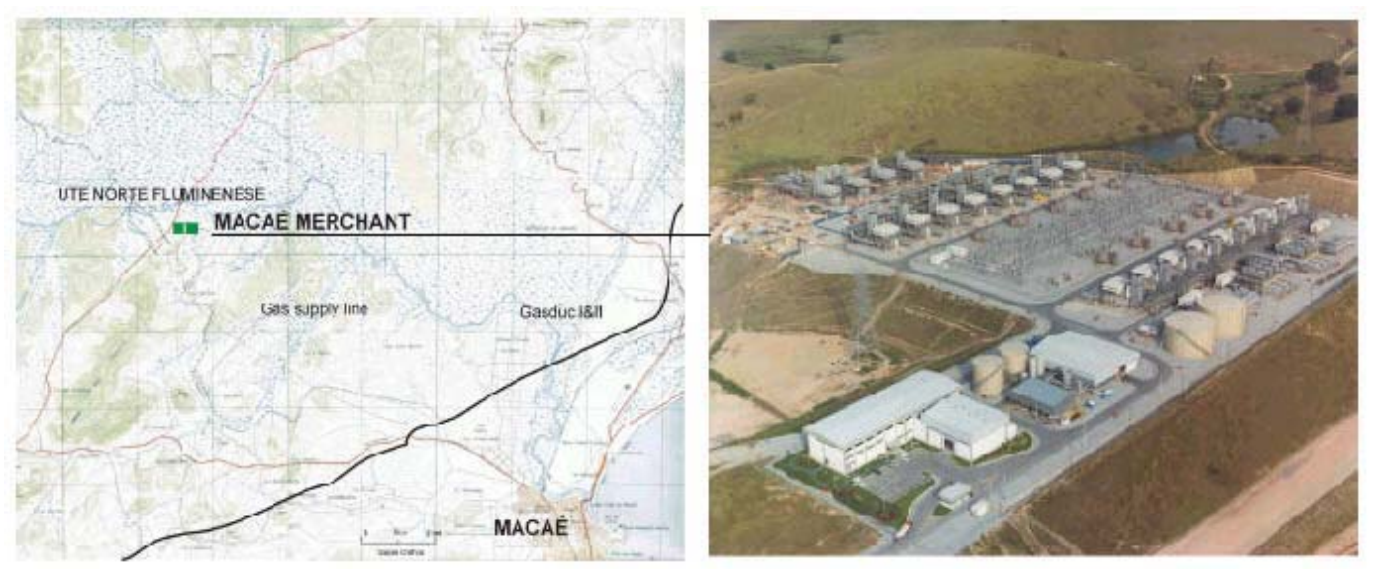

Figura 9 - Localização Regional e Foto Aérea Construção 2001 


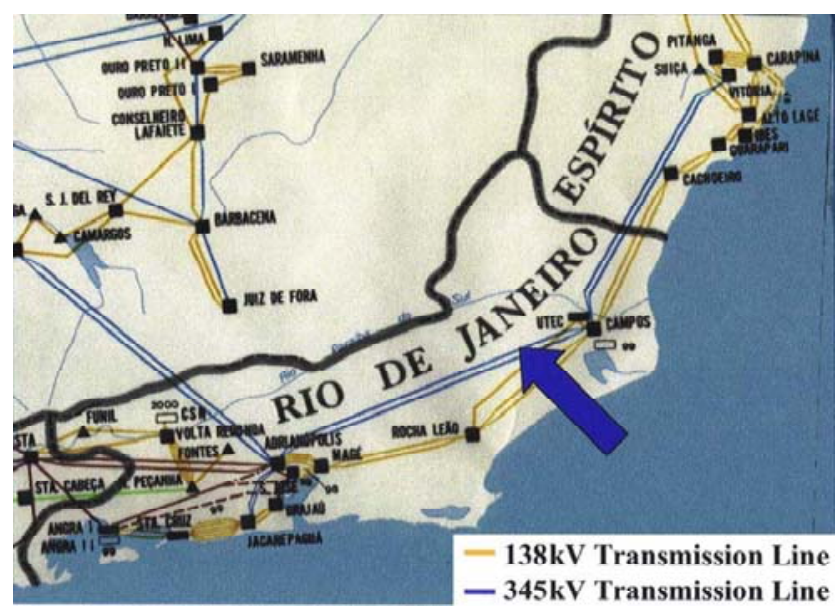

Figura 10 - Configuração da transmissão no sistema interligado sudeste-sul-centro oeste

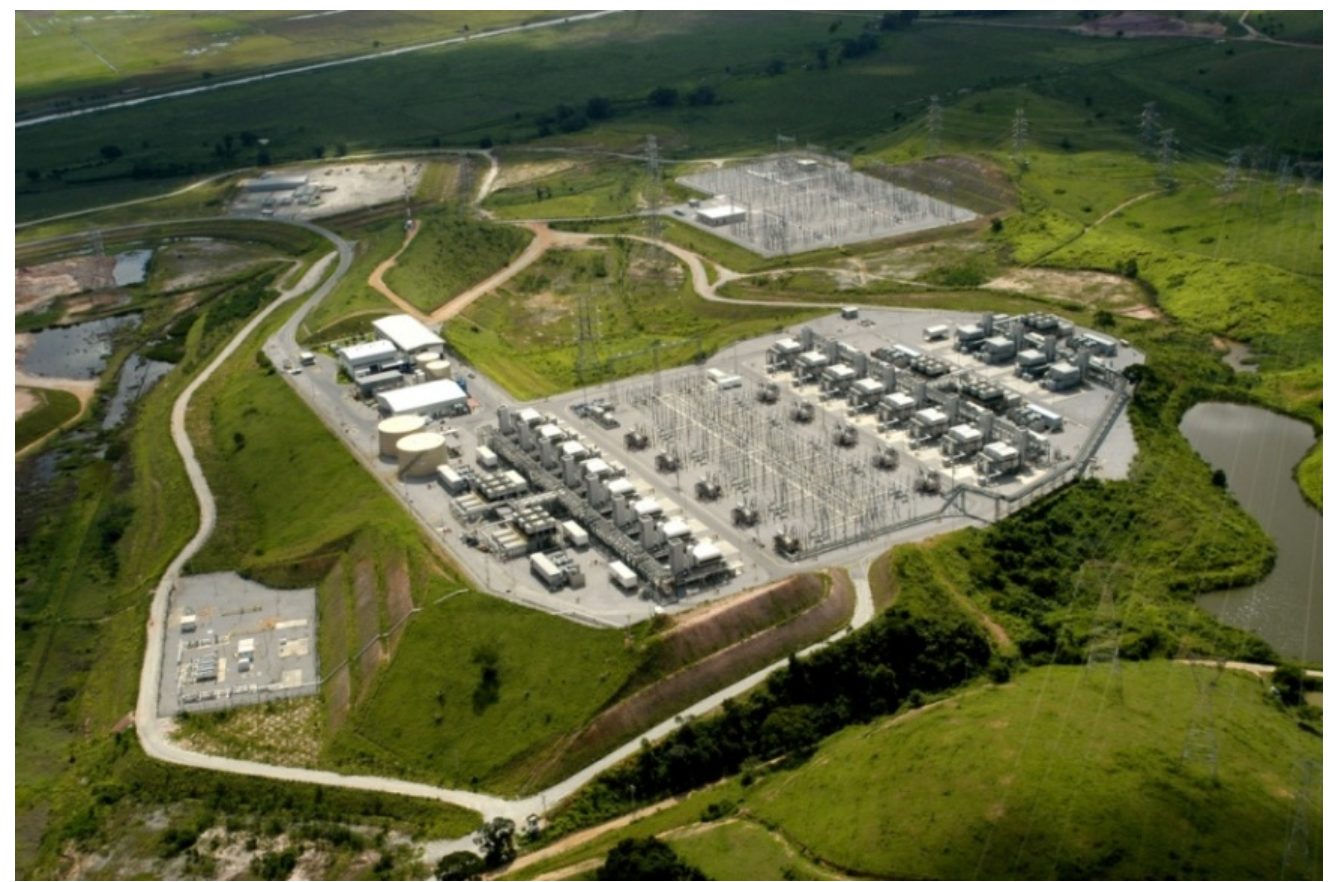

Figura 11 - Layout da usina implantada - 2002 


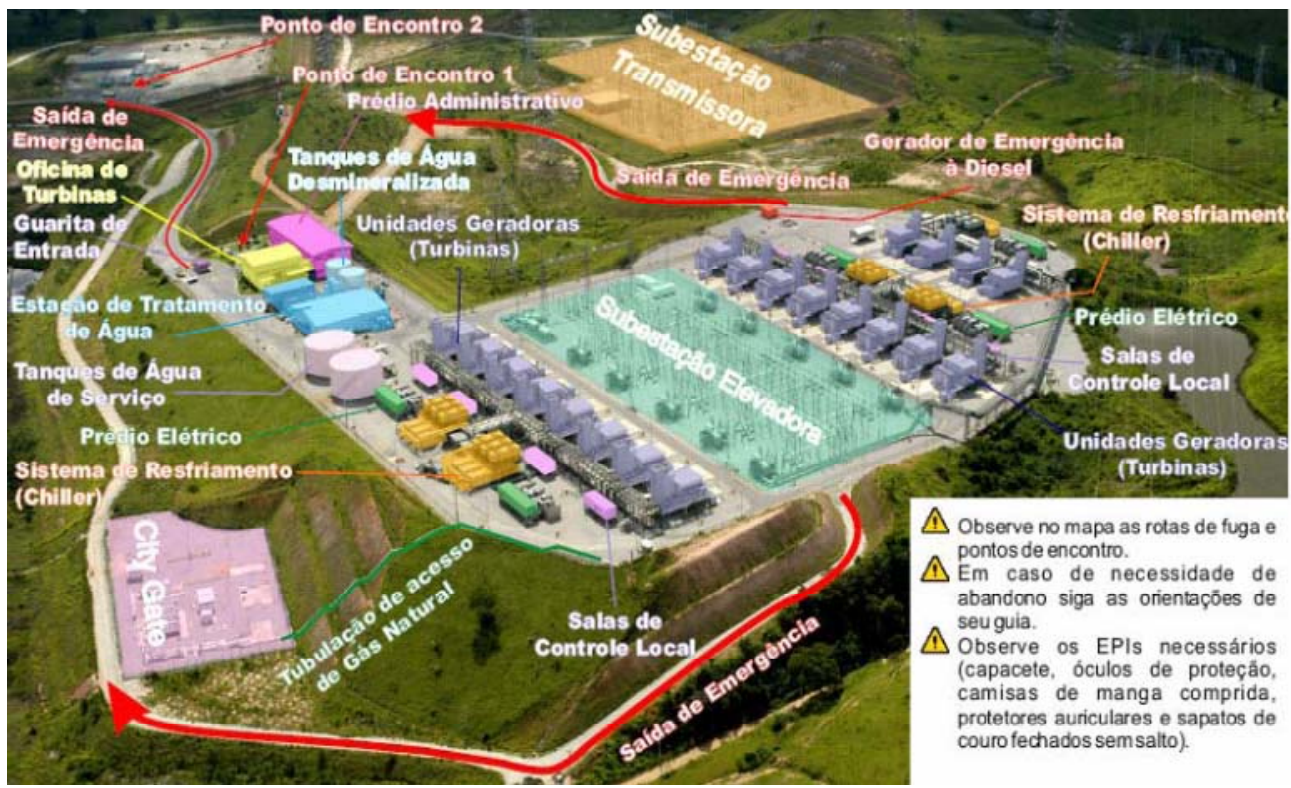

Figura 12 - Layout da usina com devidas identificações - 2002

A possibilidade de ocorrência de racionamento de energia no Brasil aumentava a cada dia, visto que as demandas crescentes eram cada vez mais reprimidas, face a incapacidade do estado de dispor dos montantes necessários para implantação de usinas na velocidade necessária para atendimento do mercado.

Em face desta real possibilidade, os governos estaduais da época se empenharam em aumentar a geração local de energia, incentivando a implantação de usina termelétrica e com isso aumentar o grau de confiabilidade do sistema de fornecimento de energia na região.

A instalação da unidade de geração trouxe benefícios pra região, tais como:

- Aumento na capacidade de geração no Sistema Interligado Sul/SE/Centro-Oeste, com redução do risco de racionamento de energia elétrica;

- Aumento de confiabilidade do abastecimento de energia para o Norte do Estado do Rio de Janeiro e todo o Espírito Santo;

- Utilização de um combustível que era queimado nas plataformas;

- Utilização da forma mais limpa de energia, comercialmente existente;

- Geração de novos negócios e renda para o Estado do Rio de Janeiro; 
- Oportunidade de utilização do parque metal mecânico e de serviços disponível de Macaé;

- Aumento da arrecadação municipal, dentre outros.

Para efeito de bem caracterizar o estudo de caso, Gestão Ambiental da Usina Termelétrica Macaé, são descritos abaixo os diversos aspectos relacionados à unidade, destacando-se as suas características básicas e tecnologias da UTE.

A Usina Termelétrica Macaé é do tipo ciclo simples, com capacidade máxima de geração de $860 \mathrm{MW}$, composta por 20 unidades geradoras compostas por turbina a gás com potência unitária de 43MW projetadas para uso de gás natural, cada uma delas diretamente acoplada a um gerador resfriado a ar. Os terminais dos 20 geradores são conectados a 10 transformadores elevadores principais, sendo um transformador para cada dois geradores.

A unidade é conectada ao sistema interligado Sudeste- Sul-Centro Oeste na linha de $345 \mathrm{kV}$ pertencente a FURNAS, através de subestação implantada no local.

\section{2}

\section{Descrição do processo de geração}

A UTE Macaé utiliza turbinas de combustão onde o ar e os produtos da combustão são os fluidos de trabalho termodinâmicos. O ar atmosférico é comprimido antes de entrar no combustor, onde é misturado com o combustível gás natural e então queimado.

Os produtos da combustão, com alta pressão e temperatura, passam pela turbina, onde geram energia mecânica para acionar o gerador.

A tecnologia de turbinas de combustão têm elevado a eficiência destes equipamentos à faixa de $30 \%$ a $35 \%$, próximas, portanto, da eficiência apresentada pelas turbinas a vapor. Essa eficiência está limitada principalmente pela energia contida nos gases de exaustão da turbina, que invariavelmente se 
encontram em altas temperaturas (entre $480^{\circ} \mathrm{C}$ e $650^{\circ} \mathrm{C}$ ). Esta energia é descarregada para a atmosfera, sem ser aproveitada.

As usinas que operam segundo este arranjo são ditas de ciclo simples e, normalmente, são usadas para operação em pico ou como reserva.

Com a utilização do o gás natural como combustível na UTE Macaé, selecionou-se a turbina GE LM6000 tendo em vista que, na faixa de potência entre 40 e 70MW, ela apresenta o menor consumo específico de calor (CEC) por kWh gerado.

\section{3}

\section{Caracterização dos insumos básicos}

Há dois insumos principais para a operação da Usina Termelétrica Macaé: o gás natural e água.

\subsection{1}

\section{Gás Natural}

Na operação da usina podem ser consumidos diariamente três milhões de metros cúbicos de gás natural provenientes da Estação de Cabiúnas da fornecedora e que são transportados para a usina através do gasoduto dedicado a ser implantado pela empresa empreendedora e operado pela companhia de gás local. Estes números podem variar de acordo com o despacho de energia da unidade.

O gás natural, classificado como do grupo $\mathrm{M}$ (médio), atende às seguintes especificações seguindo normas da ANP: 
Tabela 5 - Características do gás natural

\begin{tabular}{|c|c|c|}
\hline CARACTERÍSTICAS & UNID. & GRUPO M \\
\hline $\begin{array}{c}\text { Poder calorífico superior } \\
\text { (PCS) }\end{array}$ & $\mathrm{kcal} / \mathrm{m} 3$ & 8000 a 9000 \\
\hline $\begin{array}{c}\text { Densidade relativa } \\
\text { (H2S) max. }\end{array}$ & $\mathrm{mg} / \mathrm{m} 3$ & 0,55 a 0,69 \\
\hline $\begin{array}{c}\text { Teor de Gás Sulfídrico } \\
\text { enxofre mercaptílico) } \\
\text { max }\end{array}$ & $\mathrm{mg} / \mathrm{m} 3$ & 20 \\
\hline $\begin{array}{c}\text { Teor de Dióxido de } \\
\text { Carbono (CO2), max. }\end{array}$ & mg/m3 & 80 \\
\hline Teor de Inertes, max. & \% volume & 4 \\
\hline $\begin{array}{c}\text { Teor de Oxigênio (O2), } \\
\text { max. }\end{array}$ & C & 0,5 \\
\hline $\begin{array}{c}\text { Ponto de orvalho de } \\
\text { água, } 1 \text { atm, max. }\end{array}$ & & -45 \\
\hline
\end{tabular}

Embora nas especificações acima esteja indicado um teor de enxofre máximo de 80mg/m3, o gás processado em Cabiúnas pela fornecedora tem sido considerado pela companhia de gás como de teor nulo.

\section{3 .2}

Água

Havia duas opções para a liberação do ciclo de calor: o sistema aberto de refrigeração e o sistema fechado, empregando torres de refrigeração.

Durante muitos anos o sistema aberto de refrigeração foi o mais utilizado. No entanto, pelas restrições crescentes às descargas térmicas nos corpos de água, bem como pela necessidade de garantia de grande quantidade de água para o circuito de refrigeração, o uso de sistemas fechados com torres de refrigeração vem aumentando. Tal sistema requer menor quantidade de água e apresenta baixo impacto na temperatura do corpo de água, uma vez que a maior parte da energia térmica é dissipada sob a forma de evaporação da água.

Seguindo esta tendência, a UTE Macaé utiliza o sistema fechado com torres de refrigeração, razão pela qual serão captados no máximo 86 l/s do rio 
Macaé, cuja vazão mínima de 7 dias é de 4.870 l/s conforme dados do "Plano Diretor da CEDAE para Abastecimento de Água da Região dos Lagos, Macaé e Casimiro de Abreu”. É previsto um retorno oriundo dos efluentes do processo de desmineralização totalizando $4 \mathrm{l} / \mathrm{s}$ além de $8 \mathrm{l} / \mathrm{s}$ provenientes do ciclo e refrigeração. A vazão total que retorna ao rio Macaé é de 12 l/s.

\section{4}

\section{Características operacionais e de projeto}

A UTE Macaé está apta para operação em regime de carga base e condições cíclicas, com um fator de disponibilidade médio garantida de $90 \%$. O projeto contempla critérios ao nível de redundâncias em sistemas de instrumentação e controle, proteção e equipamentos reserva, de forma a obter o nível de confiabilidade ótimo e desejável para conexão ao sistema integrado de transmissão em 345kV.

Durante a operação normal, a carga pode ser variada mediante operação de uma ou mais turbinas a gás em regime de carga parcial e/ou através colocações em serviço ou retiradas de unidades de operação. Considerando que a operação das unidades turbo geradoras em baixa carga implica em sensível redução na eficiência, não é economicamente recomendável a operação da planta em regimes de baixos carregamentos. A seguir, são apresentados de forma simplificada os principais equipamentos e sistemas integrantes da Usina Termelétrica Macaé.

\section{4 .1}

\section{Grupo Turbina - Gerador}

As turbinas são do tipo GE LM 6000, consistindo de conjuntos de turbinas a gás com eixo aero-derivado, divididos em três componentes principais colocados sobre o CF6-80C2, conjunto de elevada eficiência como o acionador primário direto acoplado direto a um gerador de resfriamento a ar. Estas unidades operam em ciclo simples a gás natural utilizando injeção a água para controle do NOx. 
O controle de NOx é feito dentro da seção de combustão da turbina com a injeção de água desmineralizada. A água promoverá a redução da temperatura adiabática da chama minimizando a produção de NOx.

Cada turbina a gás é equipada com um exaustor de saída axial para facilitar a montagem em linha da chaminé de saída. Silenciadores de supressão de ruído serão instalados dentro do duto de exaustão para reduzir o impacto audível às áreas circunvizinhas. A elevação da chaminé será otimizada para minimizar o custo principal da instalação e ainda ter uma altura suficiente para permitir uma dispersão de descarga suficiente para atender os regulamentos ambientais brasileiros.

A turbina é acoplada diretamente ao gerador através de um acoplamento flexível metálico. O gerador, resfriado a ar, operará a 3600rpm, 13,8kV, 60Hz, e será capaz de manter a potência plena contínua da turbina a gás, dentro da faixa de temperatura projetada. Será utilizado um sistema de excitação sem escova com um imã permanente. A regulação da voltagem, sincronização, e o fator de potência são controlados pelo Painel de Controle da Turbina. Os mancais do gerador são protegidos através de um sistema lubrificado a óleo, montado externamente resfriado a água, operando em loop. Cada gerador é conectado ao transformador elevador através de uma barra que será conectada ao anel de barras do pátio de manobras.

A turbina e o gerador são acondicionados em invólucros acústicos impermeáveis. O compartimento da turbina é totalmente ventilado com ventiladores redundantes, enquanto que o compartimento do gerador é ventilado por um ventilador montado no eixo do gerador. Ambos os compartimentos são equipados com um sistema de iluminação a prova de explosão, assim como são protegidos pelo sistema automático de supressão de incêndio (CO2). Além da proteção a exposição ao tempo, os invólucros da turbina e do gerador garantem que o ruído em áreas próximas fique limitada a 90dbl. 
A foto mostrada abaixo ilustra a turbina do tipo GE LM 6000



Figura 13 - Turbina do tipo GE LM 6000

Fonte: http://www.turbinetechnics.com/ge-Im-6000-turbine

O gerador da turbina é uma máquina síncrona de ar refrigerado, com fator de potência de 0,85 atrasado a 0,95 adiantado, fornecidos pela Brush e $\mathrm{ABB} /$ Alstom. É acoplado diretamente à turbina de gás. O gerador tem isolamento classe $\mathrm{F}$ e aumento de temperatura limitado à classe $\mathrm{B}$, com potência máxima de 70 MVA, $13.8 \mathrm{kV}, 3600 \mathrm{RPM}, 60 \mathrm{HZ}$ a $15^{\circ} \mathrm{C}$.
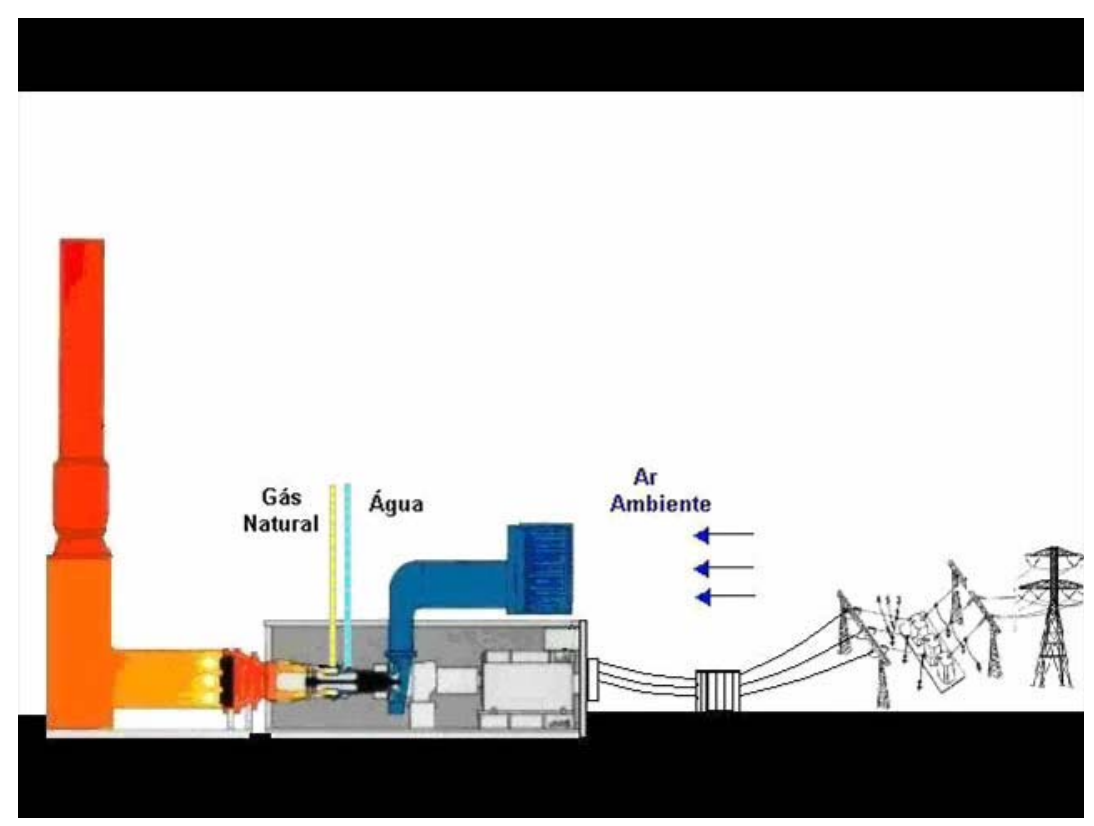

Figura 14 - Modelo esquemático dos insumos para geração térmica a gás natural 


\section{4 .2}

\section{Sistemas elétricos}

Sistema de Alta Tensão: A usina tem uma subestação de elevação ou da geração, que está conectada à subestação de conexão, a qual se conecta com o Sistema Elétrico Interligado através das linhas de transmissão de $345 \mathrm{kV}$ Adrianópolis- Campos de FURNAS

Alimentação do Sistema de Média Tensão: A cada par de geradores, há um transformador auxiliar abaixador de 13,8/4,16 kV - 10/12,5 MVA conectado ao barramento de um dos geradores, que alimenta o sistema de Serviços Auxiliares da usina e consequentemente, o sistema de média tensão. Sendo a cada par de geradores um transformador conectado, temos 10 transformadores como descrito acima.

Sistema de Serviço Auxiliar da Usina (média tensão): Dez unidades de transformadores auxiliares mantém o sistema de média tensão da usina a 4.16 kV. O sistema de distribuição de média tensão da usina alimenta os auxiliares da usina (ex.:compressores das unidades de resfriamento) e fornece energia ao sistema de distribuição de baixa tensão da usina por meio de transformadores de serviço (transformador abaixador 4,16 kV / $480 \mathrm{~V}$ ).

Sistema de Baixa Tensão: O sistema de baixa tensão da usina é alimentado por transformadores de serviço abaixadores de 4,16 kV / 480 V (220$127 \mathrm{~V})$.

Gerador de Emergência: A energia de emergência é fornecida por um motor-gerador diesel de emergência utilizado para esse fim, o qual está conectado ao barramento essencial por um disjuntor de transferência automática. Cargas que são tipicamente alimentadas pelo barramento essencial são:Fornecimento Não Interrompível (UPS); Carregador de Bateria para cada Sistema Corrente Contínua; Iluminação de Emergência. 


\section{4 .3}

\section{Sistemas Auxiliares do Grupo Turbina - Gerador}

Compreendem os sistemas de combustível, de admissão de ar, de óleo lubrificante, de resfriamento do ar de entrada nas turbinas e de injeção de água nas turbinas para controle do NOx descritos a seguir:

Sistema de Combustível: utiliza compressores localizados nos limites da usina para elevar e estabilizar a pressão do gás natural, a 46,5bar(g), o que garante o fornecimento do gás para a turbina a uma pressão constante para todas as faixas de carga;

Sistema de Óleo Lubrificante: composto de dois sistemas de óleo separados, um para a turbina a gás e um para o gerador.

Sistema de Admissão de Ar: para permitir que a turbina disponha de ar limpo e filtrado para combustão e ventilação, será montado sobre os invólucros da turbina e do gerador um sistema de entrada de ar.

O fluxo no compartimento de ar é subdividido em dois, sendo um destinado para a combustão do ar na turbina a gás e um outro fluxo cujo propósito é ventilar os compartimentos da turbina e do gerador;

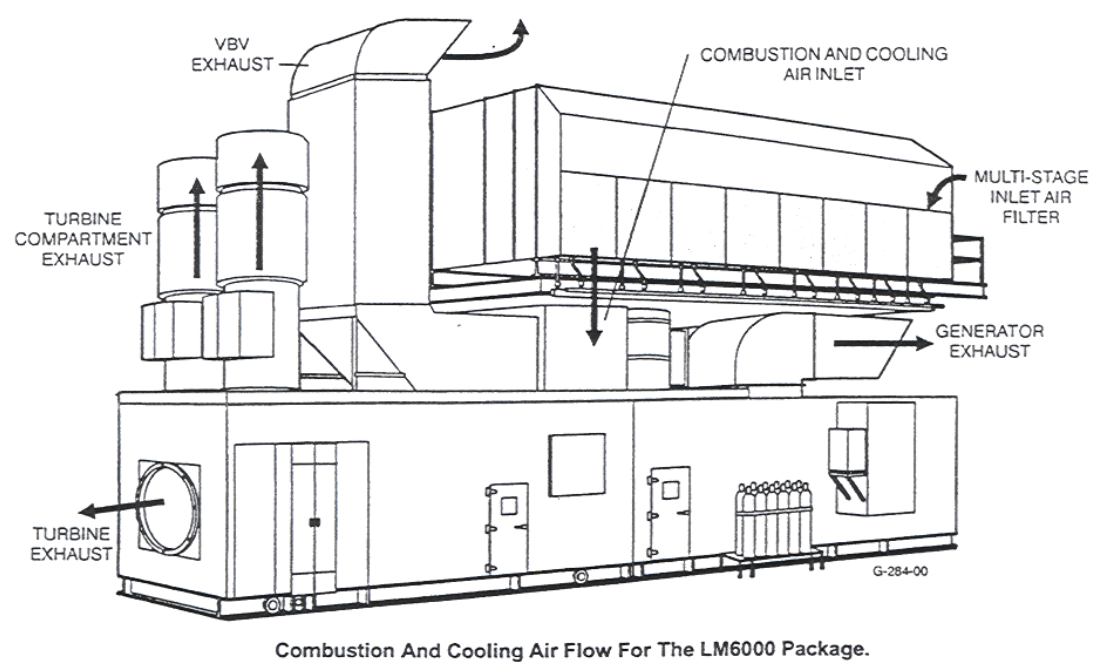

Figura 15 - Arranjo de montagem do sistema de admissão de ar sobre o grupo Turbogerador 


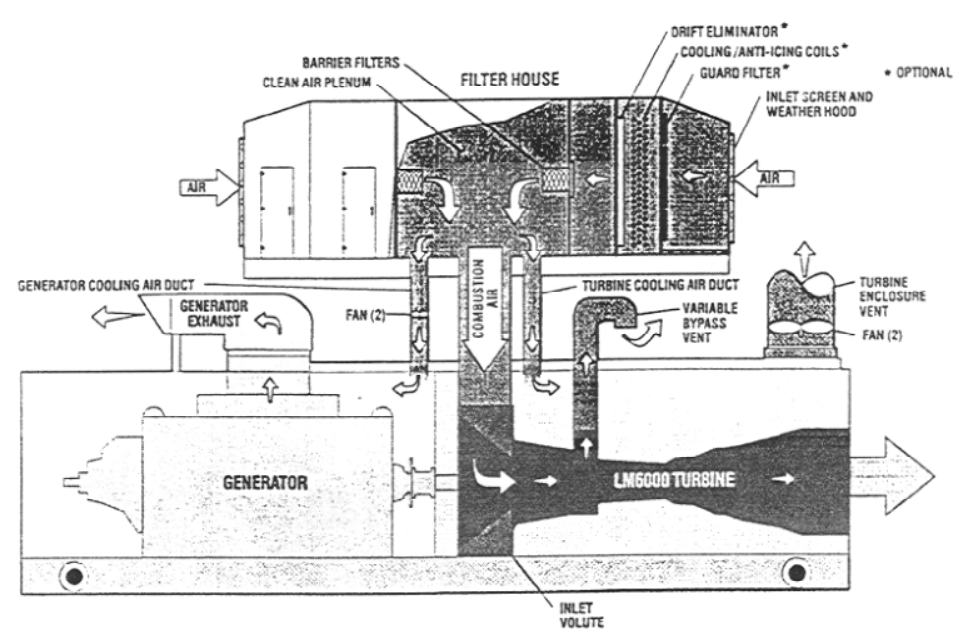

Figura 16 - Diagrama de fluxo de ar

Sistema de Resfriamento do Ar de Entrada nas Turbinas: para resfriar o ar de entrada nas turbinas, é empregada água captada no rio Macaé. Após a captação, as águas são clarificadas em uma estação de clarificação instalada próxima ao rio, sendo então utilizadas para make up da torre de resfriamento. Esta torre é parte integrante do Sistema de Água de Recirculação, composto de um circuito fechado formado por bombas de água de recirculação, trocadores de calor, tanque piezométrico/reposição de perdas; sistema de aditivação, tubulações, válvulas e acessórios, além da torre de resfriamento mecânico já mencionado;

Sistema de Injeção de Água nas Turbinas para Controle do NOx: para efeito de controlar a emissão de NOx, é empregada água captada no rio Macaé, que, para tanto, é também clarificada na estação de clarificação e posteriormente desmineralizada para injeção nos combustores das turbinas. O Sistema de Tratamento de Água é composto, na sua totalidade, por uma captação e transferência de água bruta, pré-tratamento da água bruta (clarificação), desmineralização e finalmente tratamento de seus efluentes;

Sistema de Ventilação: há um sistema de ventilação para o invólucro da turbina compreendendo dois ventiladores para o invólucro e um outro para o compartimento do óleo. 


\section{4 .4}

\section{Sistema e Equipamentos de Distribuição Elétrica da Usina}

Este sistema é composto pela subestação elevadora onde estão situados os transformadores. A subestação de manobra é do tipo convencional e alimenta os sistemas elétricos auxiliares, painéis, centros de controle, sistemas de segurança, de comunicação, de proteção, de medição e de iluminação. A subestação possui ainda um sistema de aterramento e para-raios; para sua proteção.

\section{4 .5}

\section{Sistemas Auxiliares da Usina}

Compreendem os sistemas de proteção contra incêndio e de comunicação descritos a seguir:

Sistema de Proteção Contra Incêndio: sistema completo de proteção contra incêndio composto de detectores óticos de chamas, detectores de hidrocarboneto, detectores térmicos, tubos, esguichos instalados em ambos os invólucros da turbina e do gerador. O sistema de proteção contra incêndio é composto de cilindros $\mathrm{CO}_{2}$ montados em um módulo separado.

Sistema de Comunicação: o sistema de comunicação da usina incluirá linhas telefônicas diretas.

Sistemas de Controle Digital e de Monitoramento: para controle do grupo turbogerador é empregado um sistema simples e confiável para efeito de entrada em carga automática, além de chaves de intertravamentos, de desligamento e alarmes. Este inclui: Um painel de controle; Controles, sensores e transmissores inteligentes na turbina e no gerador; Baterias de controle e carregadores; Painéis locais de medição. 


\subsection{6}

\section{Sistema de Abastecimento de Água}

O Sistema de abastecimento de água da UTE Macaé é implementado contemplando os seguintes processos: captação e transferência de água bruta, pré tratamento da água bruta (clarificação), desmineralização e tratamento de seus efluentes.

A água bruta a ser processada é disponibilizada no respectivo tanque de armazenamento através de um sistema de captação e transferência, dimensionado levando em consideração as demandas de água pré-tratada para o make-up da torre de resfriamento e suprimento dos consumos de água desmineralizada, bem como em função do lastro necessário para a rede de hidrantes do sistema antiincêndio e backup do sistema Mulsyfire.

O insumo básico para o processo de pré-tratamento é suprido através das bombas de transferência de água bruta, com linhas de aspiração conectadas ao respectivo tanque de armazenamento. As fases de pré-tratamento e desmineralização são realizadas conforme apresentado a seguir.

Através da clarificação, a água bruta aduzida pelas bombas de transferência alimenta o flocodecantador recebendo inicialmente injeções de soda para ajuste do $\mathrm{pH}$ ao nível ideal para o processo de floculação. Em seguida para promover o processo de flocodecantação é adicionado sulfato de alumínio como agente floculante. Finalmente a água, já clarificada pelo processo de flocodecantação recebe a adição de hipoclorito de sódio para desinfecção. A adição de produtos químicos é feita de forma controlada, de acordo com as condições apresentadas pela água bruta, de maneira que não superdosagem e, em especial, visando a que o residual de alumínio no efluente do flocodecantador seja nulo. O acúmulo de lama formado no flocodecantador é retirado automaticamente por descargas de fundo periódicas. A água processada no flocodecantador é submetida ao estágio de filtragem, seção final de pré- tratamento, sendo então disponibilizada no tanque reserva de água clarificada como insumo básico para as seguintes aplicações: 
- Make-up das perdas na torre de resfriamento do sistema de água de circulação;

- Processo de produção de água desmineralizada;

- Backup para o sistema mulsyfire;

- Água potável.

O efluente de fundo do flocodecantador é processado num sistema de filtragem/concentração de lama. Uma linha de overflow recupera, parcialmente, a fase líquida presente, canalizando-a para o tanque auxiliar de recuperação do efluente líquido de fundo do flocodecantador. Posteriormente ao estágio de concentração, a parcela de fundo do concentrador é processada por filtroprensagem, que propicia a recuperação da fase líquida e descarga da fase sólida para o depósito externo. Esta descarga consiste na produção de cerca de 3 metros cúbicos de resíduo sólido por dia.

Na desmineralização, o suprimento de água para esta fase de tratamento é realizado através bombas de desmineralização, com capacidade de reserva de 100\%, com aspirações conectadas ao tanque de água clarificada, com o processo desenvolvendo-se da seguinte forma:

a) Na primeira fase, durante a Permutação de cations, acontece a extração de CO2. O fluxo de descarga das bombas de desmineralização é dirigido por linhas de processo adequadas para um vaso que contém um leito de resina permutadora de ions positivos (trocador catiônico), com capacidade de reserva de $100 \%$, onde se processam as seguintes reações de troca.

O efluente do trocador catiônico, de natureza ácida, é conduzido por tubulações ebonitadas para as torres de desgaseificação convencionais, onde se processa a extração de CO2. Esta etapa é aplicável caso o teor de carbonatos normalmente presente na água in natura assim o justifique. Ao final desta fase a água descationizada é armazenada num tanque de passagem (tanque de água descationizada) no qual serão conectadas as tubulações de sucção das bombas auxiliares de desmineralização, que suprem as demais fases do processo de produção. 
b) Já na segunda fase, onde acontece a permutação de anions, o fluxo de descarga da bomba auxiliar de desmineralização é dirigido por tubulações de processo adequadas ao caráter ácido do efluente catiônico, para um vaso contendo um leito de resina permutadora de íons negativos (trocador aniônico), onde se processam reações de troca.

O efluente do trocador aniônico é, portanto, água desmineralizada que, por sua vez, é conduzida ao estágio final de polimento para garantir sua extrema pureza.

c) Na terceira Fase acontece o polimento final, onde é realizado mediante troca iônica e utilizando trocadores de leito misto, formados por mistura de resinas aniônicas, catiônicas e inerte, de densidade intermediária, que otimiza as separações de resinas para as operações de regenerações dos leitos. Neste estágio serão retidos os íons passantes pelas fase anteriores.

O efluente dos trocadores tipo leito misto é direcionado para o tanque de água desmineralizada. Este tanque terá capacidade de armazenamento no mínimo suficiente para 12 horas de operação na base de todas as turbinas na máxima taxa de consumo.

O ciclo de trabalho dos trocadores iônicos é supervisionado automaticamente e operações de reativação dos leitos de resinas são desenvolvidas ao ocorrerem saturações de sua capacidade de troca, condição esta que pode ser monitorada em função das seguintes variáveis:

- Monitoração do fluxo totalizado de água tratada, em nível compatível com as condições especificadas no projeto da planta de desmineralização.

- Elevação de pH no efluente, no caso dos trocadores do tipo catiônico;

- Elevação do valor da condutividade do efluente nos casos dos trocadores aniônicos e leitos mistos.

Nestes casos, monitores de valores limites inicializam as seqüências de shutdown dos trocadores exauridos e acionam os alarmes respectivos, notificando 
ao operador para que sejam tomadas as providencias necessárias às realizações das sequências de regenerações dos leitos exauridos. As regenerações se processam em operações similares àquelas do processo de produção.

Os efluentes químicos dos processos de regenerações das resinas iônicas, assim como todos os demais efluentes de processos de injeções químicas, por exemplo, oriundos de limpezas de tanques dosadores, são direcionados, por adequadas linhas de processo, para um tanque de tratamento de rejeitos químicos anteriormente ao despejo.

\subsection{7}

\section{Sistema de Drenagem}

O sistema consiste em canaletas periféricas ao longo de todo o perímetro da área da planta e descarrega num dreno natural existente nas proximidades, lembrando que somente para águas pluviais, e que todas as áreas passíveis de qualquer tipo de vazamento ou resíduos provenientes te lubrificação e limpeza eram providos de sistema de drenagem próprio.

\section{4 .8}

\section{Sistema de Tratamento Sanitário}

A usina é dotada de um sistema de tratamento sanitário dimensionado para cerca de 60 pessoas e operado seguindo os requisitos da legislação ambiental, em especial a NT-202 da FEEMA.

\section{4 .9}

\section{Sistema de Tratamento de Efluentes do Processo}

O projeto da usina contém bacias de neutralização, lagoas de retenção e separadores de óleo e água, torres de resfriamento de água, para tratar e controlar os efluentes a níveis adequados de descarga no corpo d’água. Os efluentes serão 
tratados de forma a atender os padrões legais vigentes considerando-se para tanto a Resolução CONAMA 20/86 Art. 21 e os padrões de lançamento estabelecidos pela NT-202 R10. Estima-se que o volume de efluente da usina será da ordem de $12 \mathrm{l} / \mathrm{s}$.

\section{4 .10}

\section{Sistema de Controle de Emissões Atmosféricas}

O sistema de controle de emissões previsto inclui um sistema de remoção de NOx por injeção de água que atua no combustor das turbinas. Além disso, o sistema será dotado de equipamentos portáteis do tipo LANCOM Premier ou similar para monitoramento de emissão nas chaminés de exaustão visando o controle das emissões quanto aos parâmetros O2, CO, NOx, temperatura e vazão. O equipamento portátil será do tipo aceito pelas normas americanas do EPA para conformidade com auditorias e testes das emissões.

O sistema de exaustão e o processo de redução de NOx serão projetados para atendimento aos padrões de emissão do Banco Mundial (Max. 60ppmv na fonte), assim como os padrões fixados pela legislação brasileira para concentração máxima de NOx ao nível do solo. Com base em estudos de dispersão realizados, estes padrões são atendidos para chaminés de altura igual a 20m ou mais.

\section{4 .11}

\section{Sistema de Controle de Ruídos}

Uma usina de ciclo simples compreende várias fontes de ruído. As mais significativas incluem a turbina de combustão, o gerador e os exaustores. O projeto levou em consideração as alternativas tecnológicas necessárias para garantir que aumento do nível de ruído de fundo nos limites da propriedade onde se instalou em total conformidade com a legislação brasileira e os padrões estabelecidos pelo Banco Mundial. 
Os ruídos decorrentes destes equipamentos são atenuados pela utilização de invólucros dotados de proteção acústica por meio de fibra de vidro e silenciadores nas entradas de ar. Os níveis de ruído esperado a 1 metro dos equipamentos não excedem $85 \mathrm{~dB}(\mathrm{~A})$.

\section{4 .12}

\section{Sistema de Coleta e Disposição Final de Resíduos Sólidos}

Os resíduos sólidos do processo de filtroprensagem, realizado na fase final do tratamento de água, são armazenados provisoriamente, em condições compatíveis com os resíduos de Classe II, e encaminhados para disposição final por empresa especializada e licenciada pela antiga FEEMA, hoje INEA. A geração de tais resíduos é estimada em cerca de três metros cúbicos por dia.

Os resíduos sólidos domésticos produzidos nas dependências de administração e refeitório da usina são adequadamente acondicionados e removidos para o aterro sanitário da cidade de Macaé. 


\section{6 \\ GESTÃO AMBIENTAL DO EMPREENDIMENTO}

\section{1 \\ Introdução}

Para implementação das estratégias o SGA, este foi estruturado em programas orientados pelos objetivos de: mitigação, controle ambiental planejados para o empreendimento, com a necessidade do cumprimento dos mais rigorosos padrões brasileiros e internacionais, fez com que a empresa responsável pelo empreendimento se estruturasse, e colocasse em prática um sistema de gestão ambiental EMMP (Enviromental Management Monitoring Program) que utiliza o formato ISO 14001 como base, tudo isso com o objetivo de ter um excelente desempenho ambiental, demonstrando a responsabilidade ambiental do empreendedor na implantação e operação do projeto.

O mais interessante em todo processo, não foi o fato de se querer uma mera certificação, fato identificado durante as pesquisas sobre o assunto em referência, e que acontece em algumas empresas, que só conseguem enxergar a necessidade de envolvimento e investimento nos aspectos de caráter ambiental e de sustentabilidade, com intuito de cumprir uma formalidade quando de uma solicitação de um cliente e/ou vantagens subjetivas, como exemplo, de aparecerem em indicadores de sustentabilidade, na busca de um marketing faz de conta.

O compromisso foi selado por todos os níveis da corporação, isto é, não funciona e nunca funcionará um sistema de gestão sem comprometimento de todas as áreas e que permeie em todos os níveis de uma corporação. Cada um tem e terá uma função clara e objetiva para implantação, desenvolvimento e melhoria contínua de um sistema de gestão factível e bem estabelecido. 


\section{2}

\section{Estrutura do sistema de gestão ambiental do empreendimento}

O Sistema de Gestão Ambiental EMMP (Environmental Management Monitoring Program), foi baseado na norma NBR ISO 14001, que é baseada em normas internacionais de gestão ambiental.

Consistente com tais normas, o sistema proposto neste documento inclui a definição de uma estrutura organizacional, responsabilidades, métodos, procedimentos, processos e recursos para implementação da gestão ambiental, além de registrar as metas da política ambiental do empreendedor no que diz respeito ao desempenho ambiental do empreendimento.

No que concerne a organização e responsabilidades para implementação do SGA, todos os programas ambientais especificados para a Usina Térmica Macaé foram executados diretamente pelo empreendedor ou por empresas contratadas sob sua responsabilidade.

A finalidade de organizar os programas ambientais sob uma estrutura sistêmica é a de permitir o gerenciamento integrado da execução desses programas, administrando permanentemente suas interfaces e verificando, ao longo de todo o processo, o atendimento aos prazos, às abordagens metodológicas normatizadas e/ou consensadas com o Órgão Ambiental, bem como às exigências ambientais aplicáveis.

É responsabilidade do sistema proposto, o acompanhamento e avaliação permanente dos efeitos sobre o meio ambiente, decorrentes das atividades, produtos e serviços do empreendimento, ao longo de todo o ciclo de instalação e operação, bem como o registro e documentação deste processo.

Para a implementação de um adequado gerenciamento dos problemas que afetam o meio ambiente na implantação e operação de um empreendimento, como a Usina Térmica Macaé, foi necessária uma estrutura organizacional que refletisse o comprometimento da alta gerência e das lideranças do empreendimento com a garantia do desempenho ambiental compromissado na fase de planejamento e licenciamento do mesmo. 
Para tanto, foi designada uma Unidade de Supervisão Ambiental, com prerrogativas de intervir nos processos de implantação e operação da Usina, a qual era responsável pela condução integral do SGA, possuindo uma atribuição formal de competência na estrutura organizacional responsável pelo empreendimento.

O Supervisor Ambiental atuava tecnicamente, em ações internas à empresa, bem como nas relações de gestão técnica com terceiros, encarregados de tarefas específicas dos programas componentes do SGA. Respondia ainda pelas interfaces com o Órgão Ambiental no que concerne à demonstração formal e/ou mandatórias dos resultados obtidos pelos programas de gestão ambiental do empreendimento.

No tocante às relações ambientais externas, que envolvem contatos com a comunidade ou com instituições não incluídas na esfera dos órgãos públicos de gestão ambiental, a unidade de Supervisão Ambiental do empreendimento atuava com apoio de técnicos especializados da área de relações púbicas da empresa ou de especialistas externos, envolvidos no Programa de Comunicação Social.

Todos os programas ambientais propostos neste foram vinculados ao Sistema de Gestão Ambiental, devendo os responsáveis por sua execução direta reportar-se à Unidade Supervisão Ambiental durante todo o desenvolvimento de suas atividades.

A Unidade de Supervisão Ambiental contava ainda com um profissional de Saúde Ocupacional, Segurança e Meio Ambiente - SSMA, que coordenava a execução das atividades internas ao empreendimento nesta área, fazendo cumprir as metas e os padrões operacionais determinados pela política de SSMA do empreendimento, verificando, registrando e reportando seu cumprimento.

Atribuições da unidade de Supervisão Ambiental:

- proporcionar aos diversos setores envolvidos a informação necessária para a operacionalização do gerenciamento ambiental;

- organizar a gestão ambiental, com o envolvimento destes setores, através da CIPA/CIMA; 
- supervisionar o estabelecimento das metas a serem mantidas/alcançadas em cada setor da organização, com base nas normas e padrões oficiais e corporativos;

- gerar normas e procedimentos internos, na forma de manuais, avisos e fichas orientativas;

- supervisionar o monitoramento de emissões e efluentes, executado nos setores específicos, visando ao controle das operações, e registrando os resultados obtidos;

- executar o monitoramento dos parâmetros de qualidade ambiental sob influência do empreendimento, conforme determinação do Órgão Ambiental, registrando e avaliando permanentemente os resultados;

- supervisionar ações conduzidas no contexto de cada um dos diversos programas ambientais propostos;

- fornecer subsídios à alta gerência da empresa para reavaliar o SGA, com base nos resultados do monitoramento e de auditorias ambientais realizadas, quando se fizer necessário.

Para verificar o funcionamento do Sistema de Gestão Ambiental foram realizadas auditorias ambientais internas, fundamentais para a manutenção dos padrões de qualidade ambiental e verificação da eficácia do sistema.

Os resultados do monitoramento de parâmetros gerados nos programas ambientais são registrados em banco de dados, visando ao estabelecimento de um sistema dinâmico de avaliação e ajustamento de desempenho das diversas interfaces ambientais do empreendimento.

Para tanto são mantidos paralelamente e nas mesmas condições, bancos de dados sobre:

- registro de acidentes e mau funcionamento, incluindo análise das causas e consequências; 
- documentação referente a fornecedores e empreiteiros, com insumos utilizados, registro de eventos, etc.

- documentação referente a insumos, com indicação de forma e local de estocagem e utilização, características físico-químicas, recomendações de estoque, manuseio e transporte, procedimento em caso de acidentes e emergências, efeitos sobre a saúde, relatório de eventos ocorridos no âmbito da UTE, etc.

As estratégias que foram implementadas pelo empreendedor com vistas a garantir o adequado desempenho ambiental do empreendimento, bem como daquelas voltadas a controlar a eficácia dos procedimentos, dispositivos e tecnologias adotados.

O conjunto de estratégias que integravam o Sistema de Gestão Ambiental - SGA :

- Estratégias de Mitigação;

- Estratégias de Monitoramento e Controle;

- Estratégias de Compensação Ambiental

Como demonstradas na figura à seguir: 


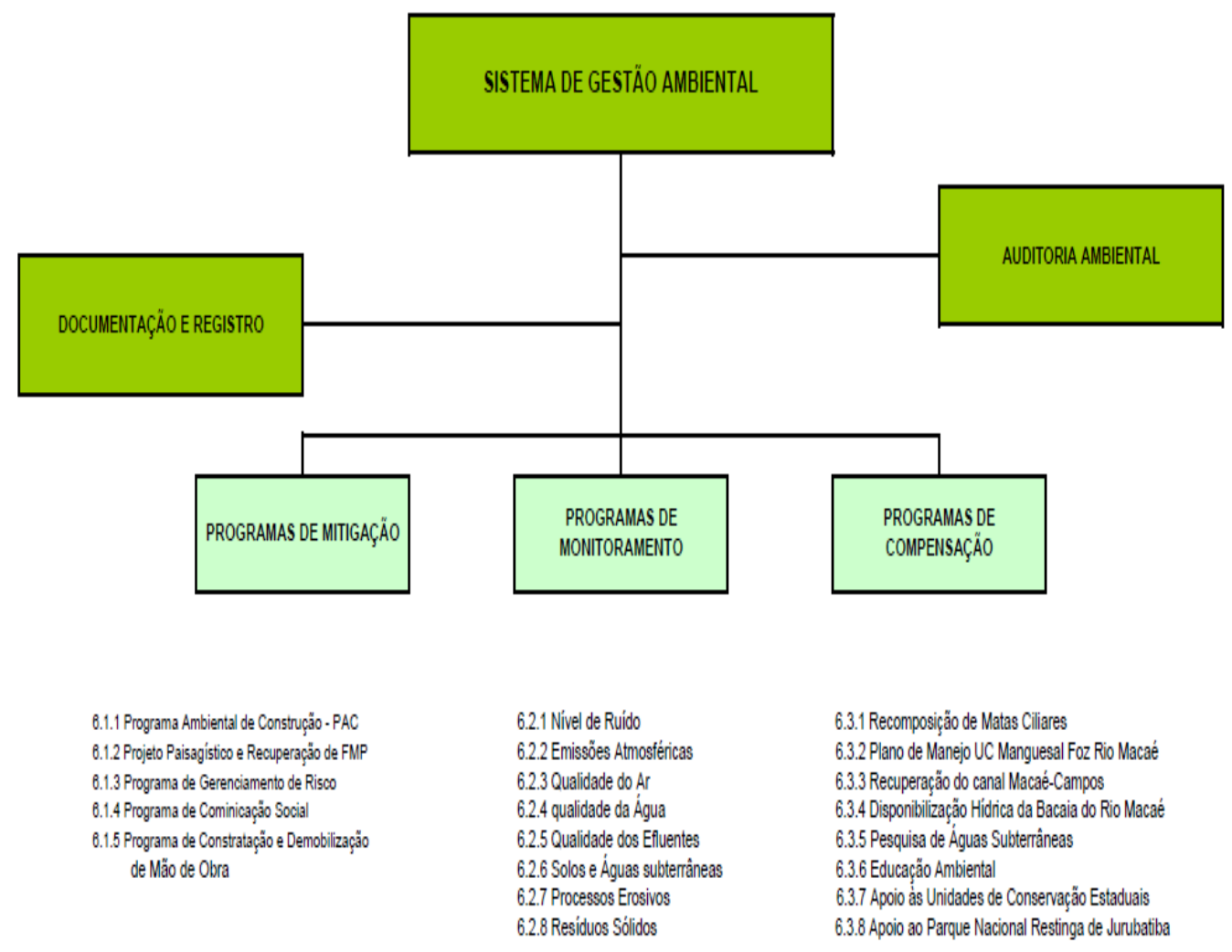

Figura 17 - Estrutura do Sistema de Gestão Ambiental do Empreendimento

\section{3}

\section{Programas de Mitigação}

\subsection{1}

Programa Ambiental de Construção - PAC

Dentro do programa ambiental de construção, foram determinadas algumas das principais áreas de impacto à seguir:

Qualidade do Ar, o impacto da qualidade do ar durante a construção se limitou a emissões de escapamentos de veículos / equipamentos e emissões de poeira fugitiva de operações de terraplanagem, manuseio de materiais, etc.

Drenagem de água de superfície e proteção da qualidade da água, o controle de drenagem de água de superfície do local, durante a construção, o projeto e instalação de dispositivos de drenagem como lagoas de contenção de águas de enxurrada e rampas/canaletas, estabilização de áreas afetadas (taludes e 
áreas de bota-fora), separadores de óleo/água para águas pluviais potencialmente contaminados e implementação de medidas de controle de erosão do local na sua amplitude maior.

Ruído e Vibração, os impactos de ruídos gerados na construção e de vibrações, sobre receptores críticos fora do local deveriam ser mínimos devido à distância relativa do local do projeto e à natureza temporária típica da construção geradora de ruído.

Proteção das Águas Subterrâneas e dos Solos, as atividades de construção têm o potencial de impactar a topografia de superfície do solo, a composição do solo e as taxas de infiltração de água através da compactação, remoção da camada superior do solo, e redistribuição temporária e permanente de solos durante nivelamento e escavação para fundações.

Fauna e Flora, as atividades de construção no local de projeto não impactaram significativamente áreas designadas para preservação da natureza.

Gestão de Resíduos, vários tipos de resíduos foram produzidos durante a construção no local. As instalações externas contratadas para reciclar, tratar, ou dispor resíduos gerados durante construção estarão sujeitas a uma inspeção précontrato e a inspeções periódicas durante o período de construção.

Transporte, as questões de transporte durante a construção estão relacionadas com a movimentação segura e eficiente de pessoal e materiais em todas as estradas, além da minimização de atrasos e outras perturbações dos padrões de tráfego locais.

Postura Ambiental dos Trabalhadores, foi requerido dos trabalhadores o cumprimento das normas e procedimentos de saúde e de diminuição de resíduos, nas frentes de trabalho, canteiros, estradas de acesso.

Não foi permitida em nenhuma hipótese a caça, comercialização, guarda ou maus tratos a qualquer tipo de animal silvestre. 


\subsection{2 \\ Projeto paisagístico e de recomposição da faixa marginal de proteção}

Projeto que foi realizado durante a fase de implantação do empreendimento, este projeto não se fixou unicamente ao beneficiamento paisagístico das áreas de circulação internas e externas à UTE, contemplou também a implantação de faixas de vegetação arbórea junto às cercas divisórias, a formação de bosques arbóreos nas glebas situadas no entorno das instalações, em glebas planas e onduladas, assim como o adensamento da vegetação ciliar que ocorre em parte da faixa marginal do antigo leito do rio Macaé.

\subsection{3}

\section{Programa de gerenciamento de riscos}

O Programa de Gerenciamento de Riscos foi estabelecido com o objetivo da manutenção da operação da UTE Macaé dentro de limites de segurança aceitáveis pela sociedade. O programa corresponde a um conjunto de recomendações de segurança, que visam a mitigação ou minimização dos riscos identificados pelo estudo de Análise de Risco da UTE Macaé.

O programa contempla ainda o planejamento de implantação das ações, responsabilidades e cronograma. A implementação das medidas mitigadoras recomendadas pelo estudo só têm efeito quando há um programa completo e contínuo de inspeção, de manutenção e de treinamento de operadores.

O programa de gerenciamento de riscos apresentou diretrizes gerais e específicas para os sistemas nas diversas fases, conforme descrito à seguir:

Durante a fase de construção e montagem algumas ações específicas foram tomadas:

- Adoção de medidas para a verificação dos procedimentos de armazenamento e movimentação de materiais e equipamentos; 
- Adoção de check-list para a certificação da qualidade na fabricação e recebimento de materiais;

- Checagem dos procedimentos e materiais durante a realização de soldagens;

- Contatar os Órgãos envolvidos com as atividades de resposta a emergências no Município de Macaé,. Defesa Civil, Corpo de Bombeiros, Secretaria de Meio Ambiente, etc, apresentando o plano de construção do empreendimento, e traçando estratégias de ação para o caso de ocorrência de algum acidente de obra.

Durante a fase de operação algumas ações específicas foram tomadas:

- Treinamento da equipe de operação para as situações de emergência;

- Sempre que houver mudanças, manter atualizados os operadores do sistema com relação às rotinas de operação, de modo a evitar que sejam tomadas decisões erradas;

- Manter atualizado o Plano de Atendimento a Emergências, contemplando, quando necessária a atuação conjunta com Corpo de Bombeiros, Defesa Civil, etc.;

- Manutenção da equipe de serviço preparada para situações emergenciais, com conhecimento adequado, rápido e eficiente;

- Implantar sinalização de segurança (com o número do telefone para situações de emergência).

O risco de incêndios, explosões, vazamentos e outros acidentes capazes de originar uma situação de emergência foram considerados, apesar das medidas de segurança existentes. Por esse motivo e em atendimento a legislação em vigência, foi elaborado o PAE (Plano de Ações de Emergência), com o objetivo de organizar e treinar equipes e funcionários para que, numa situação de emergência, estejam aptos a combater o evento. 
O Plano de Ações de Emergência foi desenvolvido a partir das informações resultantes do Estudo de Análise de Risco da UTE Macaé Merchant. O PAE contemplou ações específicas para o controle de emergências potencialmente geradas pelos cenários acidentais previstos pelo estudo de risco.

Seguem algumas diretrizes e aspectos levados em consideração no PAE:

- estrutura organizacional, contemplando atribuições e responsabilidades da equipe e da organização de combate da emergência;

- elaboração dos procedimentos de emergência para os seguintes as situações de risco:

- combate a vazamentos;

- $\quad$ incêndio e/ou explosão;

- riscos da natureza;

- emergências fora da planta;

- riscos à comunidade.

- descrição e quantificação dos equipamentos de combate as emergências e dos alarmes;

- relação e localização dos EPI’s, equipamentos e combate a incêndio além daqueles para contenção, abatimento e recolhimento de produtos;

- sistemas de comunicação, sinalização e alarmes;

- sistemas alternativos de geração e distribuição de energia;

- relação de recursos de outras entidades que poderão prestar auxílio;

- rotinas de combate específicas para cada um dos possíveis acidentes previstos;

- procedimentos de abandono 


\section{3 .4}

\section{Programa de comunicação social}

Este programa foi iniciado na fase de elaboração do EIA/RIMA da UTE Macaé, justificou-se naquela etapa, pela necessidade de levar ao conhecimento da população local as perspectivas de implantação de um novo empreendimento na região. O objetivo do programa na sua primeira fase, era o de prover a população de informações que lhe permitissem estabelecer um posicionamento em relação ao empreendimento, assim como em relação aos potenciais impactos positivos e negativos a ele associados.

Visava-se com isto ao conhecimento das perspectivas locais em relação ao empreendimento e seus impactos, importante fator de orientação ao planejamento ambiental do mesmo, de forma a garantir sua adequada inserção local.

O Programa de Comunicação Social passa a justificar-se pela necessidade de manter o canal de comunicação aberto com a população, tendo em vista os seguintes objetivos:

- Dar a conhecer à população o teor e os resultados esperados das medidas de mitigação de impactos e compensação ambiental a serem adotadas pela empreendedora nas fases de implantação e operação do empreendimento;

- Divulgar informações relativas ao acompanhamento da implementação e ao monitoramento dos resultados de tais medidas, bem como conhecer a opinião da população quanto a eficácia das mesmas;

- Manter um canal de comunicação aberto a manifestações espontâneas da comunidade;

- Ampliar a longo prazo, as perspectivas de inserção local do empreendimento, através de oportunidades identificadas ou criadas no processo de comunicação com a comunidade local. 


\section{3 .5}

\section{Programa de contratação e desmobilização de mão de obra}

A usina foi construída em 18 meses. A mão-de-obra utilizada durante a construção do empreendimento foi de aproximadamente 1000 empregados no período de pico.

Para a operação são necessários 60 funcionários, operando em 3 turnos.

Considerado um impacto positivo, a geração de empregos decorrentes da implantação da UTE Macaé foi feita de forma a aliviar pressões provenientes da eventual atração de migrantes em busca de oportunidades de emprego.

Para minimizar os impactos negativos decorrentes da contratação e desmobilização dos trabalhadores, e potencializar os benefícios destes empregos, mesmo que temporários, para a região de Macaé, as seguintes medidas foram adotadas:

- priorizar as contratações locais, considerando a oferta de mão-deobra disponível;

- garantir a possibilidade de treinamento caso o candidato possua perfil potencial para o cargo a ser ocupado e resida na região

\section{4}

\section{Programas de Monitoramento}

\subsection{1}

\section{Emissões e nível de ruído}

Durante a implantação e operação da UTE Macaé Merchant diversos equipamentos emitirão ruídos que alterarão o nível de ruídos existentes anteriormente na área de influência direta do empreendimento, alterando a qualidade ambiental. 
No que se refere às emissões de ruído, as mesmas devem atender a legislação estadual e federal que estabelece que os equipamentos podem emitir no máximo $85 \mathrm{~dB}(\mathrm{~A})$ a 1 metro da fonte emissora.

Com relação ao nível de ruído no ambiente, a Norma NBR 10151 (citada na Resolução CONAMA 01/90), fixa os níveis de ruído de acordo com o uso e ocupação do solo, e especifica métodos para a medição de ruídos, envolvendo medições na escala de compensação A, em decibéis, comumente denominado de $\mathrm{dB}(\mathrm{A})$.

De acordo com esta norma, os níveis de ruído no ambiente devem estar abaixo de $40 \mathrm{~dB}(\mathrm{~A})$ em áreas rurais durante o período diurno (06:00 às 20:00h) e inferior a $35 \mathrm{~dB}(\mathrm{~A})$ durante o período noturno (20:00 às 06:00 h).

A Portaria GM/nº 092, de 19/06/1980 estabelece ainda (parágrafo II) que são prejudiciais à saúde, à segurança e ao sossego público, os sons e ruídos que:

- atinjam, no ambiente exterior do recinto em que têm origem, nível de som de mais de 10 (dez) decibéis - dB (A), acima do ruído de fundo existente no local de tráfego;

- independente do ruído de fundo, atinjam no ambiente exterior do recinto em que têm origem, nível de som de mais de 70 (setenta) decibéis - $d B(A)$, durante o dia, e 60 (sessenta) decibéis - $d B(A)$, durante a noite;

- alcancem no interior do recinto em que são produzidos níveis superiores aos considerados aceitáveis pela Norma NB-95, da Associação Brasileira de Normas Técnicas - ABNT, ou das que lhe sucederem.

Mesmo considerando que não existem atualmente no entorno do empreendimento áreas urbanas, apenas habitações de fazenda, o nível de ruídos pode perturbar o bem estar de pessoas que residam ou trabalhem neste local, sendo importante efetuar o monitoramento do nível de ruídos decorrente das ações do empreendimento. 
Deste modo, o monitoramento dos níveis de ruído visa assegurar que as emissões de ruído estarão em concordância com a legislação estadual e federal, isto é, abaixo de $85 \mathrm{~dB}(\mathrm{~A})$ à 1 metro das fontes de ruído e assegurar que o nível de ruído nos limites da usina estará de acordo com a regulamentação federal, e/ou internacional (aquela que for mais restritiva),garantindo o conforto, a saúde e o bem estar da população externa à usina.

As medições são efetuadas com medidor de nível sonoro com capacidade para integrar as medidas e calcular automaticamente o nível sonoro equivalente.

Em ambientes externos as medições serão efetuadas a 1,2 m acima do nível do solo e a 1,5 m de distância das fontes (ou paredes dos edifícios em caso de fontes internas).

Nos ambientes internos as medições serão efetuadas a distância mínima de $1 \mathrm{~m}$ das paredes, $1,2 \mathrm{~m}$ acima do piso e a 1,5 $\mathrm{m}$ das janelas. Para evitar distorções, as edições internas serão as médias de 3 medições distintas a 0,5 m de distância uma da outra.

As medições foram realizadas nos períodos diurno e noturno, em dias úteis e fins de semana, durante 10 minutos cada. Essas medições são efetuadas uma vez por ano.

Os locais de medição incluíram outro empreendimento no limítrofe da propriedade, assim como a BR-101. Além destes locais, foram realizadas medições nas imediações das fontes de ruído.

Relatórios anuais são apresentados ao órgão ambiental, contendo o resultado das medições e as seguintes informações adicionais:

- $\quad$ Nível sonoro medido em dB(A);

- Condição de operação da fonte de ruído e características climáticas reinantes durante as medições (temperatura, direção e velocidade dos ventos);

- Hora de ocorrência do ruído e das medições; 
- Nível sonoro corrigido;

- Nível de ruído de fundo medido;

- Croquis com a localização dos pontos de medição.

Os ruídos medidos são comparados com os limites estabelecidos na legislação, tanto para emissões de ruído quanto para níveis de ruído no ambiente, de acordo com o uso do solo na região.

\subsection{2}

\section{Emissões Atmosféricas}

A utilização de gás natural para a geração de eletricidade produz emissões atmosféricas. A emissão de determinados poluentes para o ar tem limites previstos na legislação brasileira que devem ser obedecidos, de modo a evitar a ocorrência de impactos ambientais indesejáveis.

O programa de monitoramento de emissões atmosféricas estabelecido, visa verificar se as concentrações emitidas pelas chaminés, durante a operação da planta, estão de acordo com os critérios e limites adotados nos estudos ambientais realizados. Deste modo, o monitoramento das emissões atmosféricas se constitui em fonte de informação do desempenho ambiental da UTE Macaé.

O monitoramento das emissões atmosféricas visa também atender ao PROCON AR- Programa de Autocontrole de Emissões para a Atmosfera, estabelecido pela DZ 545 de 07/08/86, que é parte integrante do Sistema de Licenciamento de Atividades Poluidoras - SLAP, e também atender à restrição No. 5.20 da Licença Prévia 013/2001 concedida para a UTE Macaé.

Para monitoramento das emissões são usados os equipamentos do tipo CEMS - Continous Emission Monitoring System. A função principal do sistema CEMS na chaminé, é medir a velocidade de saída dos gases, a temperatura e a pressão de saída dos gases, a vazão dos gases para manter as condições de velocidades isocinéticas estabilizadas. Durante os testes isocinéticos, parâmetros como a velocidade e a temperatura de saída dos gases, são continuamente 
monitorados e a taxa de amostragem dos poluentes é periodicamente ajustada de tal modo que as velocidades de saída dos gases e a isocinética se mantenham aproximadamente iguais.

Todos os testes de operacionalidade do sistema seguem o que determina o 5 Test Methods USEPA, o qual estabelece o protocolo geral para coleta automática de dados de tal modo que a amostra final seja o mais representativa possível do que estará sendo emitido para atmosfera. Os gases que são amostrados são: o O2, o $\mathrm{NO}_{\mathrm{x}}$ e o $\mathrm{CO}$.

O Sistema de Monitoramento Contínuo de Emissões de Chaminé é composto dos seguintes equipamentos:

- $\quad$ Medidores de Gases

- Medidores de particulado

- Calibradores automáticos dos aparelhos

- Sistema automático de limpeza de filtros;

- Condicionadores de amostra de gases;

- Saídas digitais e analógicas para salas de controle do queimador de gases

- Sistema de Alarme ajustáveis;

- Coleta e armazenagem automática de dados;

- Sistema de alarme geral dos dados.

O conjunto acima permite um monitoramento contínuo, coleta de informações e controle em tempo real de todo o processo de queima, acusando qualquer anomalia no sistema de amostragem, tais como: mudança no perfil do combustível ou queima; entradas de ar falso, defeitos ou desajustes da combustão, geração de relatórios e planilhas na sala de controle, sem a interferência e ou erros de interpretação dos operadores. 
Foram projetadas 20 chaminés para a UTE Macaé. O processo de combustão do gás natural vai gerar a emissão dos mesmos poluentes nas 20 chaminés. Essas chaminés foram projetadas com as mesmas características de altura e diâmetro. Nas turbinas onde elas estão acopladas são emitidas as mesmas taxas de emissões de gases simultaneamente.

Entende-se, portanto, que não há diferenciação significativa entre os processos químicos na geração e emissão de poluentes, visto que a matéria prima de combustão é a mesma. Além disso, as chaminés possuem os mesmos parâmetros de projeto nas fontes, isto é, velocidade de saída dos gases, vazões dos gases, temperatura de saída dos gases, etc.

Tendo em vista tais fatores o monitoramento contínuo será realizado em uma chaminé a cada grupo de quatro. Assim, em cada grupo de quatro será instalado um Sistema de Monitoramento Contínuo de Emissões - CEMS. As demais chaminés serão amostradas periodicamente com amostradores portáteis.

Conforme solicitado pelo INEA, na Licença Prévia No. 013/2001 para a UTE Macaé (item 5.20), as informações geradas serão tratadas e disponibilizadas em tempo real para a Central de Dados de Qualidade do Ar do INEA.

Cada CEMS foi instalado no respectivo grupo de chaminés durante a fase de montagem das mesmas, entrando em teste e operação juntamente com e entrada em operação do respectivo grupo.

O programa de amostragem proposto é apresentado a seguir, e terá a seguinte rotina: A primeira amostragem de cada grupo de chaminés será realizada dois meses após o início de operação de cada grupo sendo seguida por uma segunda campanha, três meses após a primeira, uma terceira é realizada seis meses após a segunda e depois as campanhas foram realizadas a cada seis meses, encerrando-se após vinte e quatro meses de monitoramento, onde a reavaliação foi feita em conjunto com o INEA.

Ao final de cada amostragem foi expedido um relatório técnico comparativo entre as medições do sistema CEMS e a amostragem manual, com 
uma avaliação técnica sobre a coerência dos resultados, que após a análise final será encaminhado para o órgão ambiental.

\subsection{3}

\section{Qualidade do ar}

Com o intuito de estabelecer estratégias para o controle, preservação e recuperação da qualidade do ar, válidas para todo o território nacional, conforme previsto na Lei $\mathrm{n}^{0}$ 6.938/81, foi instituído o PRONAR Programa Nacional de Controle da Qualidade do Ar pela Resolução CONAMA n ${ }^{\circ}$ 005/89, dando definições e diretrizes para prevenção e gerenciamento.

Posteriormente, padrões de qualidade do ar foram estabelecidos pela Resolução CONAMA no.003/90 para partículas totais em suspensão, fumaça, partículas inaláveis, dióxido de enxofre, monóxido de carbono, ozônio e dióxido de nitrogênio.

A geração termelétrica a gás natural gera emissões de poluentes que são dispersados no entorno da usina, como foi demonstrado nos Estudos de Dispersão Atmosférica. Esses estudos se basearam em modelagem matemática, considerando entre outras informações, topografia local e dados climatológicos de um ano selecionado (Estação Meteorológica do Aeroporto de Macaé, 1995).

Para verificar a qualidade do ar local decorrente da operação da UTE Macaé é proposto o monitoramento da qualidade do ar no entorno do empreendimento.

Os principais objetivos do monitoramento da qualidade do ar podem ser assim definidos:

- Avaliar a qualidade do ar à luz de limites estabelecidos para proteger a saúde e o bem estar das pessoas;

- Acompanhar as tendências e mudanças na qualidade do ar devidas às alterações nas emissões dos poluentes de uma região por operação do empreendimento. 
A Resolução do CONAMA 03/90, de 28 de junho de 1990, definiu os padrões de qualidade do ar como sendo as concentrações de poluentes atmosféricos que, uma vez ultrapassadas, poderão afetar a saúde, a segurança e o bem estar da população, bem como ocasionar danos à flora e à fauna, aos materiais e ao meio ambiente em geral. Foram definidos padrões primários e secundários para partículas totais em suspensão, SO2, CO, O3, fumaça, partículas inaláveis e NO2.

Os parâmetros de qualidade do ar que são monitorados regularmente, são aqueles que apresentam relação direta com as principais emissões atmosféricas da UTE Macaé, ou seja: óxidos de nitrogênio (NOx, NO, NO2) O3, THC e CO.

Para a execução deste monitoramento foi adquirida uma estação telemétrica, que realizará amostragem e análise contínua dos parâmetros acima mencionados. Os resultados são continuamente transmitidos tanto para o empreendedor quanto para o órgão ambiental, INEA, online, onde são armazenados.

Além dos parâmetros de qualidade do ar, a estação também mede os seguintes parâmetros meteorológicos:

- Velocidade do vento;

- Direção do vento;

- Radiação solar ultravioleta;

- Temperatura e umidade relativa;

- Precipitação pluviométrica;

- Pressão atmosférica.

A região onde foi instalada a Usina Termoelétrica Macaé, um distrito rural distante 12,5 km, em linha reta, do centro urbano de Macaé. O local se caracteriza como rural, uma vez que possui uma ocupação populacional pequena e esparsa. De acordo com a USEPA (1987) uma região é considerada como urbana ou rural dependendo do total de habitantes por quilômetro quadrado, $\mathrm{p}$, da seguinte forma: 
- Região urbana: se a população p> 750 pessoas/km2,

- Região rural: se a população $\mathrm{p}<750$ pessoas/km2.

O terreno no entorno da área de influência do empreendimento é composto de morros suaves de baixa altitude e o setor Norte Noroeste do empreendimento é quase plano, apresentando solo do tipo várzea. O local do empreendimento, é caracterizado por boa taxa de ventilação, em posição elevada em relação ao entorno e dotada de boas condições de dispersão atmosférica. A ocupação do solo mais próxima é a Fazenda Severina (a SE da UTE), distante 1,5km e a Fazenda das Pedrinhas a 5,5 km e a (SW), localizadas de forma esparsas distantes uma da outra.

A opção de instalação da estação na Fazenda Severina que está a Sulsudeste da UTE distante 1,5 km, levou em consideração os seguintes fatores:

- Disponibilidade de energia elétrica;

- Área que não cause desconforto à população local;

- Área segura para a permanência dos equipamentos por longos períodos;

- Inexistência de fontes pontuais de poluição atmosférica como estradas não pavimentadas, obras, etc.;

- Acesso adequado para instalação e manutenção dos equipamentos.

A Estação Automática de Medição da Qualidade do Ar, realiza medição contínua de poluentes convencionais, não convencionais e de parâmetros meteorológicos na área de influência da Usina Termelétrica Macaé.

A estação é composta de software/hardware que realiza o gerenciamento dos dados, sendo composta de uma Estação Fixa e uma Central de Controle.

O conjunto de dados coletados na estação é transmitido, via linhas telefônicas (discadas) a computadores instalados em uma Central de Gerenciamento do Sistema, localizada nas dependências da UTE. Foram 
instalados dois terminais na central, que retransmitirão os dados, após um prétratamento, para os escritórios da EL-PASO e para o INEA.

\subsection{4}

\section{Qualidade da água no rio Macaé}

Embora não se esperasse alteração na qualidade da água do Rio Macaé em decorrência da operação da Usina Termelétrica Macaé, dada a importância deste curso d’água para o abastecimento púbico da região, foi efetuado um monitoramento da qualidade da água deste rio antes do início das obras da UTE Macaé, durante sua construção e durante sua operação.

O Programa de Monitoramento de Qualidade de Água justificou-se e se justifica pela necessidade de acompanhar a adequação dos efluentes aos padrões legais vigentes, através da verificação de seu desempenho em termos de alterações da qualidade do corpo hídrico na zona de lançamento dos mesmos. Este programa gerou também subsídios para o sistema regional de gestão ambiental, associado à bacia do rio Macaé.

Durante a campanha Inicial, o monitoramento foi feito em 2 pontos, um localizado $100 \mathrm{~m}$ a montante do local de descarga dos efluentes industriais (que será a montante do local de captação), e outro a 100 m a jusante do local de descarga do sistema. Tanto o lançamento quanto a captação estão localizados a montante da ponte da rodovia BR-101 que cruza o rio Macaé, e a montante também do sistema previsto para a UTE vizinha.

Foram realizadas duas coletas, uma em período de estiagem e outra em período de cheia. Foram determinados parâmetros de qualidade e realizadas medições de vazões nas duas estações de monitoramento propostas, de modo a determinar também a vazão do rio Macaé.

Inicialmente os seguintes parâmetros foram determinados nas estações de amostragem no rio Macaé: turbidez, cor, $\mathrm{pH}$, temperatura, condutividade elétrica, resíduos filtráveis totais, resíduos não filtráveis, oxigênio dissolvido, DBO, DQO, carbonato, cloreto, sulfato, nitrato, amônia, nitrogênio Kjeldahl, sílica, fosfato 
total, cálcio, magnésio, sódio, potássio, chumbo, cianeto, cobre, mercúrio, fenóis, óleos e graxas e coliformes fecais. A listagem acima está baseada nos parâmetros anteriormente analisados pelo órgão ambiental na região, com a adição de parâmetros relevantes para o controle operacional do tratamento da água bruta para usos na usina.

Visando atender a solicitação expressa na Licença Prévia 013/2001 (item 5.18), foram realizados monitoramento biológico dos efeitos do lançamento de efluente sobre o ecossistema do rio Macaé, este monitoramento foi efetuado utilizando-se, como bioindicadores, os organismos integrantes da fauna bentônica. A escolha deste segmento da biota para a análise em enfoque se justifica por aspectos tais como:

- Seu amplo emprego em monitoramentos que visam acessar a qualidade ambiental de corpos de água em diferentes regiões do mundo;

- A baixa mobilidade e capacidade de dispersão dos organismos, notadamente de fases larvais de Odonata, Trichoptera e Ephemeroptera;

- A existência de estudos detalhados sobre estes organismos na bacia do rio Macaé, desenvolvidos por técnicos da Fundação Oswaldo cruz;

A amostragem da fauna de bentos foi realizada conjugando o uso de busca-fundos manuais com peneiras, objetivando reduzir a perda de informações derivada da seletividade dos métodos de coleta.

As unidades de amostragem são demarcadas com vistas a traçar um gradiente longitudinal a montante e a jusante do ponto de lançamento, bem como incorporar um transecto horizontal partindo do ponto de lançamento às margens adjacentes.

Os dados reunidos em campo são tratados utilizando-se modelos de riqueza, diversidade e equitabilidade. Observação de padrões espaciais e temporais de estruturação das comunidades bentônicas deverão ser feitas mediante o uso de métodos de comparação multivariada. 
Durante a construção e operação da usina são monitorados os seguintes parâmetros: Turbidez; pH; Temperatura da amostra; Temperatura do ar; Sólidos Totais Suspensos; Sólidos Totais; Óleos e graxas; Oxigênio dissolvido; Cor; DBO; $\mathrm{Al} ; \mathrm{Fe} ; \mathrm{HCO}_{3} ; \mathrm{CO}_{3} ; \mathrm{Cl} ; \mathrm{SO}_{4} ; \mathrm{NO}_{3} ; \mathrm{SiO}_{2} ; \mathrm{NH}_{4} ; \mathrm{Ca} ; \mathrm{Mg} ; \mathrm{Na} ; \mathrm{K} ; \mathrm{PO}_{4}$.

Na fase de construção, óleos e graxas, turbidez e sólidos suspensos foram monitorados mensalmente, e os demais parâmetros não foram monitorados nesta fase.

Na fase de operação, alguns parâmetros são medidos continuamente, tais como o pH, oxigênio dissolvido e temperatura. Sólidos suspensos, óleos e graxas e cloro serão amostrados diariamente e os demais parâmetros mensalmente.

Os métodos de coleta e análise das águas serão os especificados nas normas aprovadas pelo Instituto Nacional de Metrologia, Normalização e Qualidade Industrial - INMETRO ou, na ausência delas, no "Methods for the Examination of Water e Wastemater” - APHA-AWWA-WPCF, última edição.

As análises dos parâmetros que demandassem ensaios de laboratório foram realizadas por laboratórios contratados, desde que credenciados pelo órgão ambiental.

Os dados obtidos neste programa serão disponibilizados para INEA, submetidos à DIAG -Divisão de Qualidade da Água para análise e aprovação, em relatórios semestrais, com dados fornecidos em meio digital, de acordo com modelo de formulário a ser fornecido pelo INEA, contendo indicações de métodos laboratoriais e análise e interpretação dos dados.

Quanto ao monitoramento biológico, o programa contou com uma etapa de caracterização “back ground”, a ser realizada antes do início da operação da usina.

A partir do início da operação foram realizadas campanhas semestrais durante os primeiros dois anos caracterizando o período de estiagem e o período de cheias de cada ano. A partir do terceiro ano as campanhas passaram a ter frequência anual na medida em que já se dispunha de uma base de conhecimento sobre as variabilidades atribuídas à sazonalidade, que permitirá a interpretação dos resultados das campanhas anuais. Estas foram realizadas ao longo dos três anos 
seguintes de forma constatar-se a eventual ocorrência de alterações de longo prazo.

\subsection{5}

\section{Qualidade dos efluentes}

A UTE Macaé possui sistemas de tratamento de efluentes (efluentes industriais e sanitários). Esses sistemas foram projetados de modo que a qualidade dos efluentes esteja de acordo com o previsto na legislação em vigor, de forma a não alterar a qualidade das águas do Rio Macaé.

Para verificar se estes sistemas estão operando adequadamente, e para atender ao Programa de Autocontrole de Efluentes Líquidos do INEA (PROCON AGUA), onde é necessário realizar o autocontrole da qualidade dos efluentes.

A CECA emitiu a DZ-942.R-7 Diretriz do Programa de Autocontrole de Efluentes Líquidos - PROCON Água, com critérios e procedimentos para o auto monitoramento da qualidade dos efluentes das atividades efetiva ou potencialmente poluidoras.

Com base em tais diretrizes são previstos os seguintes procedimentos:

- Amostras dos efluentes da usina (efluentes sanitários, efluentes do sistema de desmineralização, blowdown da torre de refrigeração e efluente líquido combinado) serão tomadas, para verificação da adequação aos limites preconizados na resolução CONAMA 20/86 (artigo 21), e confronto com as condições verificadas no corpo hídrico a jusante do lançamento.

- A coleta deve ser efetuada de acordo com a MF-402 - Método de coleta de amostra em efluentes líquidos industriais.

- Os resultados do monitoramento são apresentados ao INEA por intermédio do Relatório de Acompanhamento de Efluentes Líquidos - RAE, conforme a já referida DZ. 
- Este relatório contém: identificação e localização da empresa, dados do corpo receptor, identificação do sistema de tratamento, período do relatório, resultados das análises, empresa que realizou as análises, nome e cargo do responsável pelo relatório, dados da vazão dos efluentes e parâmetros achados fora dos padrões e medidas adotadas para correção. A DZ 942 traz um modelo do RAE que deve ser seguido.

- Os efluentes líquidos tratados são lançados no rio Macaé, de acordo com a Norma Técnica NT-202 R-10, obedecendo os padrões citados na referida norma.

De acordo com a já mencionada DZ, a frequência do monitoramento é função da vazão de efluentes e para vazões entre 1.000 e 10.000 m3/dia, caso da UTE Macaé, a frequência é conforme apresentado a seguir:

Tabela 6 - Frequência de Medições e de Coleta de Amostras de Efluentes

\begin{tabular}{|c|c|}
\hline PARÂMETROS & FREQÜÊNCIA \\
\hline Vazão $\left(\mathrm{m}^{3} /\right.$ dia $)$ & 1.000 à $10.000 \mathrm{~m}^{3} / \mathrm{dia}$ \\
\hline $\mathrm{pH}^{(1)}$ & Diária \\
\hline Temperatura & Diária \\
\hline Condutividade & Diária \\
\hline Cloretos & Semanal \\
\hline Resíduos Sedimentáveis & Semanal \\
\hline Resíduo não filtrável total & Semanal \\
\hline Resíduo não filtrável volátil & Semanal \\
\hline Oxigênio Dissolvido & Diária \\
\hline Öleos e Graxas & Semanal \\
\hline DBO (afluente/efluente) & Quinzenal \\
\hline DQO (afluente/efluente) & Semanal \\
\hline \begin{tabular}{|l|} 
Metais \\
\end{tabular} & Semanal \\
\hline Indice de Fenóis & Semanal \\
\hline Fenóis & Semanal \\
\hline Sulfetos & Semanal \\
\hline Fluoreto & Semanal \\
\hline Sulfato & Quinzenal \\
\hline Surfactantes & Duas vezes por semana \\
\hline Cloro Residual & Diária \\
\hline Nitrogênio Amoniacal & Semanal \\
\hline Nitrogênio Nitrito & Semanal \\
\hline Nitrogênio Total & Semanal \\
\hline Fósforo Total & Quinzenal \\
\hline Compostos Orgânicos Tóxicos & Quinzenal \\
\hline Toxicidade & Mensal \\
\hline Coliformes Fecais & Semanal \\
\hline $\begin{array}{l}\text { Número mínimo de porções de } \\
\text { amostras em efluentes contínuos }\end{array}$ & 8 \\
\hline
\end{tabular}

(1) controle nos afluentes e nos efluentes 
Uma análise inicial dos efluentes gerados na usina foi realizado, de modo a verificar a necessidade da análise dos parâmetros acima citados, uma vez que alguns deles não deverão ser afetados pela operação da UTE Macaé. Neste caso os parâmetros que se mostrarem não influenciáveis ou não estiverem presentes em níveis detectáveis nos efluentes da usina foram informados ao INEA e determinado, de comum acordo com aquela instituição a exclusão dos mesmos do conjunto de parâmetros monitorados neste programa, passando a ser acompanhados unicamente na qualidade da água do rio Macaé através do Monitoramento de Qualidade da Água.

\subsection{6}

\section{Solos e águas subterrâneas}

O vazamento de óleo e outros produtos nas áreas de estocagem e oficinas poderiam contaminar o solo e as águas subterrâneas. Embora considerado como possibilidade remota, visto a área ser de uso agrícola, usos anteriores da área podem ter deixado resíduos e contaminantes no solo e/ou na água subterrânea.

Deste modo, o Programa de Monitoramento de Solos e Águas Subterrâneas visou controlar e evitar a contaminação de aquífero e do solo existente nas áreas próximas de depósitos e/ou áreas de manipulação de produtos químicos, tais como as áreas próximas de almoxarifados e das estações de tratamento de água e de efluentes.

Foram realizadas durante as obras de implantação da usina, uma campanha de prospecção de solos e água subterrânea, para averiguar a existência de contaminantes no solo.

Nesta campanha foram realizadas as seguintes atividades:

- execução de furos de sondagem;

- medição do teor de compostos orgânicos voláteis;

- coleta de 4 amostras de solo, em pontos significativos do terreno; 
- coleta de 4 amostras de água subterrânea em pontos significativos do terreno;

- análise das amostras para hidrocarbonetos, principais metais poluentes, compostos orgânicos voláteis, compostos orgânicos semi-voláteis, hidrocarbonetos poliaromáticos e PCB.

Durante a fase de operação da usina, o monitoramento seguiu esta mesma metodologia, considerando-se os locais previstos para a instalação das oficinas de manutenção e área de estocagem de insumos (produtos químicos). As campanhas deverão ser realizadas a cada 5 anos após a entrada em operação da planta.

\subsection{7}

\section{Processos Erosivos}

Além das medidas de controle de erosão incorporadas no projeto de terraplanagem, a detecção de áreas sujeitas a processo erosivos será realizada através de inspeções visuais rotineiras da área do empreendimento, registrando-se sistematicamente os aspectos observados. Essas inspeções terão frequência mensal.

No caso da detecção do início de processos erosivos, os seguintes procedimentos serão adotados com vistas a deter o avanço do processo e recuperar as áreas atingidas.

\subsection{8}

\section{Resíduos Sólidos}

Os resíduos sólidos gerados na UTE Macaé Merchant são provenientes de dois sistemas :

- Tratamento de Água para uso Industrial

- Tratamento de Esgoto Sanitário 
Durante o processo de tratamento de água para uso industrial é produzido lodo. Trata-se assim de lodo comum e típico de sistemas de abastecimento público de água, cuja composição varia ao longo do ano, conforme as características da água bruta captada.

Outro tipo de lodo produzido decorre do tratamento de esgotos domésticos,que pela pequena população da usina, 60 funcionários, é de pouca relevância. Todo o lodo produzido terá uma gestão adequada para atendimento da legislação aplicada

Existe ainda a geração de determinadas quantidades de borras oleosas e óleos lubrificantes usados.

Todos os resíduos são inventariados e classificados nos termos da Res. CONAMA 06/88 e normas da ABNT e estaduais associadas, no Plano de estão de Resíduos Sólidos a ser apresentado por ocasião da solicitação da Licença de operação. Os resíduos serão armazenados em containers de $30 \mathrm{~m} 3$ e serão removidos, semanalmente, por empresa credenciada e autorizada pela FEEMA a recolher este tipo de resíduo. Em alguns casos, como as resinas gastas e os óleos lubrificantes usados, os fornecedores terão a responsabilidade pelo transporte e pela reciclagem, nos termos dos contratos respectivos de suprimento. 


\section{LIÇÕES APRENDIDAS}

\section{1}

\section{Lições aprendidas durante a fase da construção da UTE Macaé}

A experiência e a oportunidade de participar em um projeto dessa magnitude com um cronograma muito apertado é única.

Como já vimos alguns limites que foram definidos através das legislações e parâmetros já citados no capítulo 4, principalmente nas áreas inerentes a Efluentes Líquidos, Captação de água, Emissões Atmosféricas, Qualidade do Ar, Níveis de Ruído, Resíduos, entre outros.

O projeto começa ser realizado, considerando referências técnicas das melhores tecnologias e atendimento de todas as legislações e requisitos básicos gerados com órgãos ou instituições nacionais e/ou internacionais, principalmente os aspectos ambientais, além disso, é extremamente importante levar em conta todos os stakeholders envolvidos direta ou indiretamente no processo, em todas as fases.

O primeiro desafio encontrado pela empresa, foi definir a locação mais adequada do projeto, para que fossem viáveis o fornecimento de todos os insumos necessários para a geração de energia térmica, verificado a disponibilização dos insumos necessários, foi realizado o EIA, estudo de impacto ambiental e respectivamente o RIMA, relatório de impacto ao meio ambiente , em uma linguagem mais fácil, para que a audiência pública necessária, fosse realizada com a participação de todos os stakeholders, principalmente as comunidades vizinhas e ONG's, organizações não governamentais, etc. Para que fossem emitidas as licenças prévia , de instalação e de operação durante os períodos adequados até a entrada em operação do projeto.

Já com o local definido e avaliação de impactos ambientais realizados, consequentemente a licença prévia foi liberada, assim a empresa começou a 
mobilização para realização do projeto detalhado. Encontrava-se um fator inesperado. A empresa havia comprado uma gleba de terra em que o proprietário havia se responsabilizado em reassentar os moradores em outras áreas e/ou fazendas que ele havia, e também garantiria o trabalho para a maioria dos moradores que trabalhavam com ele em outro ramo de atividade , construção civil.

$\mathrm{Na}$ verdade este passivo acabou impactando de maneira significativa no projeto, onde foram verificadas que mais de 12 famílias ainda habitavam na região, lembrando que a região era, e, é de suma importância devido a necessidade de amortecimento acústico, pois a usina térmica foi instalada em uma área rural. Este é um outro tema que deve ser observado pelas empresas. A grande maioria dos projetos acabam sendo implantados em áreas rurais, daí a necessidade de se antecipar buscando a mudança da categoria de zoneamento da área onde ocorrerá a instalação do projeto, junto aos órgãos competentes.

O que pode ser explicitado é que devido o compromisso social da empresa e as necessidades de atendimento as diretrizes do braço privado do banco mundial, IFC. Essas famílias foram reassentadas em imóveis próprios, convênios firmados com a municipalidade para fornecimento de mão de obra de professores e outros serviços necessários a comunidade, além de área específica para desenvolverem a monocultura, criação de porcos, etc.

Após os contratempos previstos anteriormente citados, a obra de construção civil iniciou-se com a terraplenagem, onde foram utilizados motoscrapers equipamentos que tem como final , corte, transporte e reaterro de solo em pequenas distâncias, surgindo um dos grandes problemas de qualquer obra de terrapleanagem, previstos no projeto de mitigação, projeto ambiental de construção, controle de emissões de poeiras fugitivas, através do PAC ( Programa Ambiental de Construção ), que previa o controle da qualidade do ar, a realidade têm que ser exposta de maneira a pararmos de considerar algo que é propriamente difícil de operacionalizar, todo e qualquer programa que envolva tal atividade deverá considerar que as áreas de rodagem principais somente devem ter o controle de poeiras através de utilização de caminhões pipa. É muito difícil de 
operacionalizar em uma área tão extensa ter controle de poeiras, se tornando inviável.

As emissões de escapamentos de veículos foram previstas, entretanto devemos lembrar de geradores de eletricidade a diesel, compressores e outros que também queimam combustíveis fósseis e impactam de maneira significativa se não tiverem manutenção adequada.

Um ponto importante a ser tratado quando falamos de utilização de equipamentos pesados, os equipamentos requerem limpeza e manutenção contínua. No plano ambiental de construção e monitoramento ambiental deverá sempre considerar avaliação de solo/água subterrânea antecipada à instalação de área de lubrificação, manutenção e lavagem dos equipamentos. Por mais cuidado que a empresa tenha, poderá haver contaminação dos solos/águas subterrâneas, este item foi considerado de maneira abrangente no programa de monitoramento, item referente ao Programa de Monitoramento de solos e águas subterrâneas e que deve ser considerado através de avaliação em conjunta e prévia, principalmente no que se refere a áreas de manuseio de combustíveis fósseis, além de produtos químicos. Lembrando que a experiência demonstra que a maioria das ocorrências acontecem por falta de manutenção dos equipamentos e falta de treinamento e qualificação para manusear os materiais perigosos.

As dificuldades de manutenção, a possibilidade de serem danificados e a provável contaminação dos poços piezométricos durante a fase da construção deixam claro a necessidade de estabelecimento de fases específicas para aplicação do Programa de Monitoramente solos e águas subterrâneas, sendo uma fase específica para construção e outra para operação.

A rotina de construção segue, sendo importante ressaltar que os grandes empreendimentos de hoje em dia estão cada vez mais acelerados e que o segredo para o sucesso de qualquer projeto se chama planejamento.

Alguns itens devem ser trabalhados pelos órgãos competentes, durante grandes projetos a quantidade de resíduos gerados, sólidos e líquidos que devem ser destinados de maneira eficaz e atendendo a legislação em vigência. Entretanto durante a construção pudemos identificar que apesar da coleta seletiva realizada 
no projeto, não foi possível dispor os resíduos de maneira segregada fora dos limítrofes do empreendimento. Macaé na oportunidade só dispunha de um lixão, aonde todas as empresas de coleta de resíduos da região destinavam os resíduos coletados de diversas empresas. A dificuldade de encontrar empresas interessadas por materiais que poderiam ser reciclados e/ou reaproveitados durante o empreendimento é um fato que deve ser considerado antecipadamente em qualquer projeto com grande geração de resíduos.

Os esgotos gerados durante a construção foram destinados por empresa contratada através de caminhões limpa fossa para área de destinação aprovada pela prefeitura de Macaé. Observa-se que não haviam áreas aprovados pelo órgão estadual de meio ambiente.

A preocupação com a drenagem das áreas de trabalho foram implementadas de acordo com o projeto de maneira a estarem bem estabilizadas e com controle de erosão implementado.

As questões relacionadas a ruídos e vibrações originadas só foram sentidas pelas pessoas dos arredores (na gleba de terra da empreendedora) quando da realização de limpeza das tubulações instaladas, que eram comunicadas previamente pelo empreendedor.

Durante a fase de construção do projeto, a logística do empreendimento foi considerado um dos itens mais importantes, entretanto o alto risco da rodovia BR101, única acesso para o projeto. Considerado um dos maiores riscos de acidentes relacionados ao projeto, por diversas vezes foram utilizados recursos do empreendimento para prestar auxílio à acidentes na rodovia supra citada.

A medida que os trabalhos de construção iam ficando prontos, se iniciava uma das fases mais complicada devido as diversas atividades acontecendo em paralelo. Iniciava-se o comissionamento dos primeiros grupos geradores, fase de testes operacionais para início da produção de energia. Esta fase foi atendida com sucesso, entretanto deve ser uma fase de maior controle e acompanhamento da área de SMS. 
É neste momento que se descobre falhas básicas de projeto, como: equipamento inadequado, equipamento mal especificado, dificuldades na manutenção, falhas nos sistemas, principalmente devido a falta de avaliação ergonômica em projeto, além de verificação de potenciais riscos de acidentes e contaminação.

Durante os processos de conformidade, existem processos que devem ser exaustivos, tais como: necessidade de um controle de qualidade e qualidade assegurada bem rigoroso.

A Análise de risco do projeto deve ser mais específica e profunda. Há e deve sempre haver a necessidade específica de um HAZOP ou PHA das unidades separadamente e também de um HAZOP ou PHA considerando todos as diversas áreas da USINA, considerando os processos em funcionamento de maneira conjunta.

É interessante lembrar que a maioria das empresas começam a operar ainda em fase de testes, principalmente por haver compromissos com os clientes e ou com a própria corporação para que o retorno do investimento se inicie rapidamente.

Durante a fase final de testes e início de operações é extremamente difícil para qualquer empresa garantir e atender em 100\% os limites de emissão atmosférica, emissão de efluentes, etc.

Deve-se trabalhar em conjunto, isto é o empreendedor e o órgão licenciador para que haja uma tolerância por um período de tempo, desde que os impactos sejam avaliados e verificados que não serão de efeitos irreversíveis.

Lembrando que o sistema de gestão ambiental durante a construção, atendia todas as condicionantes definidas nas licenças prévia e de instalação, legislação ambiental pertinente e expectativas da corporação.

Com certeza o EMMP, programa de monitoramento e gerenciamento ambiental foi uma excelente diretriz para o sucesso durante a construção, lembrando que era parte integrante do EMMP, uma gestão de contratadas rigorosa, que contemplava um anexo contratual de SMS ( Saúde , Meio Ambiente 
e Segurança ), em que as empresas contratadas seguiram fielmente, no caso de não estar em consonância , cláusulas de penalidade foram inclusas. Parte integrante do anexo são as condicionantes ambientais obrigatórias e definidas pelo órgão ambiental, diretrizes e política do empreendedor, diretrizes dos órgãos financiadores do empreendimento e principalmente uma estrutura de gestão ambiental efetiva que se alinhe com a do empreendedor. Contratando uma empresa sólida e com um histórico que se alinhe com às expectativas do empreendedor.

\section{2}

\section{Lições Aprendidas durante a fase de operação}

Durante a fase operacional, o nível de organização é maior, não há mais tanta rotatividade de mão de obra como na implantação do projeto. Isto é muito importante, pois o sistema de gestão ambiental envolve uma série de programas, objetivos e metas que só conseguem ser cumpridas com a capacitação e envolvimento de todos os níveis da organização, como já citado.

O sistema de gestão ambiental foi formatado com as seguintes prioridades, atendimento aos requisitos à seguir:

- Licença Operacional emitida pela extinta FEEMA, hoje INEA;

- Diretrizes Ambientais do IFC- braço privado do Banco Mundial ;

- Legislação Ambiental ( Federal, Estadual, Municipal )

- Normas e Padrões Internos da empreendedora

Com isso foram colocados em prática os Programas de Monitoramento já citados no item 6.4 .

No início da operação, o programa de monitoramento de emissão e nível de ruído foram monitorados de maneira eficaz, realizando as medições previstas, em conformidade com a frequência semestral e atendendo os limites estabelecidos pela NBR 10151, citada no CONAMA 01/90 
O procedimento para o programa em discussão só deve contemplar avaliação inicial na fase de elaboração do EIA e outra avaliação para confirmar que os estudos de níveis de ruído realizados durante esse período estão de acordo com as medições com a planta em operação de plena carga.

Contemplando itens previstos na NBR 10151:

Nível sonoro medido em $\mathrm{dB}(\mathrm{A})$; duração do ruído ou, para níveis variáveis, sua distribuição estatística; condição de operação da fonte de ruído e características climáticas reinantes durante as medições (temperatura , direção e velocidade dos ventos); hora de ocorrência do ruído e medições; nível sonoro corrigido, nível de ruído de fundo medido; valor do critério de ruído com as correções para o período (diurno e noturno) e zona (residencial , industrial , etc.) croquis com os pontos de medição.

É importante entender o conceito do nível de critério de avaliação NCA foi atendido, conforme tabela seguir:

Tabela 7 - Nível de critério de avaliação NCA para ambientes externos, em dB(A)

\begin{tabular}{|l|c|c|}
\hline \multicolumn{1}{|c|}{ Tipos de áreas } & Diurno & Noturno \\
\hline Áreas de sítios e fazendas & 40 & 35 \\
\hline Área estritamente residencial urbana ou de hospitais ou de escolas & 50 & 45 \\
\hline Área mista, predominantemente residencial & 55 & 50 \\
\hline Área mista, com vocação comercial e administrativa & 60 & 55 \\
\hline Área mista, com vocação recreacional & 65 & 55 \\
\hline Área predominantemente industrial & 70 & 60 \\
\hline
\end{tabular}

Com certeza um dos itens mais discutidos na viabilização do projeto. Durante a operação, o controle rigoroso através do equipamento CEMS Continous Emission Monitoring System, onde foi instalado uma unidade para o conjunto de 4 turbinas, que contemplava os seguintes equipamentos:

- Medidores de Gases

- Medidores de particulado 
- Calibradores automáticos dos aparelhos

- Sistema automático de limpeza de filtros;

- Condicionadores de amostra de gases;

- Saídas digitais e analógicas para salas de controle do queimador de gases

- Sistema de Alarme ajustáveis;

- Coleta e armazenagem automática de dados;

- Sistema de alarme geral dos dados

A experiência demonstrou que por ser uma nova tecnologia e um equipamento específico, que até então não existia no Brasil, foi muito difícil colocar o equipamento em operação, devido a falta de peças sobressalentes e de mão de obra qualificada. Até que a equipe de manutenção e operação da unidade dominasse o sistema para que o mesmo se tornasse uma grande ferramenta de apoio a uma operação adequada e dentro dos parâmetros ambientais, transcorrendo um bom período de tempo.

Considerando que esse monitoramento contínuo era instalado em uma chaminé a cada grupo de quatro grupo geradores, fornecidos a tempo real para a central de dados de qualidade de ar do INEA os seguintes parâmetros: $\mathrm{O}_{2}$, NOx e $\mathrm{CO}$, as demais chaminés foram amostradas com equipamentos portáteis, procedimento que sempre foi realizado por empresas contratadas, que na maioria das vezes não tinham muita experiência nesse tipo de empreendimento. Outro fator que sempre foi um complicador era a necessidade de ter os grupos geradores em funcionamento para realização dos testes. Quando a UTE Macaé ficou pronta, os reservatórios das hidrelétricas já estavam cheios e em condições de geração. As térmicas assumiram o papel que já anteriormente era previsto de energia reserva ou emergencial, baseado no custo de geração do MWh.

As medições foram realizadas de acordo com o cronograma previsto na licença operacional: Primeira Campanha de cada 3 chaminés de cada grupo : 02 meses após o início da operação, 03 meses após a primeira campanha, 06 meses 
após a segunda campanha , quarta campanha e as seguintes a cada 6 meses . Prazos esses que foram atendidos com muita dificuldade e muita negociação com o INEA.

Entretanto não era contemplado um procedimento de monitoramento para verificação de qualidade assegurada das chaminés que utilizavam o CEMS. Importante definir que em projetos de queima de combustíveis fósseis seja instalado o monitoramento contínuo em todas as chaminés, evitando exposição continuada de amostragens em campo.

Alguns desvios aconteceram e acontecem, apesar do ajuste das máquinas através de uma operação e manutenção adequada, verificado através do CEMS no momento de partida das máquinas.

A empresa atendeu o estabelecido pelo PROCON AR- Programa de Autocontrole de Emissões para a Atmosfera, estabelecido pela DZ 545 de 07/08/86, que é parte integrante do Sistema de Licenciamento de Atividades Poluidoras - SLAP concedida para a UTE Macaé.

A captação de água do rio Macaé e a gestão de efluentes industriais é muito mais que um projeto, e sim um gerenciamento hídrico constante , onde foi verificado que os resultados das diversas análises realizadas ao longo dos anos decorridos desde que a usina entrou em operação são favoráveis , isto é não geraram nenhum impacto no corpo hídrico em questão.

O plano de gerenciamento de resíduos foi implementado e todos os resíduos foram destinados de maneira adequada e dentro dos padrões definidos pela legislação em vigência, mesmo que investimentos elevados.

Muito mais que atendimento a legislação propriamente foram utilizadas como base a norma ISO 14001 e a diretriz OHSAS 18001, por conseguinte sequência descrita abaixo:

Diagnóstico através de empresa de consultoria foi realizado e verificados os pontos fortes, assim como as oportunidades de melhorias. 
Pontos importantes que devem ainda ser lembrados é de extrema relevância a integração e envolvimento das diversas áreas técnicas e das responsabilidades bem distribuídas entre as equipes multidisciplinares.

Antes disso, foi realizada a fase mais importante do projeto, o compromisso de todos os colaboradores da liderança da companhia, do escritório central e da unidade em discussão.

Onde uma reunião com a alta liderança e todo o corpo gerencial da unidade se comprometeram em desenvolver os itens referentes aos padrões apresentados.

O diagnóstico da empresa de consultoria, foram verificados pontos positivos já implementados. As oportunidades de melhoria foram apresentadas:

-Política, objetivos, metas e programas.

-Sistemática de controle e atualização de documentos e registros

-Identificação de aspectos e impactos / perigos e riscos

-Levantamento de Legislação pertinente e monitoramento contínuo das normas relacionadas

-Criação de procedimentos gerenciais

Na sequência foi estabelecida a política e disseminada.

Iniciado o planejamento para identificação de fator de risco, avaliação e controle de risco, onde foram definidos as metodologias (definição de todas premissas adequadas aos temas de Meio ambiente e saúde e segurança ocupacional. Realização de projeto piloto em áreas distintas e pré- determinadas. Identificação dos AA( aspectos ambientais)/IA( impactos ambientais )/RO ( riscos operacionais )/Emergências com IA (impactos ambientais), Avaliação dos AA/IA/RO/Emergências com IA, Lista Mestra dos AA/IA significativos e com a classificação dos RO, disponibilização das listas mestras pertinentes a cada área da empresa, onde foram alinhados os requisitos legais com os impactos e riscos significativos, montando um banco de dados alinhado e capaz de manter a 
atualização da legislação e divulgação para todas as áreas. É importante enfatizar que os requisitos relacionados ao financiamento do projeto, também foram e devem ser considerados, como outros requisitos.

Uma lista mestra da legislação e outros requisitos de SMS foram disponibilizados para as diversas áreas da empresa.

Durante a revisão de objetivos e metas propostas, foi verificado que a empresa os tinha, baseados no BSC (balanced score card) entretanto não eram metas específicas para cada nível da organização.

Um ponto crítico identificado foi a oficialização das responsabilidades e autoridades para o sistema de gestão integrado, assim como o representante da alta administração, também reconhecido como facilitador.

Durante os quesitos de treinamento, conscientização e competência, foi verificado a importância da integração com diversos departamento para que seja elaborado uma matriz de treinamento coerente com os padrões e que mantenha o foco de desenvolvimento de carreira e profissional dentro da empresa. É muito importante a eficácia do treinamento. A capacitação dos empregados e o conhecimento disseminado através de um programa de sensibilização e motivação em SMS.

A grande maioria das empresas realmente realizam as diretrizes acima descritas , entretanto o compromisso deve ser estendido a todas as empresas contratadas

Independente da atividade a ser realizada, do nível ou função do profissional, um dos mais eficientes treinamentos nos procedimentos "On the job training”, uma das ferramentas de sucesso aplicadas durante a operação.

A definição de canais e competências para a comunicação com as partes interessadas, ou afetadas pelo sistema de gestão integrada, como exemplo , todos devem saber e reconhecer o representante da alta administração, assim como serem atualizados das mudanças em políticas , e/ou procedimentos, foi realizada com muito empenho e sucesso. 
A comunicação fluiu através de um plano de comunicação eficiente que englobe não só a comunicação interna quanto a externa.

A arquitetura de documentação foi montada, entretanto a padronização em todas as áreas não foi realizada, o caráter de controle de documentos foi melhorada com um facilitador e com um sistema informatizado.

A elaboração dos controles operacionais para AA/IA indiretos, aplicando medidas de controle cabíveis foram estabelecidas. Os critérios para a seleção e avaliação de fornecedores/parceiros, atendendo os requisitos de SMS, definindose os diferentes critérios para os diferentes tipos de fornecedores que atuavam dentro e fora da planta.

Um ponto interessante quando falamos em plano de emergência é que deve ser estabelecido previamente, o plano de emergência deve ser estabelecido contemplando não pode simplesmente contemplar requisitos ambientais e sim todas as hipóteses de acidentes identificadas na análise de Risco, assim foi feito e considerando principalmente o gerenciamento de materiais perigosos. Simulados eram constantes, treinamentos referente ao assunto, assim como análise crítica eram realizadas, com uma excelente estrutura de resposta preparada e montada, com diversos recursos, no tocante a monitoramento e medição de desempenho podemos ressaltar:

- Definição de itens críticos para o SGI (sistema de gestão integrado)

- Definição de critérios para avaliar o desempenho ambiental e ocupacional da Empresa (definição de indicadores reativos + pró ativos)

- (definição de indicadores gerenciais/alta administração + operacionais)

- Definição de programas e rotinas para os monitoramentos do SIG

- Definição da lista de equipamentos críticos para o SIG (MA, Higiene, Médica, etc..) 
- Critérios para calibração/confirmação metrológica

- Critérios de avaliação de fornecedores e validação de resultados de medições/analises executadas por terceiros.

- Procedimento/rotina para avaliação periódica de conformidade legal (rotinas áreas + auditorias)

As não conformidades, acidentes, incidentes, assim como ações preventivas e corretivas foram tratadas através de procedimentos, considerando análise de qualquer ocorrência ou observação levantada e registrada.

O critério de identificação, manutenção e disposição de registros foiram implementados com sucesso.

Dentro dos processos de auditoria foram identificadas algumas práticas realizadas pela empresa, como BPR (Best practices Review), Auditoria integrada realizada pela corporação da empresa , focada em processo e SMS principalmente. Programas específicos de auditoria internas, foram implementadas e calendários aprovados.

A análise crítica da administração foi estabelecida, importante salientar que a norma e diretriz utilizada serviram de espinha dorsal para implementação de um sistema que muito além, utilizando o sistema EMIS - Sistema de gestão de SMS 


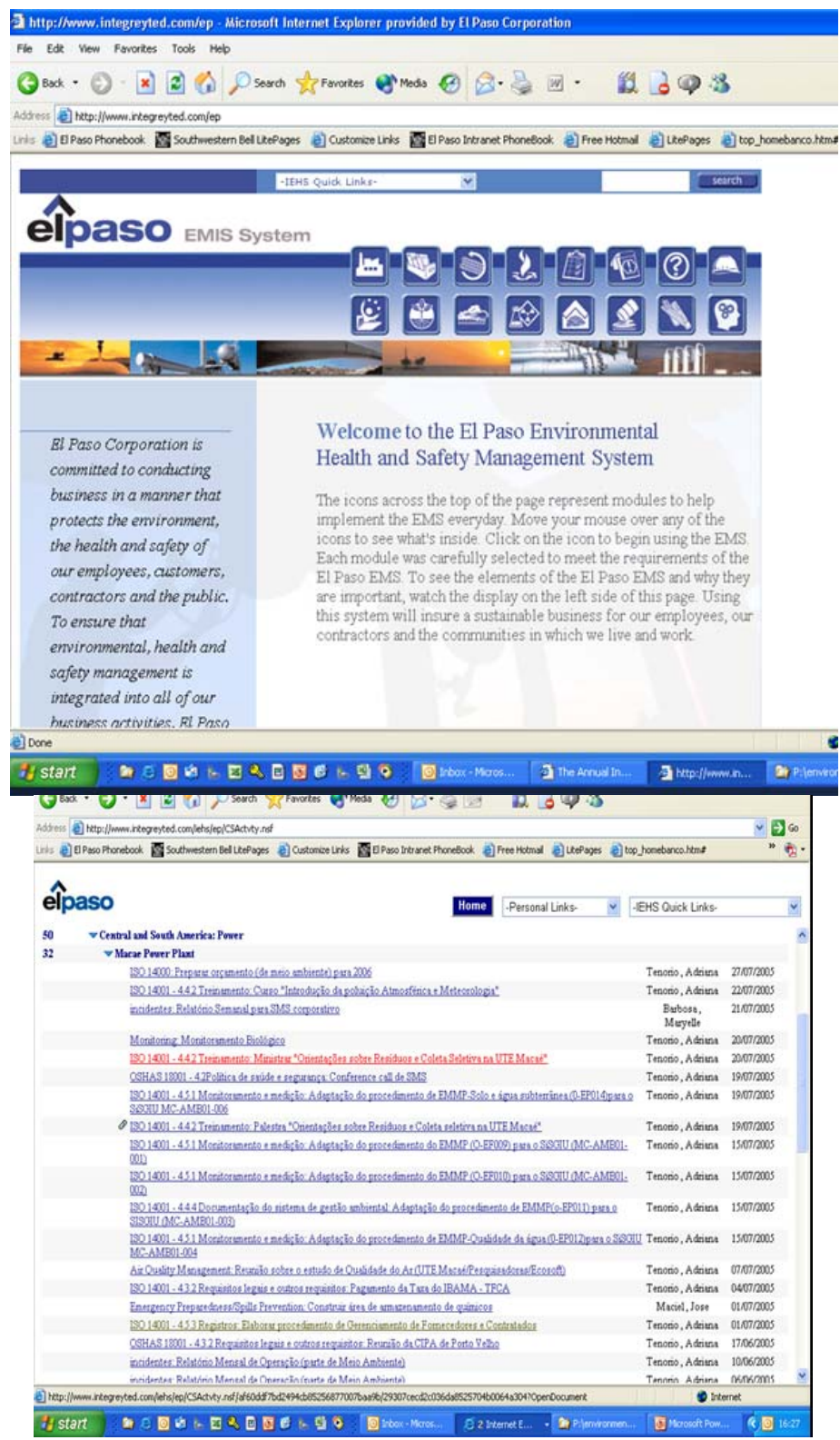

Figura 18 - EMIS: Environmental Health and Safety Management System (Sistema de Gerenciamento de SMS)

A figura abaixo mostra o layout do sistema sisgiu para onde os procedimento do EMMP e EMIS foram adaptados 


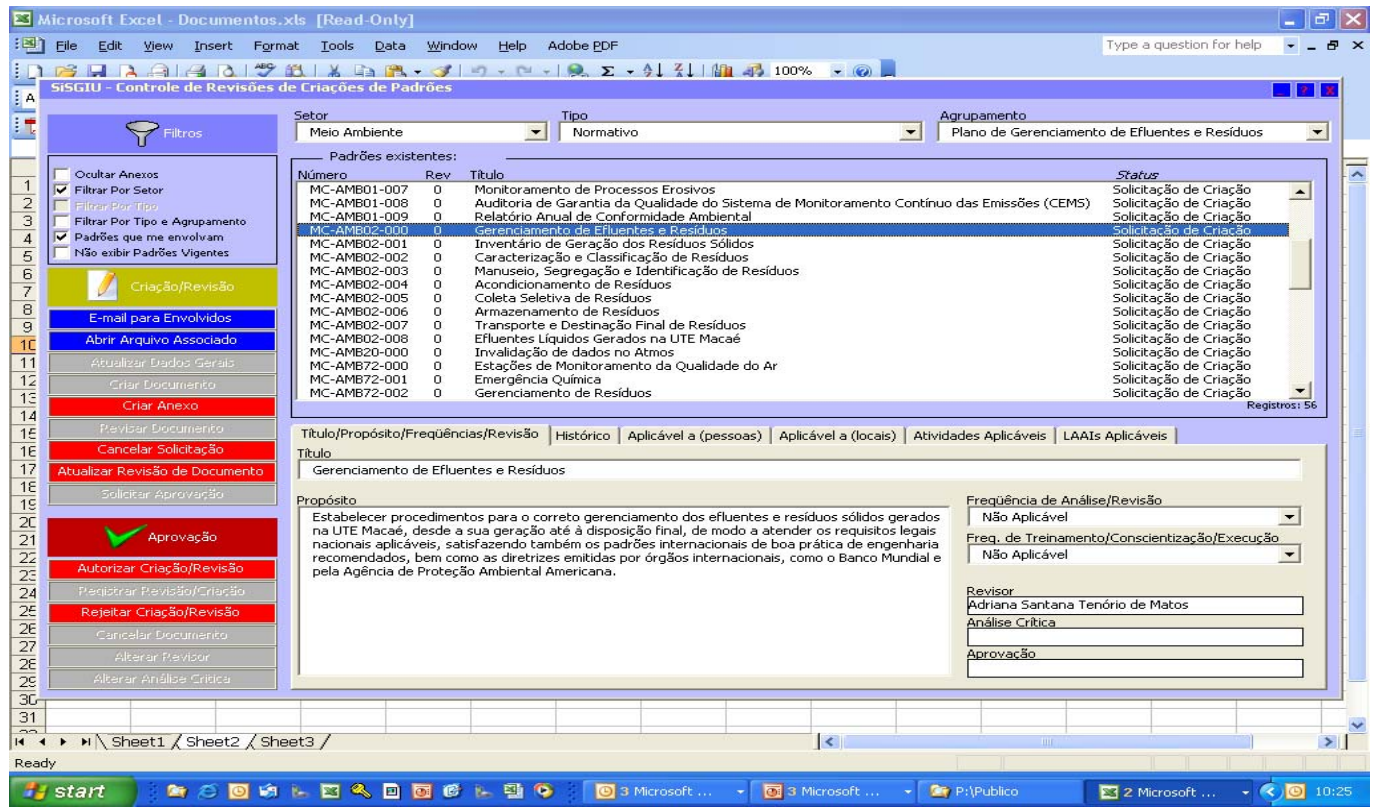

Figura 19 - SISGIU - Sistema Simplificado de Gestão de Informações da Usina

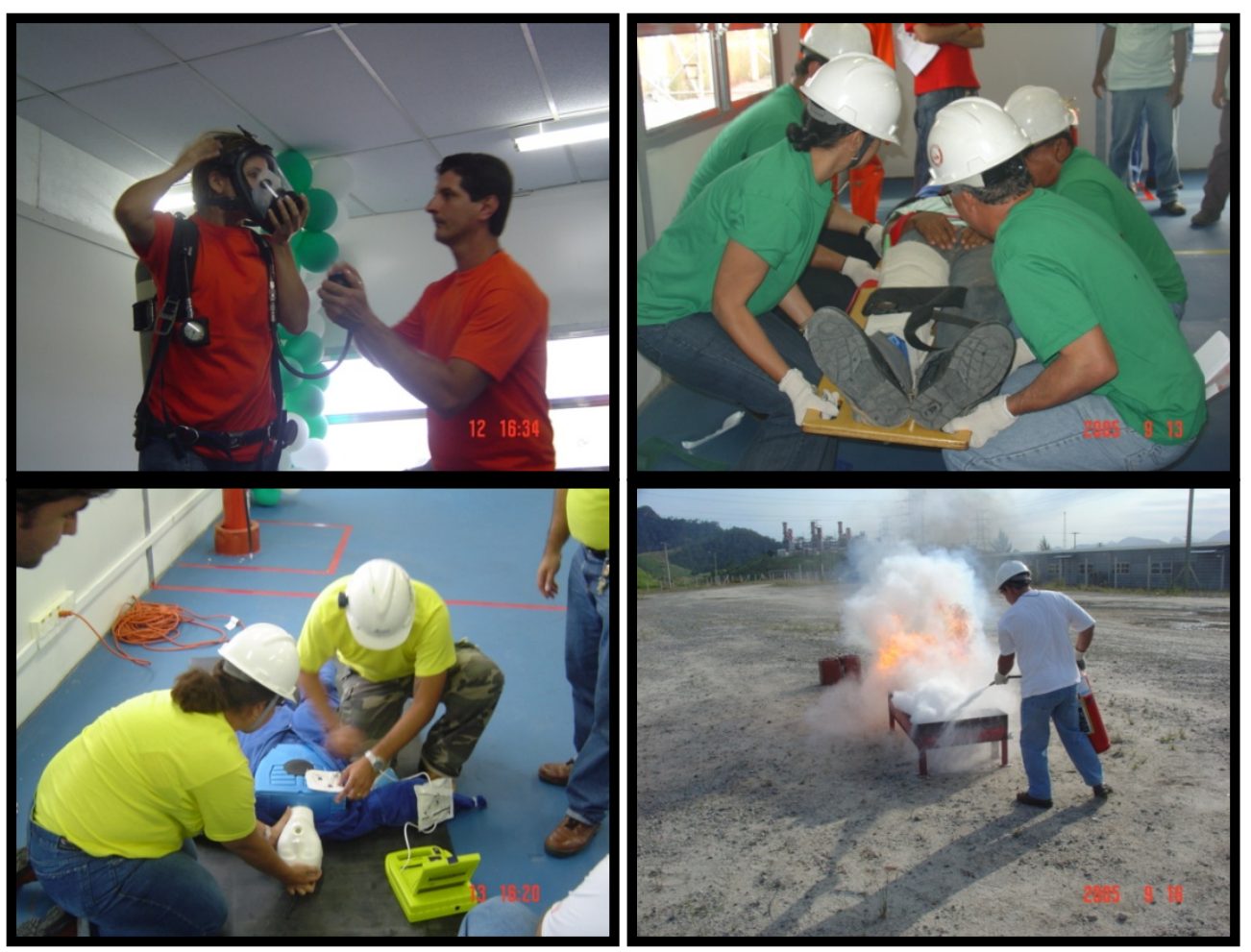

Figura 20 - Treinamentos de Brigada de Emergência 


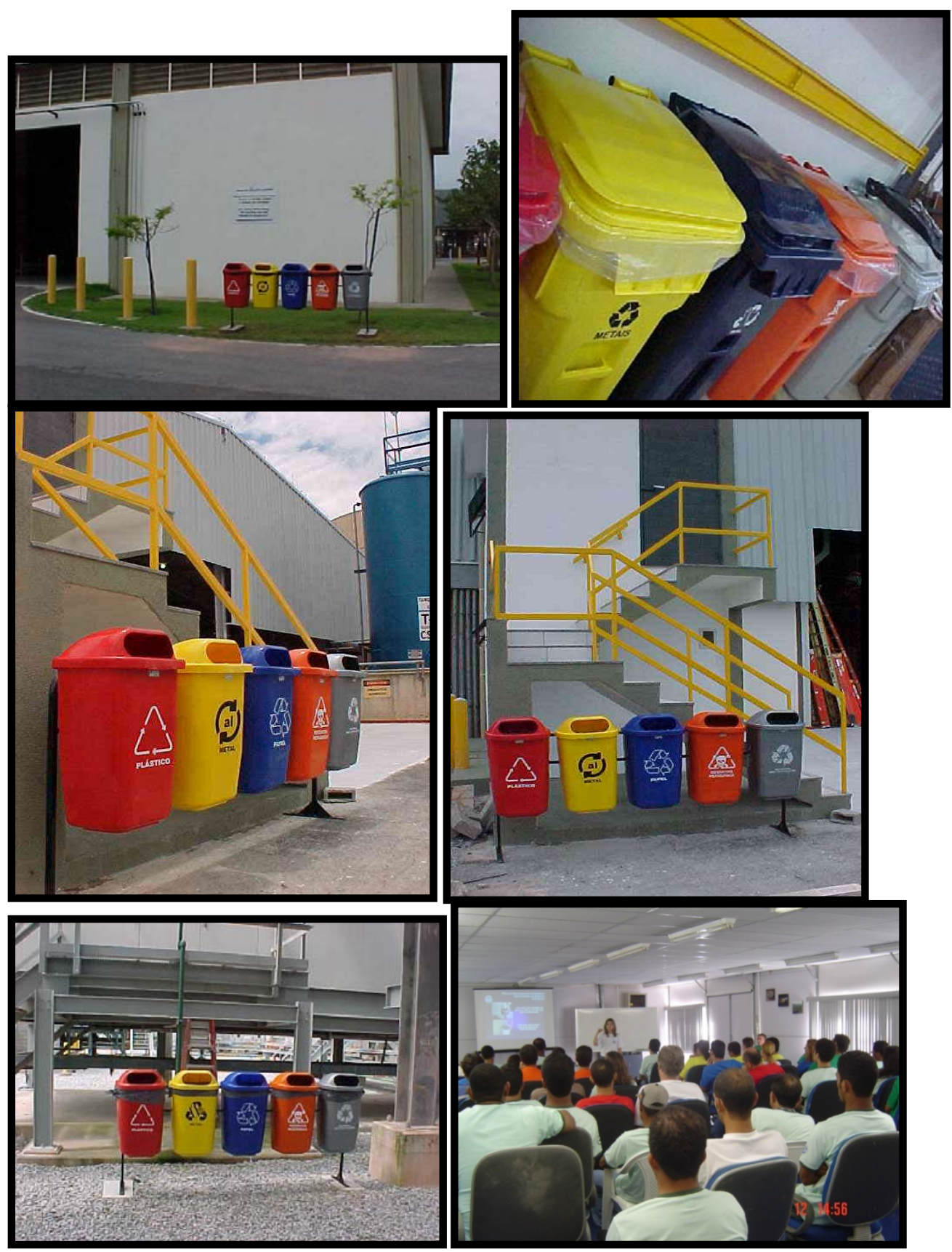

Figura 21 - Plano de Gerenciamento de Resíduos.

Todo investimento em gestão integrada de SMS é retornado através de resultados expressivos, pois com a melhora da organização e controle do empreendimento, é possível verificar oportunidades de melhorias de desempenho na produção e processo, gerando um retorno factível e realístico ao acionista. 


\section{8 \\ CONCLUSÃO}

Um dos alicerces para crescimento de um País se chama infraestrutura. Observamos que um dos mais importantes fatores a ser considerado na instalação de qualquer empreendimento, imprescindível, se chama "Energia”.

Produzir energia de forma sustentável é o grande desafio das grandes nações em desenvolvimento.

A gestão adequada para uma melhoria da eficiência energética brasileira e a definição de uma matriz energética atendendo os melhores princípios de sustentabilidade, sem que haja impacto no atendimento da crescente demanda energética para novos investimentos no País, é um grande desafio, principalmente quando existem políticas contrárias ao interesse dos países em desenvolvimento.

A consideração das especificidades de cada região, assim como a necessidade de melhoria dos indicadores de desenvolvimento humano é um fator crucial nas tomadas de decisão para a definição de locação de um empreendimento.

A necessidade de os empreendedores estarem alinhados e atendendo as expectativas dos stakeholders no que diz respeito aos indicadores de sustentabilidade, compilados através de fatores econômicos, sociais e ambientais fazem com que as empresas melhorem a cada dia o seu sistema de gestão de novos projetos.

O grande avanço ocorrido das novas políticas e diretrizes ainda não fazem com que o Brasil seja um País tranquilo quando o assunto é setor elétrico, já que os atrasos são frequentes nas entregas de construções de Usinas Térmicas. Poderíamos sim, estar atravessando uma crise nos dias de hoje. E isso só não aconteceu graças ao desaquecimento da economia. Térmicas que deveriam ter entrado em operação entre janeiro de 2010 e janeiro de 2013, para que a oferta de energia fosse aumentada não foram entregues e não atenderam o cronograma, 
fazendo com que a ONS, Operadora Nacional do Sistema mexesse em seu planejamento.

O atraso na entrega de parques eólicos também expõe as fraquezas da matriz energética do País. É importante ainda lembrar que os reservatórios estão abaixo dos níveis normais. A expectativa de chuvas fizeram com que o sistema nacional acionasse as energias de térmicas. E se não tivéssemos usinas térmicas?

O Brasil avançou no conhecimento da tecnologia de térmicas, ao contrário da situação em 2001, quando do apagão elétrico no País, onde pouco se conhecia sobre essa tecnologia. Isso trazia insegurança para os órgãos e agências ambientais. Além de receio por diversos stakeholders, visto que era uma tecnologia pouco difundida no Brasil.

Novos regulamentos sobre emissões atmosféricas, termos de referência para elaboração de avaliação de impactos ambientais foram criados por diversas agências ambientais estaduais fazendo com que os estudos fossem direcionados e qualificados, baseados nas experiências vividas pelas térmicas pioneiras implantadas no sudeste do Brasil.

A gestão ambiental da UTE Macaé atendeu todos os parâmetros e regulamentos nacionais e internacionais em vigência. Como toda experiência, alguns itens específicos poderiam ser melhorados, entretanto não se pode falar da gestão ambiental do projeto sem levar em consideração o contexto socioeconômico do País naquele período, que passava por um racionamento de energia e com o valor de tarifas de energia nas alturas.

A térmica de ciclo combinado conforme mencionado nesta tese, é uma tecnologia que pode se reaproveitar energia proveniente das emissões da queima do gás natural para geração de vapor em uma caldeira de recuperação, gerando energia por outra turbina a vapor. Entretanto a urgência de implantação de um projeto que atendesse as demandas energéticas do país impactou na decisão por uma tecnologia de ciclo simples, com menor aproveitamento de energia.

A interlocução do departamento ambiental com o departamento de engenharia foi interessante, entretanto se deparava com a dificuldade de culturas 
diferentes e de uma empresa gerenciadora que não entendia das demandas e especificidades da região. Fato este que não gerou impactos significativos, pois desde o começo do projeto, sabia-se da necessidade de financiamento por parte do banco mundial, que na época, diga-se ano de 2001, já tinha parâmetros ambientais restritivos específicos para construção de projetos de usinas térmicas no mundo, para viabilização do empréstimo, facilitando o trabalho do departamento de SMS, mesmo com a falta de regulamentos brasileiros.

A experiência em todas as fases do projeto fez com que o autor pudesse identificar que a inserção dos aspectos ambientais o mais cedo possível durante a concepção do projeto a ser instalado, faz com que a empresa possa ter um ganho muito grande, não só ambiental, quanto social e econômico.

Após a análise das lições aprendidas nos diversos períodos do empreendimento, uma proposta para os grandes líderes e gestores de projeto foi estabelecida no sentido de auxiliar em melhores resultados e não ter surpresas durante a instalação de projetos.

Para que deste modo, a gestão ambiental, seja estabelecida através de uma cultura e valores que suportem um futuro adequado e de acordo com as expectativas dos stakeholders em todas as fases: concepção e viabilidade do projeto, projeto conceitual básico, projeto detalhado e construção e operação do projeto.

Com isso, sim podemos dizer que a empresa tem o compromisso com a sustentabilidade. 


\section{REFERÊNCIAS}

ANDRADE, R. O. B., CARVALHO, A.B., TACHIZAWA, T. Gestão ambiental - enfoque estratégico aplicado ao desenvolvimento sustentável. $2^{\mathrm{a}}$. ed. São Paulo: Makron Books, 2002.

ANEEL. Agência Nacional de Energia Elétrica. Atlas de Energia Elétrica do Brasil, ANEEL, Brasília/DF, 2005.

APOENA. Associação em defesa do rio Paraná , Afluentes e Mata Ciliar,http://apoena.org.br/artigos-detalhe.php?cod=207, Acesso em nov.2011

BAJAY, S. V.; WALTER, A. C. S.; FERREIRA, A. L. relatório técnico - fase 5: otimização das práticas de planejamento e dos procedimentos regulatórios envolvidos no dimensionamento; construção e operação de usinas termelétricas. Campinas: UNICAMP, 2000.

BRASIL. Lei $\mathbf{n}^{0}$ 10.848, de 15 de março de 2004. Dispõe sobre a comercialização de energia elétrica, altera as Leis $\mathrm{n}^{\mathrm{0s}} 5.655$, de 20 de maio de 1971, 8.631, de 4 de março de 1993, 9.074, de 7 de julho de 1995, 9.427, de 26 de dezembro de 1996, 9.478, de 6 de agosto de 1997, 9.648, de 27 de maio de 1998, 9.991, de 24 de julho de 2000, 10.438, de 26 de abril de 2002, e dá outras providências. Disponível em: <http://www.planalto.gov.br/ccivil_03/_ato20042006/2004/lei/110.848.htm>, Acesso em ago. 2011.

BRASIL. Ministério de Minas e Energia. Balanço Energético Nacional (BEM), 2010. Disponível em: <https://ben.epe.gov.br/>, Acesso em mar. 2011b.

BRASIL. Geração de Energia - Situação Atual. Disponível em: $<$ http://www.ana.gov.br/pnrh/DOCUMENTOS/5textos/6-2energia.pdf>, Acesso em marc. 2011c.

BRASIL. Lei $\mathbf{N}^{0}$. 6.938/1981. Dispõe sobre a Política Nacional do Meio Ambiente, seus fins e mecanismos de formulação e aplicação, e dá outras providências.

Disponível em: <http://www.planalto.gov.br/ccivil_03/leis/L6938.htm>, Acesso em ago. 2011d.

BURSZTYN, M; et al. Formulação e Implementação de Políticas Públicas Compatíveis com os Princípios do Desenvolvimento Sustentável definidos na Agenda 21. Disponível em: <www.mma.gov.br/port/SE/agen21/21_bras.html>. Acesso ago. 2011.

CAMPOS L. M. S. \& LERÍPIO A. A. Qualidade Ambiental e ISO 14000. Apostila Curso ministrado pelo EJEP/EPS/UFSC. Florianópolis, 9-10 mai, 2007.

CARDOSO DA CUNHA, Antonio Renato. Direito administrativo. Net jurídica. Disponível 
<http://www.netjuridica.com.br/licoes/intervencao_estado_propriedade.htm>. Acesso em ago. 2011.

CLERECUZIO, C. e LAMMERS, P. Front End Loading. Myths and Misconceptions. Technical Paper. Disponível em : http://www.mustangeng.com. Acesso em 15 de janeiro de 2012.

COMPANHIA VALE DO RIO DOCE. Curso de Mineração - Módulo 4. Documentação interna. Rio de Janeiro: Companhia Vale do Rio Doce, 2007.

D'AVIGNON, Alexandre. Normas ambientais ISO 14000: como podem influenciar sua empresa. Rio de Janeiro: CNI, DAMPI, 1996.

DEL RIO, V. \& OLIVEIRA, L. Percepção ambiental: a experiência brasileira. $4^{\mathrm{a}}$ ed. São Paulo: Studio Nobel. 2004.

DONAIRE, D. Gestão Ambiental na Empresa. 2a edição. São Paulo: Editora Atlas, 1999.

DONAIRE, D. Gestão ambiental na empresa. São Paulo: Editora Atlas, 1995.

DUARTE, Marcos D. Caracterização da Rotulagem Ambiental de Produtos, dissertação de mestrado apresentada ao curso de Engenharia da Produção da Universidade Federal de Santa Catarina, 2007.

ELETROBRÁS.PROCEL.Disponível

em: http://www.eletrobras.com/ELB/main.asp?ViewID=\%7BD81425AF-257E-44E98B0F-1F885CD35D6D\%7D , pesquisado ago 2011

FERREIRA, A.; WALTER, C. S.; BAJAY, S. V. Otimização da praticas de procedimentos e planejamento regulatório envolvidos no dimensionamento, construção e operação de usinas termelétricas. Relatório fase 5, convênio Agência Nacional de Energia Elétrica - FUNCAMP. Campinas: NIPE, UNICAMP, 2000.

GASNET, 2008. Disponível em: < http://www.gasnet.com.br>. Acesso em 11 nov.. 2011

GENERAL ELECTRIC, 2011. Disponível em: < http://www.geflexbility.com>. Acesso em 05 nov. 2011

GONÇALVEZ, L. C. Gestão Ambiental em meios de Hospedagens. São Paulo, Aleph, 2004.

GRAJEW, Oded. O que é responsabilidade social. Simpósio Nacional de Negócios e Responsabilidade Social (SINAL 99), Ribeirão Preto: Instituto Ethos de Empresas e Responsabilidade Social, Novembro. 1999

GUERREIRO, A., LOPES J., QUEIROZ R., et al.Aspectos da geração térmica a gás natural no Brasil. In: CONGRESSO BRASILEIRO DE ENERGIA, XI., 2006, Rio de Janeiro 
KONDO, E. K. Projeto de Prospecção Tecnológica: C\&T para o Brasil 2010. Termo de Referência preliminar para discussão. Brasília: CNPq/Superintendência de Planejamento, 2007.

LEITE, A. D. A Energia do Brasil. 2a . ed., Rio de Janeiro: Elsevier, 2007.

LIBANORI, A. A aplicação de mecanismos econômicos na política de controle da poluição. Tese de Mestrado apresentada à Pontifícia Universidade Católica (PUC) de São Paulo, 1990.

LISBOA, Henrique de Melo. Controle da Poluição Atmosférica - Cap. 3 Efeitos da Poluição Atmosférica - ENS/UFSC. Montreal Primeira versão - Agosto 2007.

LONGARAY, André Andrade et al. Como elaborar trabalhos monográficos em contabilidade: teoria e prática. São Paulo: Atlas, 2003.

MAGRINI, Alessandra; ROSA, Luiz Pinguelli; XAVIER, Edna Elias; SANTOS, Marco Aurélio. Monitoração de Emissões de Gases de Efeito Estufa em Usinas Termelétricas no Brasil - Fase de Diagnóstico. Programa de Planejamento Energético - PPE/COPPE/UFRJ, 2001.

MAIMON, D. ISO 14001 - Passo a Passo da Implantação nas Pequenas e Médias Empresas. Rio de Janeiro: Qualitymark Editora Ltda., 1999.

MILARÉ, Edis. Direito do ambiente. $7^{\mathrm{a}}$ ed. São Paulo: Revista dos Tribunais, 2011.

MOISÉS, Marcos Aurélio Martins. Benefícios da cogeração a gás natural para o Estado de São Paulo. Dissertação de Mestrado em Engenharia de Processos Químicos e Bioquímicos - Escola de Engenharia Mauá do Centro Universitário do Instituto Mauá de Tecnologia, CEUM-EEM, São Caetano do Sul, SP, 2007.

MOTA, The Direct Use of Coal - Prospects and Problems of Production and Combustion - Office of Technology Assessment, USA. 1997.

NBR ISO 14001. Sistemas da gestão ambiental - Requisitos com orientações para uso. Associação Brasileira de Normas Técnicas - ABNT. 2004.

OLIVEIRA, M. A. L. A Empresa do Novo Milênio. Exame. São Paulo, p. 10, 12 jan. 2000.

PALHANO, B. N. Setor elétrico e meio ambiente: a institucionalização da “questão ambiental”. 2001. Tese (Doutorado em Planejamento Urbano e Regional) - Instituto de Pesquisa e Planejamento Urbano e Regional, Universidade Federal do Rio de Janeiro, Rio de Janeiro, 2001.

PASINI DA COSTA, Ana Cristina. Setor elétrico e o risco ambiental. Disponível em <http://www.canalenergia.com.br>. Acesso em ago. 2011.

PERES, L. A. P., NOGUEIRA, L. A. H., TORRES, G. L., 2000. Impactos das Emissões Atmosféricas Provocadas por Geradores Diesel em Estudos de Fontes 
de Energia no Meio Rural. In AGRENER 2000, $3^{\circ}$ Encontro de Energia no Meio Rural, NIPE/UNICAMP, SBEA, Campinas.

PHILIPPI Jr., Arlindo. O Impacto da Capacitação em Gestão Ambiental. Faculdade de Saúde Pública. Departamento de Saúde Ambiental. Tese de LivreDocência. Faculdade de Saúde Pública da USP. 2002.

PIRES Lorena Fornari de Ary. GESTÃO AMBIENTAL DA IMPLANTAÇÃO DE SISTEMAS DE TRANSMISSÃO DE ENERGIA ELÉTRICA ESTUDO DE CASO: INTERLIGAÇÃO NORTE/SUL I. Dissertação submetida ao Programa de Pós-Graduação em Ciência Ambiental da Universidade Federal Fluminense, como requisito parcial para obtenção do título de Mestre. UFF, +Niteroi/RJ, 2005.

PÖYRY, Jaakko. Estudos de impactos ambientais. Companhia Termelétrica do Planalto Paulista. Paulínia/SP - 13-011-Ejpe-1800, 2008.

SAUER, I. L., org. A Reconstrução do Setor Elétrico Brasileiro. São Paulo, Paz e Terra, 2003.

SEVA F. A. O. , BERMANN, Célio. Energia para o Desenvolvimento ... Enfim Social, Anais, VII Congresso Brasileiro de Energia, Rio de Janeiro, outubro 2006. GIL, Antônio Carlos. Como Elaborar Projetos de Pesquisa. São Paulo: Atlas, 2002.

TACHIZAWA, T. Gestão Ambiental e Responsabilidade Social Corporativa: estratégias de negócios focada na realidade brasileira. São Paulo: Atlas, 2002.

TORRES, H. D. G. A demografia do risco ambiental. População e Meio Ambiente: Debates e Desafios. H. d. G. Torres and H. S. M. Costa. São Paulo, Editora Senac: 53-73. 2006.

VALLE, C. E. Como se Preparar Para as Normas ISO 14000 - Qualidade Ambiental - O Desafio de Ser Competitivo Protegendo o Meio Ambiente. São Paulo: Pioneira Administração e Negócios \& ABIMAQ/SINDIMAQ, 1996.

WALTER, A. C. S., BAJAY, S. V. \& FERREIRA, A. L. Relatório Técnico da Fase 6: Proposição de eliminação de barreiras e formulação de políticas de fomento, com os instrumentos regulatórios associados, à geração distribuída de energia elétrica no Brasil, sobretudo com fontes renováveis e plantas de cogeração, Projeto de Pesquisa sobre "Integração entre as Regulações Técnico-Econômica e Ambiental do Setor Elétrico Brasileiro (Meta 1), Convênio ANEEL/FUNCAMP sobre "Regulação de Mercados de Energia Elétrica", Núcleo Interdisciplinar de Planejamento Energético - NIPE, UNICAMP, outubro 2000, 55p. 